University at Buffalo School of Law

Digital Commons @ University at Buffalo School of Law

\title{
Liberty, Community and the Constitutional Structure of Political Influence: A Reconsideration of the Right to Vote
}

James A. Gardner

University at Buffalo School of Law

Follow this and additional works at: https://digitalcommons.law.buffalo.edu/journal_articles

Part of the American Politics Commons, and the Election Law Commons

\section{Recommended Citation}

James A. Gardner, Liberty, Community and the Constitutional Structure of Political Influence: A Reconsideration of the Right to Vote, 145 U. Pa. L. Rev. 893 (1997).

Available at: https://digitalcommons.law.buffalo.edu/journal_articles/241

\section{C) ${ }_{\text {COPYRIGHT }}^{\text {N }}$}

This Article is brought to you for free and open access by the Faculty Scholarship at Digital Commons @ University at Buffalo School of Law. It has been accepted for inclusion in Journal Articles by an authorized administrator of Digital Commons @ University at Buffalo School of Law. For more information, please contact lawscholar@buffalo.edu. 


\title{
LIBERTY, COMMUNITY AND THE CONSTITUTIONAL STRUCTURE OF POLITICAL INFLUENCE: A RECONSIDERATION OF THE RIGHT TO VOTE
}

\author{
JAMES A. GARDNER $†$
}

\section{INTRODUCTION}

The meaning of the right to vote is among the most contentious, highly charged questions in all of contemporary law. To a degree unmatched in other areas, judicial and legislative actions affecting the right to vote may have immediate and decisive impacts on the nation's public life. Political fortunes may be won or lost and political power gained or forfeited depending on the resolution of such questions. The Supreme Court's decisions last term invalidating legislative districts in North Carolina ${ }^{1}$ and Texas, ${ }^{2}$ for example, upended at a stroke residents' settled expectations and threw local politics in those states into an uproar. ${ }^{3}$ The Court's recent rejection of state-imposed term limits for members of Congress ${ }^{4}$ potentially had even fartherreaching consequences not only for the identity of federal officeholders but for the quality of representation itself. ${ }^{5}$ Furthermore, there is nothing like a presidential election campaign to bring home the extent to which voting rights issues such as party formation, ballot access and campaign finance bear on the nation's immediate political future.

Yet the making or breaking of political fortunes is only part of the

† Professor of Law, Western New England College School of Law; B.A. 1980, Yale University; J.D. 1984, University of Chicago Law School. Thanks to Jack Chin, Joan Mahoney, Jay Mootz and Monte Piliawsky for helpful comments and suggestions. Thanks also to Dean Joan Mahoney and Western New England College School of Law for financial support, and to Lauren Galliker for research assistance.

1 See Shaw v. Hunt, 116 S. Ct. 1894 (1996).

${ }^{2}$ See Bush v. Vera, 116 S. Ct. 1941 (1996).

'See Linda Greenhouse, High Court Voids Race-Based Plans for Redistricting, N.Y. TIMES, June 14, 1996, at Al.

${ }^{1}$ See U.S. Term Limits, Inc. v. Thornton, 115 S. Ct. 1842 (1995).

5 The Arkansas law struck down in Thornton, for example, stated in its preamble that "elected officials who remain in office too long become preoccupied with reelection and ignore their duties as representatives of the people." Id. at 1845 (quoting ARK. CONST. amend. CXXIII, preamble). 
picture. Many of the most visible contemporary voting rights controversies concern the proper interpretation of the Voting Rights Act especially whether the Act confers on groups or individuals an affirmative right to representation. These issues make for a particularly incendiary mix, combining as they do two of the things about which Americans feel most strongly: democracy and race.

In an area of such significance and volatility one might hope the courts would be, if not controversial, at least clear. Alas, few areas of constitutional law are as maddeningly confused and starkly contradictory as the law governing the right to vote. As Justice Harlan once observed, the Court's explanation of the right to vote has been singularly unhelpful. The Court speaks, he complained, "in conclusory terms of 'debasement' or 'dilution' of the 'voting power' or 'representation' of citizens without explanation of what these concepts are. The answers are hardly apparent ...."?

Yet any confusion sown by the Court's failure to speak pales in comparison to the confusion caused by what it has actually said. In a contradiction unparalleled in constitutional law, the Court has said both that the Constitution "[u]ndeniably" protects the right to vote in state and federal elections ${ }^{8}$ and that the right to vote "is not a constitutionally protected right." ${ }^{3}$ According to the Court, the right to vote is the most fundamental of rights "because [it is] preservative of all rights" ${ }^{\prime 10}$ and its abridgment must survive strict scrutiny; ${ }^{11}$ yet the Court has also insisted that "the Constitution ... does not confer the right of suffrage upon any one." ${ }^{12}$ Less contradictory, but equally puzzling, is the Court's insistence on analyzing voting rights claims under the Equal Protection Clause when the right to vote in a republic seems a far better candidate for substantive than for relative forms of analysis. In addition, the meaning of the Court's revolutionary announcement in Reynolds $v$. Sims that the Constitution requires "fair and effective representation"13 remains frustratingly elusive after more than thirty

${ }^{6} 42$ U.S.C. $\$ 1973 b$ (1994).

${ }^{7}$ Whitcomb v. Chavis, 403 U.S. 124, 167 (1971) (Harlan, J., concurring).

${ }^{8}$ Reynolds v. Sims, 377 U.S. 533, 554 (1964).

${ }^{9}$ San Antonio Indep. Sch. Dist. No. 15 v. Rodriguez, 411 U.S. 1, 35 n.78 (1973).

${ }^{10}$ Yick Wo v. Hopkins, 118 U.S. 356, 370 (1886).

"See, e.g., Kramer v. Union Free Sch. Dist., 395 U.S. 621, 626 (1969); Harper v. Virginia Bd. of Elections, 383 U.S. 663,670 (1966).

${ }_{12}$ Minor v. Happersett, 88 U.S. (2I Wall.) 162, 178 (1874); accord Rodriguez v. Popular Democratic Party, 457 U.S. 1, 9 (1982).

13 Reynolds, 377 U.S. at 565-66. 
years. $^{14}$

The degree of public confusion over the content of the right to vote is reflected in the enormous variety of claims made in its name. Litigants have claimed that the right to vote requires that the franchise be extended to particular persons ${ }^{15}$ at particular times; ${ }^{16}$ that certain offices be filled by election; ${ }^{17}$ that elected officials represent equal numbers of people; ${ }^{18}$ that district lines be drawn in particular ways; ${ }^{19}$ that officials be elected from single-member districts; ${ }^{20}$ that certain candidates be permitted to run for office, ${ }^{21}$ or that their names be placed on the ballot; ${ }^{22}$ that write-in voting be permitted; ${ }^{2 s}$ and that the candidates be listed on the ballot in a certain order. ${ }^{24}$ The passage of the Voting Rights Act, particularly the 1982 amendments, ${ }^{25}$ expanded the instances in which the right to vote has been invoked to include statutory claims that election districts must be drawn to allow certain groups to control electoral outcomes; ${ }^{26}$ that districts be drawn to avoid certain shapes; ${ }^{27}$ and that legislators draw district lines according to some criteria and not others. ${ }^{28}$ If these litigation trends have made

1 See, e.g., Samuel Issacharoff, Supreme Court Destabilization of Single-Member Districts, 1995 U. CHI. LEGAL F. 205; Sanford Levinson, Gerrymandering and the Brooding Omnipresence of Proportional Representation: Why Won't It Go Away?, 33 UCLA L. REV. 257 (1985); Peter H. Schuck, The Thickest Thicket: Partisan Gerrymandering and Judicial Regulation of Politics, 87 COLUM. L. REV. 1325 (1987).

${ }^{15}$ See Richardson v. Ramirez, 418 U.S. 24, 26-27 (1974) (claiming that rights should be extended to convicted felons); Harper v. Virginia Bd. of Elections, 383 U.S. 663, 665 (1966) (claiming that the right to vote in state elections may not constitutionally be conditioned upon the payment of a tax or fee); Lassiter v. Northampton County Bd. of Elections, 360 U.S. 45, 45 (1959) (claiming that a state-imposed literacy test is an unconstitutional prerequisite to the right to vote).

${ }^{16}$ See Dunn v. Blumstein, 405 U.S. 330 (1972); Carrington v. Rash, 380 U.S. 89 (1965).

${ }_{17}$ See Rodriguez, 457 U.S. 1 (1982); Fortson v. Morris, 385 U.S. 231 (1966).

${ }^{18}$ See Reynolds v. Sims, 377 U.S. 533-(1964); Wesberry v. Sanders, 376 U.S. 1 (1964).

${ }^{10}$ See Davis v. Bandemer, 478 U.S. 109 (1980); Gomillion v. Lightfoot, 364 U.S. 339 (1960).

${ }^{20}$ See White v. Regester, 412 U.S. 755 (1973).

21 See Clements v. Fashing, 457 U.S. 957 (1982).

${ }^{22}$ See Anderson v. Celebrezze, 460 U.S. 780 (1983); Williams v. Rhodes, 393 U.S. 23 (1968).

${ }^{23}$ See Burdick v. Takushi, 504 U.S. 428 (1992).

24 See McLain v. Meier, 637 F.2d 1159 (8th Cir. 1980).

${ }^{25}$ Voting Rights Act Amendments of 1982, Pub. L. No. 97-205, 96 Stat. 131.

${ }^{20}$ See Thornburg v. Gingles, 478 U.S. 30 (1986).

${ }^{27}$ See Shaw v. Reno, 113 S. Ct. 2816 (1993).

${ }^{28}$ See Bush v. Vera, 116 S. Ct. 1941 (1996); Shaw v. Hunt, 116 S. Ct. 1894 (1996); Miller v. Johnson, 115 S. C.t. 2475 (1995). 
anything clear, it is that the right to vote has become so indeterminate that every observer may see in it whatever he or she wishes.

Much of the academic literature on the right to vote seems to share the kind of aimlessness that plagues the dialogue between the courts and litigants. One recurring problem, for example, is a sometimes myopic focus on voting, and on the Voting Rights Act in particular. Some commentators speak about the Voting Rights Act in terms so emphatic and sweeping ${ }^{29}$ as to give the impression that the Act is some kind of quasi-constitution rather than a statute implementing a single provision of the actual Constitution. ${ }^{30}$ As Richard Briffault recently observed, the Act is sometimes spoken of "not as a matter of positive law but as a metaphor for a perfected democracy for minorities." ${ }^{31}$ Yet the significance of the right to vote goes far beyond the issues that arise in the context of statutory rights under the Voting Rights Act. Recent decisions of the Supreme Court intimating that the Court may be poised to significantly limit or strike down altogether section 2 of the Voting Rights Act under the Fourteenth Amendment ${ }^{32}$ serve as a stark reminder that statutory voting rights are necessarily built on a much broader constitutional foundation, a foundation intended to structure the exercise of political influence in American society. ${ }^{33}$ All too often overlooked or taken for granted in

${ }^{29}$ See, e.g., LANI GUINIER, THE TYRANNY OF THE MAJORITY 69, 72 (1994) [hereinafter GUINIER, TYRANNY] (stating that the Voting Rights Act should embody the "transformative vision of politics" of the civil rights movement, and that the Act "anticipates that...blacks ... will produce[] fundamental change in state government" (citation omitted)); Pamela S. Karlan, Undoing the Right Thing: Single-Member Offices and the Voting Rights Act, 77 VA. L. REV. 1, 39 (1991) (hereinafter Karlan, Undoing the Right Thing] (stating that the Voting Rights Act was designed to "bring about a radical realignment of political control"); Pamela S. Karlan, Maps and Misreadings: The Role of Geographic Compactness in Racial Vote Dilution Litigation, 24 HARV. C.R.-C.L. L. REV. 173, 237 (1989) [hereinafter Karlan, Maps and Misreadings] (stating that the Voting Rights Act intended to bring about a "reconstruction of society").

so Congress enacted the Voting Rights Act to enforce the Fifteenth Amendment, using its power under Section 2 of that amendment. See U.S. CoNST. amend XV, § 2; South Carolina v. Katzenbach, 383 U.S. 301, 337 (1966) (upholding numerous provisions of the Voting Rights Act as legitimate exercises of congressional power under Section 2 of the Fifteenth Amendment).

"Richard Briffault, Lani Guinier and the Dilemmas of American Democracy, 95 CoLUM. L. REV. 418, 458 (1995) (reviewing LANI GUINIER, THE TYRANNY OF THE MAJORITY (1994)).

${ }^{32}$ See Miller v. Johnson, 115 S. Ct. 2475 (1995); Shaw v. Reno, 113 S. Ct. 2816 (1993). But see Bush v. Vera, 116 S. Ct. 1941 (1996) (four Justices willing to assume the constitutionality of section 2).

93 See Lani Guinier, [E]racing Democracy: The Voting Rights Cases, 108 HARV. L. REV. 109, 113 (1994) [hereinafter Guinier, [E]racing] (acknowledging that the Voting 
debates over the right to vote is the fact that voting is not an end in itself but merely a means to an end-the end of implementing democracy. ${ }^{34}$ We can hardly expect to figure out what voting-or "fair" voting, ${ }^{35}$ or "meaningful" voting ${ }^{36}$-means without some conception of what voting is for, what purpose it serves within a larger regime of democratic self-government. Such a conception can only be supplied by some theory of democracy itself.

Without this kind of framework, arguments can easily get caught up in the kind of referenceless circles that often plague the academic debates about voting rights. One issue of widespread current interest, for example, is whether the right to vote as manifested in legislative representation is by nature a group right or an individual right, and much ink has been spilled attempting to demonstrate one or the other. ${ }^{37}$ Yet there can be no universal truths here: representation is

Rights Act is "a statute in search of a theory" and that neither the Supreme Court nor Congress has "excavated the principles of democracy in which to locate a group's statutory right to an effective vote").

34 See George Kateb, The Moral Distinctiveness of Representative Democracy, 91 ETHICS 357,357 (1981) (stating that elections are "the fundamental institutions of representative democracy").

${ }^{35}$ Reynolds v. Sims, 377 U.S. 533, 565 (1964).

${ }^{56}$ City of Mobile v. Bolden, 446 U.S. 55, 104 (1980) (Marshall, J., dissenting) (referring to "meaningless" votes).

${ }^{37}$ Compare, e.g., T. Alexander Aleinikoff \& Samuel Issacharoff, Race and Redistricting: Drawing Constitutional Lines After Shaw v. Reno, 92 MicH. L. REV. 588 (1993) (arguing that representation is a group right), Andrea Bierstein, Millennium Approaches: The Future of the Voting Rights Act After Shaw, DeGrandy, and Holder, 46 HASTINGS L.J. 1457 (1995) (group right), Guinier, [E]racing, supra note 33 (group right), and Samuel Issacharoff, Groups and the Right to Vote, 44 EMORY L.J. 869 (1995) (group right), with James U. Blacksher \& Larry T. Menefee, From Reynolds v. Sims to City of Mobile v. Bolden: Have the White Suburbs Commandeered the Fifteenth Amendment?, 34 HASTINGS L.J. 1, 48 (1982) (arguing that representation is an individual right), Katherine Inglis Butler, Affirmative Racial Gerrymandering: Rhetoric and Reality, 26 CUMB. L. REV. 313 (1996) (individual right), Bruce E. Cain, Perspectives on Davis v. Bandemer: Views of the Practitioner, Theorist, and Reformer, in POLITICAL GERRYMANDERING AND THE COURTS 117 (Bernard Grofman ed., 1990) (representation is both a group and an individual right), Pamela S. Karlan, The Rights to Vote: Some Pessimism About Formalism, 71 TEX. L. REV. 1705 (1993) (arguing that the right to vote actually consists of several related rights, some individual and some group), and Martin Shapiro, Gerrymandering, Unfaimess, and the Supreme Court, 33 UCLA L. REV. 227, 232 (1985) (arguing that voting is an individual right and representation is a group right).

The debate over individual versus group rights has also greatly exercised the Court. Although the Court has for many years insisted that the right to vote is solely an individual right, see, e.g., Shaw v. Hunt, 116 S. Ct. 1894 (1996); Reynolds v. Sims, 377 U.S. 533, 561 (1964), in its most recent voting rights case, three Justices explicitly argued that the right to vote is a group right in the context of legislative redistricting. See Bush v. Vera, 116 S. Ct. 1941 (1996) (Souter, J., dissenting). 
not a natural category with fixed, identifiable characteristics. Representation is merely a tool, a mechanism, that can be employed in different ways by different political systems to achieve different goals based on different beliefs about politics and the capabilities of political actors. ${ }^{38}$ Without question, debates about the nature of representation and the meaning of voting are a necessary part of the critical political discourse of any society that has chosen to govern itself democratically. But to debate the specific features of the political system without attending to the broader context of the political choices in which those features are located only loses sight of the ultimate issues and obscures the philosophical and conceptual moves made by the disputants. The result too often is that participants in these debates argue past one another, unable to discern the kind of common ground that might allow them jointly to advance the discussion.

My purpose in this Article is to take a few small steps toward sorting out this confusing, yet vitally important, area of law by examining the justifications that underlie the right to vote itself. In so doing, I hope to lay bare the underlying premises and moves of the parties to the various voting rights debates by setting these debates in a larger context. In the pages that follow, I have adopted two reference points for the examination of voting rights law. First, I examine what voting rights plaintiffs say. What do they actually mean, I ask, when they claim that their right to vote has been infringed? Second, I turn to democratic theory to provide a broader context for the evaluation of these voting rights claims. As it turns out, most voting rights plaintiffs rely rather plainly on one of two well-developed theories of democracy: protective democracy, in which voting is understood as the principal way in which citizens protect their liberties from invasion by the government; and communitarian democracy, in which voting is understood as a manifestation of full membership in society. This information is useful in several important ways. It provides an underlying and potentially unifying theory for voting rights claims; it establishes a conceptual framework for analyzing competing contentions about the right to vote; and it provides some surprising insights into the Supreme Court's otherwise extremely confusing voting rights jurisprudence.

Part I describes protective democracy and communitarian democracy, the two dominant theories of democracy that run throughout

${ }^{33}$ This point was made vividly 30 years ago in HaNNA FenICHEL PITKIN, THE CONCEPT OF REPRESENTATION (1967). 
contemporary voting rights claims. By setting voting rights claims in the context of the larger democratic theories which they implicitly invoke, I hope to show more clearly the relationship among the various claims and the ways in which judicial acceptance or rejection of a voting rights claim can provide useful signals about the democratic theory underlying the courts' rulings.

Part II examines a number of Supreme Court decisions concerning the right to vote in an effort to determine what theory of democracy the Court might be employing. This analysis yields the surprising conclusion that the Court, which habitually speaks about the vote almost exclusively in terms of its liberty-protective properties, has been for the most part distinctly hostile to voting rights claims based on theories of protective democracy. Paradoxically, the Court has been receptive primarily to voting rights claims resting on communitarian grounds. Part II then relies on this insight to offer an explanation for the Court's recently expressed hostility to section 2 of the Voting Rights Act.

Part III sets out some possible explanations for the Court's preference for communitarian-based voting rights claims. I argue, in brief, that the Court dislikes protective democracy-based claims because such claims necessarily force it to decide precisely what political structures the Constitution creates for the effectuation of political influence, something the Court is loath to decide. One reason the Court may wish to avoid these questions is because the answers are likely to be unsatisfactory to contemporary Americans; an unpleasant truth about the Constitution is that it provides scant protection indeed for rights of political influence, including the right to vote.

Communitarian-based theories, on the other hand, offer the Court a way out of this bind because such theories allow it to rely on the mediating concept of tradition. American democratic traditions turn out to be far more rights-protective than the Constitution itself when it comes to rights of political influence. Paradoxically, this divergence allows a basically conservative Court to turn to tradition, not to defeat claims of political right, but to reward them. Part III also examines the ways in which the Court has used equal protection doctrine as a vehicle for asserting what amounts to a substantive theory of communitarian democracy.

Finally, Part IV focuses on the contemporary debate over the existence of a constitutional or statutory right to representation and asks, in light of the pertinent theories of democracy and the Court's voting rights jurisprudence, whether it is possible to construct a plausible 
right-to-representation claim that might survive judicial review. I conclude that such a claim contains significant weaknesses that would make its acceptance by the Court unlikely.

\section{VOTING IN DEMOCRATIC THEORY}

Voting has no intrinsic value. It is not uncommon in some autocratic states for the government to hold elections in which the only candidate on the ballot is the incumbent autocrat. ${ }^{39}$ The rulers then use the results to defend the political legitimacy of the regime. People living in these countries might well be excused for thinking that such a vote is worthless, or worse. This practice reveals starkly that the value of a vote arises from the political and social context in which it occurs.

What then is the value of voting in our society? An extensive body of voting rights law is devoted to the proposition that the denial of the vote-or the denial of an "effective" vote ${ }^{40}$-is presumptively bad. $^{41}$ But why? What exactly is so important about the right to vote that its denial, or the perception of its denial, is so offensive? One way to begin answering this question is by going to the source: the voting rights litigants themselves. Why do they say that voting is so important to them, and just what do they mean when they claim that their right to vote has been infringed?

A detailed review of voting rights claims and judicial responses is deferred until Part II. For now, it is sufficient to observe that over the entire range of cases involving the right to vote in all its manifestations, American voting rights plaintiffs have almost universally made only two kinds of claims to support the contention that their right to vote has been impaired. The first claim is that exclusion in some form or another from the franchise leaves them with an inadequate ability to influence the outcomes of governmental decisionmaking processes. ${ }^{42}$ That is, their inability to vote, or to vote effectively, leaves

${ }^{39}$ The most recent such "election" to make the news was the Iraqi people's overwhelming vote of confidence in Saddam Hussein. See No Surprise in Iraqi Vote, N.Y. TIMES, Oct. 17, 1995, at A10.

${ }^{10}$ See Reynolds v. Sims, 377 U.S. 533, 565 (1964) (referring to "effective" participation and "effective" representation).

11 This presumption is often manifested in the application of strict scrutiny to denials of the right to vote. See, e.g., Kramer v. Union Free Sch. Dist. No. 15, 395 U.S. 621 (1969).

${ }^{42}$ See, e.g., Holt Civic Club v. Tuscaloosa, 439 U.S. 60, 75 (1978); Fortson v. Morris, 385 U.S. 231 (1966); Salyer Land Co. v. Tulare Lake Basin Water Storage Dist., 410 
them politically naked and at the mercy of processes over which they exercise no control. The second claim, by no means incompatible with the first and sometimes asserted simultaneously, is that the denial of the right to vote constitutes an unacceptable form of exclusion from a validating social practice. Exclusion from voting is, in effect, a mark of inferiority, a consignment to a degrading form of secondclass citizenship. ${ }^{43}$

Of course, to identify the harm that voting rights plaintiffs claim to have suffered is only the beginning; we still need some justification for viewing these harms as legally cognizable. Because litigants are often better at describing their injuries than supplying justifications for redressing them, this is a proper point at which to turn for assistance to democratic theory.

Western political thought is well-stocked with diverse theories of democracy, ${ }^{44}$ and we need not search long to find a good fit. For reasons that will soon become apparent, the harms identified above correspond quite well to two kinds of venerable democratic theories: theories of "protective democracy," and theories of what I will call "communitarian democracy." In theories of protective democ-

U.S. 719, 724 (1973); Whitcomb v. Chavis, 403 U.S. 124, 129 (1971); and discussion infra Part II.

${ }^{13}$ See, e.g., Kramer v. Union Free Sch. Dist. No. 15, 395 U.S. 621 (1969); Reynolds, 377 U.S. at 533; Gomillion v. Lightfoot, 364 U.S. 339 (1960); discussion infra Part II.

11 For a good overview, see DAVID Held, MODELS OF DEMOCRACY (1987).

15 There are, of course, many other different theories of democracy that have played a prominent role in the development of democratic thought. For example, a third historically important theory is what C.B. Macpherson calls "developmental democracy." This theory holds that democracy is justified primarily by its effect on the citizenry: active participation in a democratic polity is said to create informed, politically aware and public-spirited citizens. See C.B. MACPHERSON, THE LIFE AND TIMES OF LIBERAL DEMOCRACY 47-48, 50-52 (1977). This theory has probably found its most influential modern expression in the writings of John Stuart Mill. See JOHN STUART MILL, Considerations on Representative Government, in ON LIBERTY AND OTHER ESSAYS 205, 303-24 (John Gray ed., Oxford University Press 1991).

A more recently developed democratic theory that has received extensive attention in the legal literature is deliberative democracy, a civic republican-inspired theory that stresses open, ethical dialogue as the defining feature of a good polity. See, e.g., CASS R. SUNSTEIN, THE PARTIAL CONSTITUTION (1993); David M. Estlund, Who's Afraid of Deliberative Democracy? On the Strategic/Deliberative Dichotomy in Recent Constitutional Jurisprudence, 71 TEX. L. REV. 1437 (1993); Miriam Galston, Taking Aristotle Seriously: Republican-Oriented Legal Theory and the Moral Foundation of Deliberative Democracy, 82 CAL. L. REV. 329 (1994).

Although a few voting rights theorists have occasionally made arguments that seem to invoke a conception of developmental or deliberative democracy, see, e.g., Kathryn Abrams, "Raising Politics Up": Minority Political Participation and Section 2 of the Voting Rights Act, 63 N.Y.U. L. REV. 449, 476-479 (1988) (discussing personal benefits of po- 
racy, voting is significant because it is the means by which members of society protect their liberties from invasion by government. In theories of communitarian democracy, voting is significant because it is the hallmark of full membership in the political community. ${ }^{4 \sqrt{5}}$

\section{A. Protective Democracy}

Protective democracy ${ }^{47}$ is the theory of democracy most closely associated with liberalism, and with liberal thinkers such as Locke, Montesquieu and Madison. Under theories of protective democracy, the vote is valuable because it is the means by which members of society control the actions of their government-specifically, those actions that might threaten the liberties of the citizens.

Protective democracy is rooted in the Lockean idea, transmitted to Americans by way of the Declaration of Independence, that indi-

litical participation); Lani Guinier, More Democracy, 1995 U. CHI. LEGAL F. 1, 1 (hinting at aspects of deliberative democracy), I can find no evidence that any litigant has ever supported a claim of infringement of the legal right to vote on such grounds. That is, no litigants appear to have come before the Court and argued, for example, that they cannot be denied the right to cast a ballot because doing so impairs their ability to develop their human capacities or deprives them of the opportunity to engage in dialogue. Nor has any court to my knowledge said anything even remotely suggesting acceptance, or even awareness, of these kinds of theories.

A very different view is taken by Frank Michelman, who has argued that the Supreme Court's voting rights cases express, or at least do not exclude, an underlying judicial conception of deliberative democracy. See Frank I. Michelman, Conceptions of Democracy in American Constitutional Argument: Voting Rights, 41 FLA. L. REV. 443 (1989). I find his readings of the cases distinctly unpersuasive. Some of the reasons for my skepticism can be found in James A. Gardner, Shut Up and Vote: A Critique of Deliberative Democracy and the Life of Talk, 63 TENN. L. REV. 421 (1996).

${ }^{16}$ The distinction between protective and communitarian democracy relied on here is certainly not original. Numerous others have noted this duality, though their terminology has often been different. See, e.g., QUIET REVOLUTION IN THE SOUTH: THE IMPACT OF THE VOTING RIGHTS ACT 1965-1990, at 15-16 [hereinafter QUIET REVOLUTION] (Chandler Davidson \& Bernard Grofman eds., 1994) (referring to the ability of voting rights both to obtain "policy benefits to the minority communities" and "to confer full citizenship on the members of the group"); Karlan, Undoing the Right Thing, supra note 29, at 5-6 (describing "formal" and "functional" aspects of the right to vote); Karlan, Maps and Misreadings, supra note 29, at 213-15 (describing the Voting Rights Act as aimed both at the political influence that comes with representation and the symbolic value of civic inclusion); Milton D. Morris, Black Electoral Participation and the Distribution of Public Benefits, in MINORITY VOTE DILUTION 271, 271 (Chandler Davidson ed., 1989) (describing black political participation as influencing the actions of government and having symbolic importance).

${ }^{17}$ Although the term is C.B. Macpherson's, see MACPHERSON, supra note 45, I follow more closely here the usage suggested by David Held. See HELD, supra note 44. 
viduals have certain inalienable rights, ${ }^{48}$ and that these rights can be better protected jointly, in a society living under the consensual rule of a government, than individually. ${ }^{49}$ The transfer of power to a government, even consensually, always entails some risk: governments are run by people, and people can abuse their powers. Choosing officeholders by election is thus a means of assuring that the government exercises its powers consistent with the popular will. ${ }^{50}$ As C.B. Macpherson put it, in a protective democracy, "the extent of the franchise is a measure of democratic government only in so far as the exercise of the franchise can make and unmake governments. ${ }^{\text {51 }}$

A voting rights claim under a theory of protective democracy, then, is a claim that one's ability to protect one's liberties from governmental intrusion is inadequate. Consequently, to seek the vote under such a theory is to seek the ability to protect one's liberty by controlling the identity of officeholders and, indirectly, their actions.

Much language in the Supreme Court's voting rights opinions is highly suggestive of an underlying theory of protective democracy. For example, the Court has maintained continuously for over a century that the right to vote is a fundamental right "because [it is] preservative of all rights. ${ }^{\text {"52 }}$ What the Court seems to mean by this phrase is that direct constitutional protection of substantive rights can go only so far toward protecting the rights and liberties of citizens because the constitutional protection of rights depends for its efficacy on observance of the Constitution by government officials. The right to vote differs from other substantive rights in that it permits the people directly to protect their substantive rights by replacing officials who refuse to observe those rights.

\section{B. Communitarian Democracy}

Communitarian theories of democracy are in some sense the most elemental of democratic theories: they respond primarily to the visceral human need for inclusion. One of the earliest and most ro-

13 DECLARATION OF INDEPENDENCE, para. 2 (U.S. 1776).

49 See, e.g., JOHN LOCKE, SECOND TREATISE OF GOVERNMENT (C.B. Macpherson ed., 1980) (1690), §§ 4, 87, 89, 95-99.

so See, e.g., HELD, supra note 44, at 61 ("[T] he governors must be held accountable to the governed through political mechanisms... which give citizens satisfactory means for choosing, authorizing and controlling political decisions.").

${ }^{31}$ MACPHERSON, supra note 45, at 23.

${ }^{32}$ Yick Wo v. Hopkins, 118 U.S. 356, 370 (1886); accord Reynolds v. Sims, 377 U.S. 533,562 (1964). 
mantic expressions of the communitarianism of American democracy can be found in the poetry of Walt Whitman. In Whitman's vision, exclusion from the electoral process is exclusion in the deepest possible sense from the essence of American society. American democracy, Whitman claims, is the pinnacle of American achievement, dwarfing even the most magnificent of natural wonders:

If $I$ should need to name, $O$ Western World, your powerfulest scene and show,

'Twould not be you, Niagara-nor you, ye limitless prairies-nor your huge rifts of canyons, Colorado,

Nor you, Yosemite-nor Yellowstone, with all its spasmic geyser loops ascending to the skies, appearing and disappearing,

Nor Oregon's white cones-nor Huron's belt of mighty lakes -nor Mississippi's stream:

- This seething hemisphere's humanity, as now, l'd namethe still small voice vibrating-America's choosing day,

(The heart of it not in the chosen-the act itself the main, the quadriennial choosing,) ...

The final ballot-shower from East to West-the paradox and conflict,

The countless snow-flakes falling-(a swordless conflict,

Yet more than all Rome's wars of old, or modern Napoleon's:) the peaceful choice of all...

These stormy gusts and winds waft precious ships,

Swell'd Washington's, Jefferson's, Lincoln's sails.

To be excluded from the vote is, according to this view, to be excluded from the most important and impressive activity in which Americans can engage. Yet it is more than that. Whitman ardently espoused an organic relationship between the concept of America, its physical characteristics, and the individuals who peopled it; America, for Whitman, was its people made immanent:

O I see flashing that this America is only you and me,

Its power, weapons, testimony, are you and me,

Its crimes, lies, thefts, defections, are you and me,

Its Congress is you and me, the officers, capitols, armies,

ships, are you and me,

Its endless gestations of new States are you and me.

is WALT WHITMAN, Election Day, November, 1884, in LEAVES OF GRASS 517 (Harold W. Blodgett \& Sculley Bradley eds., 1965).

${ }^{5}$ WALT WhITMAN, By Blue Ontario's Shore, in LEAVES OF GRASS, supra note 53, at 353. 
Yet this relationship also flows in the other direction; not only is America its people, but its people are America:

I match my spirit against yours you orbs, growths, mountains, brutes,

Copious as you are $I$ absorb you all in myself, and become the master myself,

America isolated yet embodying all, what is it finally except myself?

These States, what are they except myself? ${ }^{55}$

If America and its people commune immanently in one another, and if voting is the most significant and defining achievement of American society, then those who are denied the vote are denied much more than the opportunity to participate in the democratic process: they are denied the transcendental possibility of becoming a part of America-indeed, of becoming America itself. No form of social alienation could be more complete, and it is doubtless no coincidence that Whitman describes the fate of the disenfranchised American in terms that resemble those used to describe the fate of the Christian denied communion with God.

A far less romantic, but equally powerful, account of a communitarian theory of democracy appears in Judith Shklar's short book, Citizenship in America. ${ }^{56}$ For Shklar, the key to understanding American attitudes toward voting lies, paradoxically, in understanding the American experience with slavery. Voting, she argues, stands in such stark contrast to slavery that "[t]he ballot has always been a certificate of full membership in society," an indicator of "social standing" that has the "capacity to confer a minimum of social dignity" on those who have it. ${ }^{57}$

In Shklar's view, a demand for the vote indicates not "an aspiration to civic participation as a deeply involving activity," but rather "a demand for inclusion in the polity, an effort to break down excluding barriers to recognition. ${ }^{53}$ Historically, voting thus became "an affirmation of belonging, ${ }^{, 59}$ as well as a means of "distancing the citizen from his inferior, especially slaves and women." Voting, then, is

si Id. at 354.

3 JUDITH N. SHKLAR, CITIZENSHIP IN AMERICA: THE QUEST FOR INCLUSION (1991).

37 Id. at 2.

${ }^{38} I d$. at 3 .

33 Id. at 26 (citing KIM EZRA SCHIENBAUM, BEYOND THE ELECTORAL CONNECTION 10 (1984)).

co Id. at 27. 
something to be had rather than something to be done. To seek the vote is to seek formal recognition as a full member of society; to be denied the vote is to be either excluded altogether from membership in the community or consigned to some kind of second-class citizenship. ${ }^{61}$

\section{The COURT'S PREFERENCE FOR COMMUNITARIAN-BASED CLAIMS}

Over the years, plaintiffs have asserted many varieties of voting rights claims based, sometimes explicitly though more often implicitly, on underlying theories of protective or communitarian democracy. The protective democracy approach seems especially appealing because it relies on a political theory strongly embraced by the nation's founding generation, and because it uses a vocabulary that is deeply embedded in American constitutional law. ${ }^{62}$ These factors might lead us to expect the Court to be particularly receptive to claims based on notions of protective democracy.

Examination of the Court's language seems to bear out this expectation. The Court has characterized the right to vote as "preservative of other basic civil and political rights;" it has identified "fair and effective representation" as a primary goal of the Constitution's political structure; ${ }^{64}$ and it has condemned the "debasement" or "dilution" of the value of the vote through practices that diminish the

${ }^{61}$ This account of communitarian democracy corresponds well with what Karlan has called the "formal" aspect of voting. See Karlan, Undoing the Right Thing, supra note 29 , at 5 (asserting that the "formal" importance of voting is how it "announces that the voter is a full member of the political community"); see also KENNETH L. KARST, BELONGING TO AMERICA: EQUAL CITIZENSHIP AND THE CONSTITUTION 93 (1989) ("Voting is not just an instrument for achieving power . . . ; it is an assertion of belonging to a political community."); QUIET REVOLUTION, supra note 46, at 16 (stating that voting rights "confer full citizenship on the members of the [minority] group"); Pamela S. Karlan, Not by Money But by Virtue Won? Vote Trafficking and the Voting Rights System, 80 VA. L. REV. 1455, 1465 (1994) (describing the benefits of voting in "expressive" terms, especially for historically disadvantaged groups, as "a way of declaring one's full membership in the political community").

${ }^{62}$ The opinions of Chief Justice John Marshall are fairly canonical accounts of the protective democracy theory, particularly his opinion in McCulloch v. Maryland, 17 U.S. (4 Wheat.) 316 (1819) (account of the Constitution as formed by the people as well as an account of the enumerated powers and electoral checks). See also James A. Gardner, Consent, Legitimacy and Elections: Implementing Popular Sovereignty Under the Lockean Constitution, 52 U. PITT. L. REV. 189, 205-211 (1990) (setting out evidence of the Constitution's adoption of the Lockean theory of protective democracy).

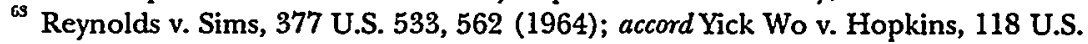
356,370 (1886).

${ }^{\mathrm{G}}$ Reynolds, 377 U.S. at 565. 
influence of its possessor. ${ }^{\text {fi }}$ This is, plainly, the vocabulary of protective democracy.

Yet, although it routinely speaks the language of protective democracy, the Court has proven surprisingly hostile to voting rights claims invoking that theory. In fact, plaintiffs who challenge an electoral structure on the ground that it leaves them with an inadequate ability to protect their rights and interests from majority tyranny are overwhelmingly likely to be shown the courthouse door. In sharp contrast, the plaintiffs most likely to meet with success as Supreme Court litigants are those who base their claims on communitarian theories-those who complain, that is, of being stigmatized by some demeaning form of exclusion from the community's political life.

This Part examines a number of Supreme Court decisions dealing with a wide range of voting rights issues, paying particular attention to the nature of the plaintiffs' claims, and their judicial reception. Section A deals with voting rights claims brought by plaintiffs who entirely lack the vote. ${ }^{6 x}$ Sections $\mathrm{B}$ and $\mathrm{C}$ deal with voting rights claims brought by plaintiffs who already have the franchise, but who claim that the right to vote involves something more. Section $B$ examines the one-person, one-vote cases, while Section $\mathrm{C}$ covers claims to a right to representation. Finally, Section $D$ relies on the patterns identified in the previous Sections to offer an explanation for the Court's sudden, newfound hostility toward section 2 of the Voting Rights Act. I argue that the problem with section 2 as amended in 1982, is its implementation of a protective democracy solution to a problem that the Court has deemed communitarian.

\section{A. Right to Vote Claims Without the Vote: The Right to the Franchise}

\section{Introduction: Holt}

Let us begin our examination of the Court's voting rights decisions by considering what ought to be an easy case. In Holt Civic Club v. City of Tuscaloosa, ${ }^{67}$ residents of Holt, Alabama, a suburb of Tuscaloosa, brought suit to invalidate an Alabama statute that subjected Holt to Tuscaloosa's "police and sanitary" regulations without providing Holt's residents with any voice in the selection of Tuscaloosa mu-

6. Id. at 555; see also Davis v. Bandemer, 478 U.S. 109, 118 (1986).

"Such claims are sometimes referred to as "first-generation" voting rights claims. See GUINIER, TYRANNY, supra note 29, at 49; QUIET REVOLUTION, supra note 46, at 14.

${ }^{67} 439$ U.S. 60 (1978). 
nicipal officials. ${ }^{\text {GS }}$ Like other Alabama cities, Tuscaloosa was authorized by state law to adopt a wide variety of ordinances governing many aspects of city life. The challenged law authorized Tuscaloosa to enforce some, though not all, city ordinances within a "police jurisdiction" extending three miles beyond the city's borders, an area which included the town of Holt. ${ }^{69}$ At the time of the suit, these ordinances, among other things, governed the granting of licenses for hotels, florists, and ambulances; established building permit and inspection requirements; regulated several aspects of public health; established motor vehicle inspection and operation requirements; and created over a dozen criminal offenses. ${ }^{70}$ However, the challenged statute did not provide for residents of the extended police jurisdiction to vote for any of the Tuscaloosa officials who made, administered and enforced these laws.

A group of Holt residents filed suit challenging the law on the ground that it unconstitutionally denied residents of the "police jurisdiction" the right to vote. ${ }^{71}$ The United States Supreme Court made short work of this contention: the Court ruled that Tuscaloosa could constitutionally deny the plaintiffs the right to vote in Tuscaloosa elections because the plaintiffs lived in Holt, not Tuscaloosa. ${ }^{72}$

Just what did the plaintiffs in Holt mean when they claimed that their exclusion from Tuscaloosa elections violated their right to vote? To begin with, it hardly seems likely that the plaintiffs intended to rely on a communitarian theory of democracy. Surely, they were not complaining about some kind of wrongful exclusion from the Tuscaloosa political community; as suburbanites, the plaintiffs had deliberately rejected membership in the Tuscaloosa community in favor of a separate, suburban political community. They did not seek annexation by Tuscaloosa, or any other form of inclusion; if anything, they wanted to be free of Tuscaloosa entirely.

Instead, the basis of the plaintiffs' invocation of the right to vote is an almost paradigmatic expression of a theory of protective democracy. The plaintiffs did not contend that the police jurisdiction of

is See id. at 61-62.

${ }^{6}$ See id. at 61 .

${ }^{70}$ See id. at 82-84 n.10 (Brennan, J., dissenting).

7 In the Court's words, the plaintiffs "claimed that the city's extraterritorial exercise of police powers over Holt residents, without a concomitant extension of the franchise on an equal footing with those residing within the corporate limits, denies residents of the police jurisdiction rights secured by the Due Process and Equal Protection Clauses." Id. at 62-63.

${ }^{72}$ See id. at 68-70. 
Tuscaloosa could not be extended beyond its boundaries, but that it could not be so extended without a concomitant extension of the franchise. The plaintiffs wanted to be able to vote in Tuscaloosa elections so that they would have "a voice in their government." In other words, they did not want to be subjected to laws enacted by representatives whom they had no hand in choosing and over whom they exercised no effective control.

The Holt residents' claim is instantly recognizable as one of the most venerable and powerful in the entire tradition of American history and politics: a claim of the inadequacy of virtual representation. The doctrine of virtual representation arose in the eighteenth century as a defense to the haphazardness of the British system of allocating representatives to Parliament, a system in which the great majority of British subjects were not entitled to vote. ${ }^{74}$ Those unable to vote directly for parliamentary representatives were said, nonetheless, to be represented "virtually" because their interests would necessarily be taken into account by a Parliament engaged in the deliberative process of identifying and pursuing the common good of the entire commonwealth. ${ }^{75}$

When this doctrine was invoked to justify the disenfranchisement of the American colonists, it "met at once with flat and universal rejection, ultimately with derision. ${ }^{76}$ Americans argued that no member of Parliament could possibly represent them adequately because of a significant divergence between the interests of the mother country and its colonies." In one well-known capsulization of the American view, Arthur Lee wrote: "'[although o] ur privileges are all virtual, our sufferings are real.... We might have flattered ourselves, that a virtual obedience, would have exactly corresponded with a virtual representation .... ${ }^{778}$ This view ultimately evolved into the belief that rep-

${ }^{73}$ Id. at 80 (quoting appellants' complaint).

77 See Bernard BaILYN, THE IDEOLOGICAL ORIGINS Of THE AMERICAN REVOLUTION 163 (1967).

${ }^{73}$ Id.; see also PITKIN, supra note 38, at 168-89 (discussing Edmund Burke's concept of representing unattached interests); J.R. POLE, POLIICAL REPRESENTATION IN ENGLAND AND THE ORIGINS OF THE AMERICAN REPUBLIC 443-44 (1966) (discussing the doctrine of interest representation); JOHN PHILLIP REID, THE CONCEPT OF REPRESENTATION IN THE AGE OF THE AMERICAN REVOLUTION 50-62 (1989) (discussing the theories of interest and virtual representation).

${ }^{76}$ BAILYN, supra note 74, at 167.

7 See id. at 167-68; REID, supra note 75, at 59-60; cf. PITKIN, supra note 38, at 173-75.

${ }^{78}$ BAILYN, supra note 74, at 168 (quoting Arthur Lee, Monitor III, VIRGINIA GA. ZETTE, Mar. 10, 1768). 
resentative government is legitimate only when those supposedly represented have had some direct say in the selection of the representatives. ${ }^{79}$

In light of this history, no claim, it seems, could be more certain of a generous constitutional reception than the claim that virtual representation provides inadequate protection for the rights and liberties of citizens denied the vote. Yet the Court, surprisingly, was deaf to the Holt plaintiffs' protective democracy claim. Rather than responding to the protective claim on its merits, the Court issued a distinctly communitarian response: you are not members of the community, the Court said, so you have no legitimate claim to participate in the affairs of the community-you have no right to vote there.

The Court articulated its position as follows. Holt residents, it held, had no right to participate in Tuscaloosa elections because they were not members of the relevant political community: "our cases have uniformly recognized that a government unit may legitimately restrict the right to participate in its political process to those who reside within its borders." ${ }^{80}$ It may well be, the Court continued, that the actions of Tuscaloosa affect Holt residents, but that "proves too much. The imaginary line defining a city's corporate limits cannot corral the influence of municipal actions. A city's decisions inescapably affect individuals living immediately outside its borders." ${ }^{281}$ The Court then listed a few such decisions, including the granting of building permits on the city's fringe, changes in the city's sales or ad valorem taxes, and the construction of waste facilities near municipal borders. $^{82}$

The Court's reasoning entirely missed the point of the plaintiffs' claim. The plaintiffs were not trying to minimize the fact that they lived in a different community-that was precisely their point. The problem, in their view, was that they were governed by a political community different from the one to which they belonged. As Justice Brennan wrote in dissent:

At the heart of our basic conception of a "political community" ... is the notion of a reciprocal relationship between the process of government and those who subject themselves to that process by choosing to live within the area of its authoritative application. Statutes such as those challenged in this case... fracture this relationship by severing

\footnotetext{
${ }^{75}$ See id. at 173-74.

${ }^{80}$ Holt, 439 U.S. at 68-69.

${ }^{81}$ Id. at 69.

${ }^{82}$ See id.
} 
the connection between the process of government and those who are governed in the places of their residency....

While the Court was correct that the actions of one jurisdiction inevitably have some kind of "spillover" effect on neighboring jurisdictions, there is a significant difference between living with neighbors and living under those neighbors-the difference between comity under independent self-government and outright political subjection. One would think that in a nation whose political origins lie in an intellectual rejection of virtual representation, this difference would resonate with judges interpreting the Constitution. The Court, however, did not even hear the protective democracy claim.

\section{Kramer and Gomillion}

The Court's ruling in Kramer v. Union Free School.District No. $15^{84}$ provides a stark contrast to the ruling in Holt. Kramer concerned the constitutionality of a New York law setting voting qualifications in local school board elections. School boards in New York are responsible for operating the schools, prescribing curricula, and financing the school budgets through property taxes. ${ }^{85}$ Under the challenged law, qualified voters in school board elections were limited to parents or guardians of children enrolled in the local public schools, and anyone who owned or leased taxable property within the district. ${ }^{86}$ The state's purpose in enacting the law was to limit the franchise to those with the most direct stake in school board decisions: those whose children actually attended local schools, and those who paid school taxes. ${ }^{87}$ The plaintiff, a childless adult who lived rent free in his parents' home, challenged his exclusion from the voting rolls. ${ }^{83}$ The Court struck down the law. ${ }^{89}$

Compared to the plaintiffs in Holt, the plaintiff in Kramer had a far less plausible claim that his inability to vote impaired in any sig-

Id. at 82 (Brennan, J., dissenting) (citations and footnote omitted).

395 U.S. 621 (1969).

${ }^{85}$ See id. at 623-24.

See id. at 622 (explaining $\$ 2012$ of the New York Education Law).

${ }^{87}$ See id. at 630-31. For a variety of accounts of the constitutionally pertinent interest, see Richard Briffault, Who Rules at Home?: One Person/One Vote and Local Governments, 60 U. CHI. L. REv. 339, 355-56 (1993); Michelman, supra note 45, at 463-64; Melvyn R. Durchslag, Salyer, Ball, and Holt: Reappraising the Right to Vote in Terms of Political "Interest" and Vote Dilution, 33 CASE W. RES. L. REV. 1, 42-43 (1982).

See Kramer, 395 U.S. at 624-25.

${ }^{89}$ See id. at 633. 
nificant way his ability to protect his rights and liberties from government infringement. The residents of Holt were subject to all manner of laws, including criminal and traffic offenses, made by Tuscaloosa officials. Holt residents who wanted to obtain a license, build a home, or drive on the streets had to obey laws enacted by officials for whom they did not vote. ${ }^{90}$ The statute in Kramer, in contrast, was designed in large part to avoid such a situation: school board decisions primarily affect schoolchildren and property taxes, and those whose children or pocketbooks were implicated had the vote, enabling them to protect their interests against potential government intrusions. As a result, any claim by Kramer based on a theory of protective democracy would have had to rely on a far more attenuated connection between the actions of the school board and the plaintiff's rights and interests than existed in Holt. In fact, Kramer did offer such an argument, contending that local tax rates affected "the price of goods and services in the community" $\rightarrow$ a remote relationship, at best. ${ }^{92}$

While it is perhaps not inconceivable that such a protective democracy claim might rise to constitutional significance, Kramer's voting-rights claim fits far more comfortably within a communitarian theory of democracy. What really bothered the plaintiff, it seems, was the fact of his exclusion, not the result of it. "All members of the community," he flatly asserted, "have an interest in the quality and structure of public education." ${ }^{, 93}$ Nor was there any evidence that the plaintiff or any other excluded individuals had ever actually been harmed by a decision of a school board. Under the circumstances, the interest claimed by the plaintiff seems to arise less in virtue of any impact on actual individuals like him than in virtue of community membership itself; the interest, in other words, is definitional-it defines who is and who is not a member of the community. ${ }^{94}$ In any

${ }^{90}$ For a sample of the Tuscaloosa laws to which Holt residents were subjected, see Holt Civic Club v. City of Tuscaloosa, 439 U.S. 60, 82 n.10 (1978) (Brennan, J., dissenting).

91 Kramer, 395 U.S. at 630.

${ }^{92}$ The Court recently rejected a strikingly similar chain of effects as insufficient to sustain the exercise of the congressional power to regulate interstate commerce. See United States v. Lopez, 115 S. Ct. 1624, 1659-62 (1995) (Breyer, J., dissenting).

${ }^{93}$ Kramer, 395 U.S. at 630.

${ }^{94}$ Cf. Sanford Levinson, Suffrage and Community: Who Should Vote?, 41 FLA. L. REV. 545, 555-57 (1989) (criticizing formal definitions of citizenship); Briffault, supra note 87 , at $345,350,355-56$ (arguing that the Court simply assumes sufficiency of the interest). 
event, the Court proved highly receptive to the plaintiff's claim. At one point in the opinion, the Court listed several other classes of people disenfranchised by the New York law, including "senior citizens ...; clergy, military personnel, and others who live on taxexempt property; boarders and lodgers," parents of preschoolers, and parents of children who attend private school. ${ }^{95}$ This litany seems calculated to emphasize the exclusionary character of the law; the Court does not seem to be saying "here is a list of people whose liberty may be imperiled," but rather "here is a list of valued community members who are barred from participating in this important event."

The contrast with Holt is instructive. Both Kramer and the Holt residents were represented only virtually on the pertinent municipal councils because they could not vote. Moreover, the school board had much less power to harm Kramer than Tuscaloosa had to harm the citizens of Holt. The Holt residents, however, by living in the suburbs, had voluntarily excluded themselves from the municipal political community and thus were confined to basing their voting-rights claim on the need to protect their interests from infringement by a government in which they were unrepresented. Kramer, in contrast, lived by choice within the pertinent political community ${ }^{956}$ but was excluded involuntarily from its electoral processes. This gave his claim a communitarian character that apparently contributed to the different result.

Gomillion v. Lightfoot ${ }^{97}$ has much in common with Kramer. Gomillion involved a challenge by black voters to a law that redrew the boundaries of Tuskegee, Alabama. ${ }^{98}$ Before the challenged law was enacted, the city of Tuskegee formed a square within which black residents outnumbered white residents by about four to one." The challenged law contracted the city boundaries into an odd, twentyeight-sided figure that excluded from the redrawn city limits all but a

${ }^{95}$ Kramer, 395 U.S. at 630.

${ }^{96}$ There is of course a definitional problem lurking here: what exactly is the pertinent political community? Kramer claimed that it was the community defined by the geographical reach of school board authority, while New York claimed that it was the nongeographical community of parents and taxpayers. The Court, without explanation, chose Kramer's definition. For commentary on this aspect of the case, see sources cited supra note 94 .

364 U.S. 339 (1960).

${ }^{93}$ See id. at 340.

99 See BerNard TAPER, GOMILLION versus LightFOOT: THE TUSKEGEE GERRYMANDER CASE 11 (1962). 
handful of black families. ${ }^{100}$ Virtually all of the former Tuskegee's black residents suddenly found themselves living in an unincorporated part of Macon County. ${ }^{101}$ Although these individuals could still vote, as they had before, for federal, state and county officials, they could no longer vote for Tuskegee officials because they no longer lived in the city. ${ }^{102}$ The Court invalidated the redistricting. ${ }^{103}$

What kind of voting-rights claim did the Gomillion plaintiffs advance? As in Kramer, it seems implausible that the plaintiffs relied on a theory of protective democracy. Under such a theory, people need the vote to enable them to control government officials who have the power to invade their liberties. ${ }^{104}$ Yet the blacks districted out of Tuskegee had just this power: like other residents of unincorporated parts of Macon County, they could vote for every official at every level, whether federal, state or county, who had legal authority over them. Although they could no longer vote for Tuskegee officials, neither were they governed by Tuskegee, unlike the plaintiffs in Holt. The Gomillion plaintiffs thus enjoyed, as much as anyone else in Alabama, the ability to use the ballot to protect their interests. ${ }^{105}$

Clearly, the offense of which the Gomillion plaintiffs complained was one against their sense of community. The plaintiffs had lived within the Tuskegee political community and had measured their status within that community in part by their ability, at least in the-

\footnotetext{
${ }^{100}$ See Gomillion, 364 U.S. at 341.

${ }^{101}$ See TAPER, supra note 99 , at 85.

${ }^{102}$ See id.

${ }^{103}$ See Gomillion, 364 U.S. at 348.

10s See discussion supra, Part I.A.
}

${ }^{105}$ At least, this appears to be the case according to the Court's sketchy account of the facts. Other facts not relied on by the Court paint a somewhat different picture. Blacks also outnumbered whites in Macon County by about four to one, but because of racial discrimination by county officials in voter registration, may have faced significant obstacles to protecting their interests in county elections. Many blacks in Tuskegee were associated with the Tuskegee Institute and were not only qualified voters but had advanced degrees and were far more literate than most of the town's white citizens. Alabama officials might have thought that it would be difficult ultimately to deny registration to such voters, in which case dispersing them in Macon County might have weakened their voting influence far more than if they had been concentrated in the small town of Tuskegee. See TAPER, supra note 99, at 11, 13-14, 34-35; see also United States v. Alabama, 192 F. Supp. 677 (M.D. Ala. 1961) (awarding the United States injunctive relief against state and county registrars under the Civil Rights Act of 1957 for defendants' deliberate discriminatory denial of registration). Nothing in the Court's opinion however, suggests that it relied on or even knew of these additional facts. 
ory, ${ }^{106}$ to vote there. Like Kramer, Tuskegee's black citizens had been excluded from full membership in the community by being disenfranchised; unlike the residents of Holt, this exclusion was involuntary, and thus all the worse in the Court's view.

\section{Other Cases}

Many other disenfranchisement cases reveal the same trend: voting-rights claims based on protective democracy fare poorly, while those based on communitarian considerations fare better. For example, the United States Supreme Court has three times considered and rejected claims that the right to vote requires that certain appointive offices be filled by election. In Fortson v. Morris, ${ }^{107}$ the Court sustained a section of the Georgia Constitution providing for selection of the Governor by the state legislature if no candidate obtained a majority in a popular gubernatorial election. In Valenti $v$. Rockefeller ${ }^{108}$ and Rodriguez v. Popular Democratic Party, ${ }^{109}$ the Court sustained state practices of filling legislative vacancies by, respectively, gubernatorial and party appointment, rather than by popular election.

A claim that a particular office should be filled by election rather than by appointment is unlikely to rest on a communitarian theory of democracy. Since no one votes for that office, no individual's status within the community is implicated by the structural decision to appoint rather than elect. On the other hand, there is a clear protective democracy rationale behind the claim that offices must be filled by election: those who make such claims seem to be saying that their rights and liberties cannot be adequately secured through indirect control over the appointing official or body; the requisite degree of protection can be obtained only through direct election of the official in question. ${ }^{110}$ The Court has rejected such claims in all three cases in

${ }^{106}$ In fact, Tuskegee officials discriminated against the town's black citizens in voter registration, so it is unclear that they would have been able successfully to register at the time of the suit. See TAPER, supra note 99, at 34-36. If Gomillion and his coplaintiffs relied on a communitarian theory of democracy, then they were relying on a vision of their community that was far from fully realized.

${ }^{107} 385$ U.S. 231 (1966).

${ }^{103} 393$ U.S. 405 (1969).

${ }^{109} 457$ U.S. 1 (1982).

${ }^{10}$ See Sheldon H. Nahmod, Reflections on Appointive Local Government Bodies and a Right to an Election, 11 DUQ. L. REV. 119 (1972). A similar assumption seems to be at work in the state constitutional reform movement of the Progressive era, in which many formerly appointive offices were made elective to improve popular control over 
which they have been advanced.

The Court rejected another protective democracy claim in Salyer Land Co. v. Tulare Lake Basin Water Storage District. ${ }^{\text {II }}$ There, the plaintiffs challenged the electoral structure of a limited-purpose government district with responsibility for water storage and flood control in a rural, agricultural area of California. Eligibility to vote for the District's board of directors was limited to landowners within its jurisdiction, and votes were allocated in proportion to land holdings. The plaintiffs proceeded on a rather straightforward protective democracy claim: they argued that their disenfranchisement left them without a voice on, and thus entirely at the mercy of, the Water District. Moreover, in contrast to Kramer ${ }^{12}$ or Holt, ${ }^{113}$ the plaintiffs in Salyer had already suffered significant harm at the District's hands: as a result of the District's water control decisions, a plaintiff's home had been submerged under 15.5 feet of water. ${ }^{114}$

Although it is difficult to imagine a more appealing protective democracy claim, including as it does a vivid example of the complete failure of virtual representation, the Court was unimpressed. As in Holt, the Court answered a protective democracy claim with a communitarian response. The relevant community, the Court said, consists of landowners, and you are not landowners; therefore you have no claim to the franchise. ${ }^{115}$ Evidently, the plaintiffs' efforts would have been better directed toward showing why their exclusion from the political community of landowners was inappropriate or demeaning. ${ }^{\text {"16 }}$

The residency requirement cases illustrate a point that the Salyer plaintiffs would have done well to heed: voting rights claims that can be supported by either a protective or communitarian theory seem to be most successful when couched in a way that appeals to communi-

state government. See C.H. HOEBEKE, THE ROAD TO MASS DEMOCRACY: ORIGINAL INTENT AND THE SEVENTEENTH AMENDMENT ch.3 (1995) (discussing the history of state governments and democratic reform).

"II 410 U.S. 719 (1973).

112395 U.S. 621 (1969).

"113 439 U.S. 60 (1978).

114 Salyer, 410 U.S. at 737-38 (Douglas, J., dissenting).

113 See id. at 728-33.

${ }^{116}$ This might have been a difficult argument to make. As Richard Briffault observed, the area's sparse population and lack of amenities showed "not an absence of governmental power for the district's governing board but the lack of a community within the district appropriate for self-government." Briffault, supra note 87, at 363-64. 
tarian values. In Carrington v. Rash, ${ }^{117}$ for example, the Court examined a Texas constitutional provision that prohibited extension of the franchise in state and local elections to members of the United States armed forces. A voting rights challenge to such an exclusion could rest on either protective or communitarian grounds. From a protective perspective, members of the armed forces could argue that they were subject to many state and local laws when serving in the armed forces and needed the ability to protect themselves through the franchise from the possibility of unjust and harmful legislation. From a communitarian perspective, the plaintiffs could argue that they were members of the state and local communities notwithstanding their military service and were entitled to full-fledged community membership, including the right to vote.

In striking down the Texas provision, the Court rested decisively on communitarian considerations. There is no hint that the Court was at all concerned with the plaintiffs' inability to influence the content of state and local laws that might affect them. ${ }^{118}$ Instead, what the Court found objectionable was the state's disenfranchisement of people who were "bona fide residents"-members of the political community-of Texas localities. ${ }^{119}$ Apparently, the Court was particularly offended by the notion that the military uniform, an affirmation of communal membership if ever there was one, should be converted into "the badge of disenfranchisement for the man or woman who wears it." 120

\section{B. Voting Rights Claims with the Vote: The One-Person, One-Vote Cases}

At this point, I want to deal with a possibly significant counterexample to the trend identified thus far: the one-person, one-vote cases. In this extensive and highly influential line of cases, ${ }^{121}$ the

117380 U.S. 89 (1965).

${ }^{118}$ In contrast, this was of considerable concern to Texas. One of its justifications for the disenfranchisement was the fear that the residents of a military base would possess an electoral influence that could "overwhelm a small local civilian community." Id. at 93.

119 Id. at 94.

${ }^{120}$ Id. at 97 (quoting Governor Ellis Arnall, Message to the General Assembly of Georgia 5 (Jan. 3, 1944)).

${ }^{121}$ The one-person, one-vote cases begin with Wesberry v. Sanders, 376 U.S. 1 (1964) and Reynolds v. Sims, 377 U.S. 533 (1964), which establish the basic principle, and move on to an extensive body of more refined cases elaborating precisely the extent to which election districts can vary from the ideal. See, e.g., Gaffney v. Cummings, 412 U.S. 735 (1973) (holding that minor deviations from mathematical equality in state 
Court established the principle that every person's vote must be counted equally. Although these cases seem at first glance to involve protective democracy claims, I hope to show in this Section that the one-person, one-vote cases are better understood as communitarian voting rights claims-or at least that is how the Court chose to understand them.

The leading one-person, one-vote cases are Wesberry $v$. Sanders ${ }^{122}$ and Reynolds $v$. Sims; ${ }^{123}$ the former establishes the one-person, one-vote principle in federal elections, the latter in state elections. Wesberry was an equal protection challenge brought by residents of Georgia's Fifth Congressional District. The average population in 1960 of Georgia's ten congressional election districts was about 400,000 . The Fifth District, however, had a population of over 820,000 . The smallest district, the Ninth, had a population of about 272,000 , less than onethird that of the Fifth. ${ }^{124}$ As the Court observed, "this inequality of population means that the Fifth District's Congressman has to represent from two to three times as many people as do Congressmen from some of the other Georgia districts. ${ }^{125}$ Conversely, a vote in the Fifth District went only a third as far toward electing a representative as a vote in the First. This meant, according to the plaintiffs, that their votes were not "given the same weight as the votes of other Georgians." ${ }^{216}$ The Court embraced this claim and invalidated the districting.

A similar arrangement was challenged in Reynolds. Under Alabama's scheme of state legislative election districts, which had not been adjusted since 1901,

only $25.1 \%$ of the State's total population resided in districts represented by a majority of the members of the Senate, and only $25.7 \%$ lived in counties which could elect a majority of the members of the House of Representatives. ... Bullock County, with a population of only 13,462 , and Henry County, with a population of only 15,286 , each were allo-

legislative districting fail to make out a prima facie case of malapportionment); Mahan v. Howell, 410 U.S. 315 (1973) (establishing a more lenient standard in state legislative districting); Kirkpatrick v. Presler, 394 U.S. 526 (1969) (requiring a good faith effort to achieve absolute equality in congressional districting). The Court extended the oneperson, one-vote principle to local governments in Avery v. Midland County, 390 U.S. 474 (1968).
122376 U.S. 1 (1964).
${ }^{123} 377$ U.S. 533 (1964).
124 Wesberry, 376 U.S. at 2.
${ }^{125}$ Id.
${ }^{126}$ Id. at 3. 
cated two seats in the Alabama House, whereas Mobile County, with a population of 314,301 , was given only three seats, and... Jefferson County, with over 600,000 people, was given only one senator, as was Lowndes County, with a 1960 population of only 15,417 , and Wilcox County, with only 18,739 people.

As in Wesberry, the plaintiffs, residents of some of the more populous districts, claimed that their right to vote was "denied by a debasement or dilution of the weight of a citizen's vote, ${ }^{128}$ and the Court agreed.

What kind of democratic theory underlies these kinds of voting rights claims? In a sense, the very notion of vote "dilution" suggests a theory of protective democracy. As we have seen, voting under a regime of protective democracy is a means by which citizens influence the actions of government for the purpose of protecting their rights and liberties. Those whose votes are weighted less than fully in the calculation of election results have a proportionately diminished ability to influence electoral outcomes. As a result, such individuals have a correspondingly diminished ability to influence governmental policies and to protect their liberties from hostile government actions.

Some of the language in Wesberry and Reynolds clearly reflects this view. In Wesberry, for example, the Court characterized Georgia's malapportionment as giving "some voters a greater voice in choosing a Congressman than others, ${ }^{129}$ and went on to analogize malapportionment in congressional districting to the "rotten boroughs" of Great Britain that the Framers so strongly condemned. ${ }^{130}$ In Reynolds, the Court went even further, analogizing vote dilution to outright disenfranchisement: "the right of suffrage can be denied by a debasement or dilution of the weight of a citizen's vote just as effectively as by wholly prohibiting the free exercise of the franchise." ${ }^{131}$ Because the right to vote is preservative of other rights, ${ }^{132}$ vote dilution claims must be scrutinized with equal care. From these propositions, the Court concluded both that legislatures "should be bodies which are collectively responsive to the popular will," ${ }^{\prime 33}$ and that equal numbers

${ }^{127}$ Reynolds, 377 U.S. at 545-46 (footnotes omitted).

${ }^{128}$ Id. at 555.

${ }^{129}$ Wesberry, 376 U.S. at 14.

${ }^{130}$ Id. The phrase "rotten boroughs" refers to the most egregious instances of malapportionment in eighteenth-century Britain. See supra text accompanying notes 7477.

${ }^{191}$ Reynolds, 377 U.S. at 555.

132 See id. at 562.

${ }^{13 s}$ Id. at 565. 
of voters should have equal control over the composition of the legislature. ${ }^{134}$

Yet even though this kind of vote dilution claim fits comfortablyperhaps most comfortably-within a theory of protective democracy, such claims can also be understood to rest on communitarian premises. ${ }^{135}$ Under a communitarian theory of democracy, the problem with severe malapportionment is not that it impairs the ability of some citizens to achieve a politically necessary degree of influence over government officials, but simply that it allocates unequally such influence, however slight, as citizens happen to have. The significance of malapportionment thus lies in the fact that possession of a "full" vote is understood to be a feature of full citizenship in society. Those who, because of improper districting, are given only a half or a third of a vote are not, in this view, given their full due as citizensthey are relegated to a kind of second-class citizenship.

Some critical passages in the Court's decisions suggest strongly that the Court ultimately viewed these cases in such a manner. For example, in stunningly direct language, the Court in Reynolds said: "To the extent that a citizen's right to vote is debased, he is that much less a citizen." ${ }^{136}$ The Court then proceeded immediately to link the debasement of voting strength to a kind of discrimination practiced against people on the basis of where they live:

134 Id.

195 One difficulty in conceptualizing malapportionment claims as invoking a theory of protective democracy is the minute difference in influence caused by malapportionment. After the 1980 reapportionment, for example, the average congressional district contained over 250,000 voters. See BRUCE E. CAIN, THE REAPPORTIONMENT PUZZLE 57 (1984) (explaining, after the 1980 census, that the average congressional district in California contained over 525,000 people and over 252,000 voters). As a result, the average vote had an infinitesimally small impact on electoral outcomessomething on the order of .000004 . As Bruce Cain has observed, "anything short of a massive population deviation would not substantially alter that value." Id. Thus, even the kind of wide population variations at issue in Wesberry could not have changed the fact that all voters in Georgia, whether residing in urban or rural areas, had votes whose protective impact was not significantly different from zero.

On the other hand, this same reasoning impugns any voting rights claim based on a theory of protective democracy, not just malapportionment claims, and gives rise to the so-called paradox of voting. For an overview, see Richard L. Hasen, Voting Without Law?, 144 U. PA. L. REV. 2135, 2136-37 (1996) (explaining the paradox that people vote even though the chance that they could affect the outcome is small). This paradox is the basis of economic theories of rational nonvoting. The classic study on this subject is ANTHONY DOWNS, AN ECONOMIC THEORY OF DEMOCRACY (1957). Discussion of this phenomenon is beyond the scope of this paper.

${ }_{136}$ Reynolds, 377 U.S. at 567. 
The fact that an individual lives here or there is not a legitimate reason for over-weighting or diluting the efficacy of his vote.... A nation once primarily rural in character becomes predominantly urban.... But the basic principle of representative government remains, and must remain, unchanged-the weight of a citizen's vote cannot be made to depend on where he lives.

Although the Court never explicitly identified the precise nature of the discrimination worked by Alabama's malapportionment, it made enough oblique references to communicate plainly that the discrimination disfavored there was by rural residents against urban dwellers. ${ }^{\text {I3s }}$ "Legislators," the Court wrote, "represent people, not trees or acres. Legislators are elected by voters, not farms or cities or economic interests." ${ }^{139}$ Furthermore, "[a] citizen, a qualified voter, is no more nor no less so because he lives in the city or on the farm."140

The Court's focus on the offense to voters' status as citizens and its characterization of Alabama's malapportionment as a kind of discrimination by the farm against the city suggest strongly that Wesberry and Reynolds are best understood as a kind of Gomillion for urbanites. That is, the one-person, one-vote cases should not be understood as the source of a body of law in which the Court acknowledges the legitimacy of voting rights claims based on theories of protective democracy. Rather, these cases reflect a judicial animosity toward the creation of a group of second-class citizens, whether defined by race or residence-the same kind of communitarian bias that runs throughout the Court's voting rights jurisprudence.

In the end, what happened in the one-person, one-vote cases is not unlike what happened in Holt. As in Holt, the Court was confronted with a voting rights claim couched predominantly in the language of protective democracy, yet chose ultimately to treat the claim as essentially communitarian. Unlike the plaintiffs in Holt however, the plaintiffs in the one-person, one-vote cases had not voluntarily removed themselves from the political community at whose hands they claimed mistreatment. Consequently, the Court had no trouble characterizing the plaintiffs as second-class citizens within their own political society-exactly the kind of plaintiffs who are entitled under

${ }^{197}$ Id.

${ }^{139}$ The Court never mentioned race as a factor in either Wesberry or Reynolds, yet race may indeed have been a factor if the Court was at least partly offended by discrimination against city dwellers on the assumption that they are disproportionately black.

159 Reynolds, 377 U.S. at 562.

${ }^{140}$ Id. at 568. 
communitarian-based theories of democracy to invoke the constitutional right to vote.

\section{Voting Rights Claims with the Vote: The Right to Representation}

The Court's preference for communitarian theories of democracy is also reflected in some of the more complex contemporary voting rights cases in which plaintiffs claim that the right to vote includes what I will call a "right to representation." Unlike the earliest generation of voting rights claims, these claims are generally made by people who already have what might be thought of as full rights of political participation. They may register to vote, cast ballots, and have their ballots counted and weighed equally; they may also participate in political campaigns and even run for office. Although these claims go by many different names-"vote dilution," lack of an "effective"142 or "meaningful" vote, and the inability to "elect legislators of their choice," for example-the underlying contention is almost always the same: the voter claims that having the vote is not enough, and that the right to vote includes an entitlement to some kind of reorganization of the political process that will enhance the voter's ability to influence political outcomes. Under the existing system, such plaintiffs say, their votes are "cancelled out,"145 "debased"146 or rendered "meaningless"; ${ }^{147}$ consequently, their right to vote entitles them to do more than simply cast ballots. Thus, the essence of the right-to-

${ }^{141}$ Davis v. Bandemer, 478 U.S. 109, 113 (1986) (reversing a district court's finding that Indiana's state apportionment did not unconstitutionally dilute votes); Mobile v. Bolden, 446 U.S. 55, 58 (1980) (plurality opinion) ("The complaint alleged that the practice of electing the City Commissioners at large unfairly diluted the voting strength of Negroes in violation of $\S 2$ of the Voting Rights Act of 1965, of the Fourteenth Amendment, and of the Fifteenth Amendment.").

${ }^{142} 42$ U.S.C. $\$ 1973 l$ (c) (1) (1994) (defining "vote" and authorizing activity to make a vote effective).

${ }^{143}$ Mobile, 446 U.S. at 104 (Marshall, J., dissenting) (criticizing a plurality of the Court for holding that "in the absence of proof of intentional discrimination by the State, the right to vote provides the politically powerless with nothing more than the right to cast meaningless ballots").

${ }^{144}$ White v. Regester, 412 U.S. 755, 766 (1973) (striking down a Texas legislative reapportionment scheme).

${ }^{45}$ Whitcomb v. Chavis, 403 U.S. 124, 129 (1971) (holding that the record before the Court was insufficient to show that minority votes were "cancel[led] out"); Fortson v. Dorsey, 379 U.S. 433, 439 (1965).

${ }^{116}$ Kirkpatrick v. Preisler, 394 U.S. 526, 531 (1969) (striking down Missouri's congressional reapportionment scheme because it debased votes by not having interdistrict population equality).

${ }^{117}$ Mobile, 446 U.S. at 104 (Marshall, J., dissenting). 
representation claim is that some individual or group is entitled to a restructuring of the electoral process that will guarantee, or at least greatly increase the likelihood, that the candidate preferred by the individual or group will be elected.

Almost all right-to-representation claims fall into one of two categories. The first kind of claim challenges the methods of election used within specific election districts, such as the use of multimember districts or at-large voting. The second kind of claim, which essentially alleges gerrymandering, challenges the lines that geographically separate one election district from another.

\section{Challenges to Multimember Districts}

What kinds of democratic theories underlie such claims? Let us begin by examining the two most common challenges to multimember districts. The first challenge alleges that voters in multimember districts have an inherent advantage over voters in single-member districts. The second challenge asserts that multimember districts wrongfully submerge the electoral influence of political minorities within the district.

\section{a. The Inherent Advantage Claim}

Perhaps the most straightforward and sweeping challenge to multimember districts appears in Whitcomb v. Chavis, ${ }^{148}$ one of the earliest right-to-representation cases. In Whitcomb, a group of black voters challenged the constitutionality of a multimember districting scheme in Marion County, Indiana, which allocated fifteen state representatives and eight state senators to the county. ${ }^{149}$ One basis for the plaintiffs' challenge was their contention that multimember districts are inherently unconstitutional because they provide disproportionate political influence to residents of the multimember district as compared with residents of single-member districts. ${ }^{150}$ The plaintiffs relied on a mathematical theory of voter influence according to which "the true test of voting power is the ability to cast a tie-breaking, or "critical' vote." Using this definition, the plaintiffs were able to demonstrate mathematically that the use of multimember districts

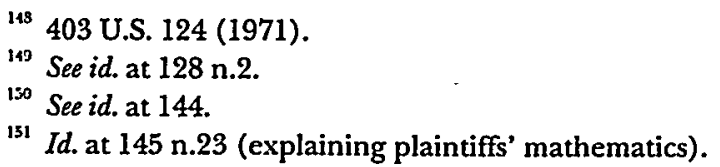


"gives undue voting power to the voter in the multi-member district since he has more chances to determine election outcomes than the voter in the single-member district." ${ }^{152}$ The plaintiffs also relied on another theory identifying a tendency among representatives of multimember districts to vote as a bloc. ${ }^{153}$ They claimed that voters in multimember districts have "more effective representation.... [S] ince multi-member delegations are elected at large and represent the voters of the entire district, they tend to vote as a bloc, which is tantamount to the district having one representative with several votes." ${ }^{\text {154 }}$

It is clear that the plaintiffs in Whitcomb were speaking the language of protective democracy. What concerned them was not any kind of exclusion, but the relative abilities of citizens to influence election results and, consequently, to influence their representatives. The Court recognized the nature of the underlying claim, characterizing it as a claim concerning "the quality of representation afforded by the multi-member district as compared with single-member districts."

As it has done with all the other protective democracy-based arguments examined thus far, the Court rejected the claim. ${ }^{156}$ The Court dismissed the plaintiffs' mathematical argument as "theoretical," ${ }^{157}$ and criticized it for failing to take into account "any" political or other factors which might affect the actual voting power of

${ }^{152}$ Id. at $144-45$.

133 See id. at $146-47$.

${ }^{134}$ Id. at 146.

${ }^{155}$ Id. at 142.

${ }^{156}$ In Whitcomb, the Court used strangely hedging language that gave the impression of not entirely closing the door to protective democracy-based challenges to multimember districts. The Court did not say, for example, that multi-member districting could not work a constitutionally cognizable form of discrimination, but only that nobody had "so far" demonstrated such discrimination. Id. at 143. The Court did not reject the plaintiffs' claims outright, but was "not ready" to endorse them. Id. at 147. It was not that the challenged practices were consistent with equal protection, but that the Court did "not yet deem [] it a denial of equal protection." Id. at 153. The Court did not say that the plaintiffs had failed to state a claim, but only that "experience and insight have not yet demonstrated that multi-member districts are inherently invidious." Id. at 159-60. Thus, the Court did not reject the claim absolutely, but only "[a]s presently advised." Id. at 160.

This language has tantalized voting rights advocates for years. But if the Court was ever on the cusp of recognizing such claims, it soon changed course dramatically. See, e.g., Mobile v. Bolden, 446 U.S. 55, 62 (1980) (requiring a showing of intentional discrimination).

${ }^{137}$ See Whitcomb, 403 U.S. at 147. 
the residents." 158 Likewise, the bloc voting argument "remains to be demonstrated in practice" and was deemed by the Court to be too theoretical and not adequately supported in the record. ${ }^{159}$

\section{b. Submersion Claims}

A more common challenge to multimember districts or other systems using at-large voting is a submersion claim-the contention that multimember districts "submerge minorities"160 by causing them to be underrepresented relative to their numbers within the district. The plaintiffs in Whitcomb, for example, also made a submersion claim: they argued that poor blacks in certain neighborhoods were unable to elect representatives of their choice to the state legislature under the multimember district system, but would be able to elect three representatives and one senator if the county were subdivided into single-member districts. ${ }^{161}$

Similarly, in White v. Regester, ${ }^{162}$ black and Mexican-American plaintiffs challenged the use of multimember districts in Dallas and San Antonio, Texas. Following the 1970 census, the Texas legislature enacted a reapportionment plan which divided the state's 150 House members into ninety election districts. Seventy-nine of the districts were singlemember districts in which residents of the district elected a single representative. Eleven of these districts, including the two challenged in the case, were multimember districts, meaning that residents of the district elected several representatives. ${ }^{163}$ Elections from the multimember districts were governed by a "place" rule. Under this rule, candidates were required to run for a particular place on the ticket and could not compete against candidates running for different places within the multimember district; as the Court observed, this turned the election of candidates from multimember districts into "a head-to-head contest for each position." 164 In their voting rights claim, the plaintiffs contended that they had been discriminatorily deprived of their right "to partici-

${ }^{133}$ Id. at 146 (citing Transcript at 39).

133 Id. at 147.

${ }^{160}$ Id. at 159.

${ }^{161}$ See id. at 129.

${ }_{162}^{162} 412$ U.S. 755 (1973).

16s See id. at 761.

19 Id. at 766. The Court also found that the discriminatory effects of the "place" rule were exacerbated by the requirement of a "majority vote as a prerequisite to nomination" in party nominating primaries. Id. 
pate in the political processes and to elect legislators of their choice."165

Simply as a matter of logic, the claims in these and similar cases appear to be based on a theory of protective democracy. Under communitarian theories of democracy, voting rights claims are claims to full membership in society. Because full membership in American society is defined in part by possession of the right to cast a ballot, those who lack such a right experience their disenfranchisement as a form of exclusion tantamount to a kind of second-class citizenship. Thus, communitarian theories in many cases seem to underlie challenges to disenfranchisement. Where individuals already have the franchise, however, communitarian claims seem somewhat less apt. If full membership in society is measured by having the right to cast a ballot, then those who have the vote have all to which communitarian theories entitle them. ${ }^{160}$

Consequently, the voting rights claims made in cases like Whitcomb and Regester are probably better thought of as protective in nature. The claimants in these cases complain about multimember districting not so much because it excludes them from full social membership as because the practice impairs their ability to use the vote to protect their rights and liberties. ${ }^{167}$ If we can never vote for a winner, the claimants seem to say, how can we ever use the ballot to protect ourselves from governmental overreaching? The plaintiffs' language in these cases bears out this reasoning. In Whitcomb, for example, the plaintiffs claimed that the districting scheme "diluted the force and effect" of the votes of poor blacks within the district. ${ }^{16 s}$ Under the Indiana scheme, they argued, the plaintiffs "have almost no political force or control over legislators." ${ }^{\text {"16y }}$ Indeed, the Court directly characterized the plaintiffs' claim as one complaining of "inadequate protection to minorities."

165 Id. IV.A.

tow The implications of relaxing this assumption are explored further infra Part

${ }^{367}$ For similar interpretations of vote dilution claims, see Joan F. Hartman, Racial Vote Dilution and Separation of Powers: An Exploration of the Conflict Between the Judicial "Intent" and the Legislative "Results" Standards, 50 GEO. WASH. L. REV. 689, 691, 709 (1982); Karlan, Maps and Misreadings, supra note 29, at 176 (giving an account of "qualitative" vote dilution).

${ }^{168}$ Whitcomb, 403 U.S. at 128.

IE Id. at 129 .

${ }^{170}$ Id. at 159. 


\section{c. The Court's Turn to Intentionality}

If submersion claims seem, both in logic and in rhetoric, to be based on a theory of protective democracy, then we would expect to see the Court reject such claims. This was indeed the outcome in Whitcomb, yet not in Regester. Why? The answer lies in a pattern that is becoming increasingly familiar: although the plaintiffs couched their claim in the language and logic of protective democracy, the Court answered in communitarian terms. It did so by turning strikingly to intentional discrimination as the benchmark against which such claims are evaluated.

In Whitcomb, for example, the Court had barely identified the submersion claim before it noted that "there is no suggestion here that Marion County's multi-member district, or similar districts throughout the State, were conceived or operated as purposeful devices to further racial or economic discrimination."171 Similarly, in Regester-the only case in which the Court has invalidated a multimember district on a submersion claim - the Court focused heavily on the local history of intentional racial and ethnic discrimination "in the fields of education, employment, economics, health, [and] politics." 72 Apparently, this record allowed the Court to infer, in the absence of direct evidence, that the multimember districts at issue were maintained deliberately, for the discriminatory purpose of minimizing black and Mexican-American political influence. ${ }^{173}$ This series of cases culminated in Mobile v. Bolden, ${ }^{174}$ in which the Court held that intentional discrimination was a necessary element of a vote dilution claim under either the Fourteenth or Fifteenth Amendment. The decisive difference between Whitcomb and $R e$ gester was the plaintiffs' presentation of adequate evidence of intentional discrimination in the latter, and not in the former.

In turning to intentionality as the touchstone of a vote submersion claim, the Court treated these claims in a way that comports far better with communitarian than protective theories of democracy. Theories of protective democracy are, for the most part, unconcerned with questions of intent. Under a regime of protective democracy what counts is citizens' influence over the machinery of government, not the inten-

17 Id. at 149.

172 White v. Regester, 412 U.S. 755, 768 (1973).

${ }^{173}$ This, at least, is how the Court has retrospectively characterized Regester. See Mobile v. Bolden, 446 U.S. 55, $68-70$ (1980). Although the accuracy of this characterization is open to question, see, e.g., Hartman, supra note 167 , at 706, it makes little difference given the Court's holding in Bolden which explicitly required a showing of discriminatory purpose.

${ }^{174} 446$ U.S. at $66-70$. 
tions of governmental actors toward particular individuals or groups. The essence of an offense against protective democracy is the diminution of influence, whether intentional or not. ${ }^{175}$

This is not to say that intention plays no role whatsoever in theories of protective democracy. ${ }^{176}$ Even under protective democracy, the intentional deprivation of electoral influence may be worse than unintentional deprivations. For example, individuals or groups may be most in need of electoral influence precisely when the government intentionally discriminates against them in distributing the franchise. Such discrimination reveals an underlying hostility toward the disenfranchised group that could subsequently manifest itself in attacks on the group's rights and liberties, the preservation of which is the ultimate aim of protective democracy. In general, however, intentionality is not usually thought to be the hallmark of a protective democracy voting rights claim. ${ }^{177}$ Protective democracy works best, not as a justification for spot responses to specific problems of intentional governmental misbehavior, but as a permanent, broad framework for assuring political influence so as to prevent intentional governmental misbehavior from occurring in the first place.

In contrast, an intentionality requirement comports much better with a theory of communitarian democracy. The essence of an offense against communitarian democracy is exclusion-in this case, exclusion from the vote on the basis of race. Although it is certainly possible for

\footnotetext{
${ }^{175}$ Justice Marshall took this position in his dissent in Bolden. See id. at 108-12 (Marshall, J., dissenting).

${ }^{176}$ In a sense, protective democracy, particularly in its American version, is based on a presumption of intentional government misbehavior. In Madison's view, the abuse of government power by officials was inevitable. See THE FEDERALIST NO. 51 (James Madison).

${ }^{17}$ For example, John Hart Ely's theory of representation reinforcement, which relies heavily on notions of protective democracy, casts the federal courts in the role of assuring groups of adequate input into the political process. See JOHN HART ELY, DEMOCRACY AND DISTRUST: A THEORY OF JUDICIAL REVIEW 117 (1980) (stating that clearing access to the "democratic process is what judicial review ought preeminently to be about"). But there is nothing about this function that would limit courts' ability to look for barriers to participation that are erected deliberately. Ely is quite clear on this point. Where the right to vote is concerned,
}

[t]he Court's job ... is to look at the world as it exists and ask whether such a right is in fact being abridged, and if it is, to consider what reasons might be adduced in support of the deprivation, without regard to what actually occasioned it. To the extent that there is a stoppage, the system is malfunctioning, and the Court should unblock it without caring how it got that way.

$I d$. at 136 (footnote omitted). For a half-hearted attempt to suggest a reason why intent would be important to the resolution of protective democracy-based voting rights claims, see Larry Alexander, Last in the Political Thicket, 41 FLA. L. REV. 563, $565-67$ (1989). 
individuals or groups to be excluded from the vote unintentionallyfor example, as an unforeseen consequence of some facially neutral set of electoral procedures-any such exclusion is unquestionably worse when it is deliberate. Communitarian democracy is concerned not with citizens' privileges, 'but with their sense of belonging; what matters is that individuals and groups be treated, and understand themselves to be treated, in every respect as full members of society. While it might be possible for generous and good-natured citizens to continue to feel like full members of society even after suffering some kind of exclusion as an unintended consequence of a nominally benign policy, they cannot possibly feel like full members of society when their fellow citizens band together and exclude them intentionally, in an act of deliberate discrimination. ${ }^{178}$ For these reasons, the Court's conclusion that minority submersion claims are cognizable only in the presence of intentional racial discrimination ${ }^{179}$ suggests strongly that the Court understood the claims in these cases to embody a communitarian view of the significance of voting.

Ironically, however, not even the Court's turn to intentionality could insulate it from the underlying protective democracy aspects of the plaintiffs' claims in these cases. Our legal system does not generally recognize the possession of bad intentions as a cognizable legal offense; some kind of harm is also required. ${ }^{180}$ Unless the Court was willing to recognize the manifestation of a racially based intent to exclude as sufficient harm in itself to violate the Constitution-a position it has always resisted $^{181}$-some harm would have to be found. The plaintiffs, of

${ }^{178}$ One might even argue that "exclusion," in the communitarian sense, can only occur intentionally. The goal of communitarian democracy is recognition as a citizen, but recognition depends necessarily on the state of mind of others. To be something less than a full citizen is by definition to be an object of scorn, or at least of indifference. Thus, if something is important enough to serve as an indicium of full citizenship (such as voting) then its deprivation can only be "intentional" in a communitarian sense. In other words, it is impossible to deny any person standing as a full citizen in any way other than deliberately. On this view, the Court's Fifteenth Amendment jurisprudence is confusing because it focuses on intent rather than exclusion, yet in the end they amount to the same thing.

173 See supra note 174 and accompanying text.

180 See generally MODEL PENAL CODE, Art. 2 (1985).

131 See, e.g., Palmer v. Thompson, 403 U.S. 217, 224 (1971) ("[N]o case in this Court has held that a legislative act may violate equal protection solely because of the motivations of the men who voted for it"); see also Washington v. Davis, 426 U.S. 229, 240 (1976) (requiring "invidious quality" as well as a "racially discriminatory purpose"); Keyes v. School Dist. No. 1, 413 U.S. 189, 203 (1973) (requiring school segregation as well as intentional state action to support the finding of a dual system requiring an affirmative duty to desegregate the school system). It is possible however, to characterize Gomillion $v$. 
course, argued all along that the harm they had suffered was the degradation of their ability to use the political system to protect themselvesa protective democracy harm.

Surprisingly, the Court never for a moment questioned this definition of the relevant harm. In Regester, for example, the Court remedied the discriminatory exclusion of the plaintiffs not by attempting to craft some solution that would integrate blacks and Mexican-Americans into the political life of Dallas and Bexar Counties, ${ }^{182}$ but by ordering the breakup of the multimember districts into single-member districts ${ }^{183}$ that is, by giving these groups the political influence they sought. In this way, the Court inadvertently smuggled a significant protective democracy component into a case it was trying to treat as communitarian.

This tension in the right-to-representation cases lay dormant for some time, probably because it was obscured by the overwhelmingly racial nature of the cases. It came clearly into view, however, in the area of political gerrymandering, which lacked the usual overtones of racial bigotry.

\section{Political Gerrymandering}

Political gerrymandering is surely among the most difficult problems in voting rights jurisprudence. ${ }^{184}$ The Court's only decision in this area is Davis v. Bandemer, ${ }^{185}$ in which members of the Indiana Democratic Party challenged Indiana's 1980 redistricting plan, enacted by a Republican-controlled legislature and signed by a Republican gover-

Lightfoot, 364 U.S. 339 (1960), as such a case. See supra Part II.A.2.

${ }_{182}$ Cf. Brown v. Board of Educ., 347 U.S. 483 (1954).

${ }^{18 s}$ See White v. Regester, 412 U.S. 755, 765 (1973) (affirming the district court's judgment "insofar as it invalidated the multimember districts in Dallas and Bexar Counties and ordered those districts to be redrawn into single-member districts").

${ }^{184}$ Political gerrymandering has been termed the "thickest thicket" by Peter Schuck. See Schuck, supra note 14 , at 1325 . There are several reasons for focusing on political rather than racial gerrymandering. First, the law of racial gerrymandering has been dominated since 1965 by the Voting Rights Act, which complicates the analysis. Second, the few pre-Voting Rights Act cases make clear that intentional racial gerrymandering will be treated as a communitarian offense. See Gomillion v. Lightfoot, 364 U.S. 339 (1960), and discussion supra Part II.A.2. Third, claims of unintentional racial and political gerrymandering raise problems that are not significantly distinct. See Daniel H. Lowenstein \& Jonathan Steinberg, The Quest for Legislative Districting in the Public Interest: Elusive or Illusory?, 33 UCLA L. REV. 1, 5-6 (1985) (noting that "the definition and recognition of racial gerrymandering is beset by some of the methodological problems we identify in connection with political gerrymandering").

${ }^{185} 478$ U.S. 109 (1986). 
nor. ${ }^{186}$ The challenge focused on the way in which the legislature had drawn district lines and mixed single-member and multimember districts. ${ }^{187}$ As a result of this plan, the plaintiffs charged, Democratic candidates for the state House of Representatives won only $43 \%$ of the seats despite winning $52 \%$ of the statewide vote. ${ }^{188}$ In Marion and Allen Counties, which include Indianapolis, Democratic candidates attracted $47 \%$ of the vote, but won only 3 of 21 House seats. ${ }^{189}$ Additional evidence showed that Republicans openly admitted that their principal purpose in the reapportionment process had been to maximize Republican victories in a state in which voters were nearly evenly divided between Republicans and Democrats. ${ }^{190}$ The plaintiffs challenged the Republicans' intentional minimization of Democratic voting strength.

The Court's approach ${ }^{191}$ to these claims largely followed its approach in the earlier right-to-representation cases involving multimember districts. $^{192}$ The plaintiffs, apparently assuming that the Court would apply an intentionality standard, took pains to provide ample evidence of deliberate discrimination against them. ${ }^{193}$ The Court not only accepted the lower court's factual finding of intentional discrimination against Democrats, ${ }^{194}$ but also came close to holding that intentional discrimination against political opponents can be virtually assumed in the political power struggles of reapportionment. ${ }^{105}$

${ }^{180}$ See id. at 113-15.

${ }^{187}$ See id. at 115 ("Specifically, they contended that the particular district lines that were drawn and the mix of single-member and multimember districts were intended to and did violate their right, as Democrats, to equal protection under the Fourteenth Amendment.").

iss See id.

${ }^{189}$ See id.

${ }^{100}$ See id. at 114 n.1, 116-17 (concluding that the facts "evidenced an intentional effort to favor Republican incumbents and candidates and to disadvantage Democratic voters").

191 Although a majority found political gerrymandering justiciable, only a plurality of four Justices adhered to the principal analysis. I shall nevertheless treat this as the Court's analysis because its reasoning seems never to have been questioned by subsequent Court majorities, and because it is possible to read the other opinions as giving the plurality a fifth vote on the critical issues. See Daniel Hays Lowenstein, Bandemer's Gap: Gerymandering and Equal Protection, in POLITICAL GERRYMANDERING AND THE COURTS 64, 91, 95 (Bernard Grofman ed., 1990) (arguing that the plurality's reasoning was accepted by a majority of the Court).

${ }^{192}$ The Court went out of its way to note its reliance on the multimember, racial discrimination cases, and to stress the similarity of the relevant legal standards. See Bandemer, 478 U.S. at 131 n.12 \& 132 n.13.

${ }^{193}$ See id. at 115.

${ }^{19}$ See id. at 127.

${ }^{195}$ See id. at 128-29 ("As long as redistricting is done by a legislature, it should not be 
At this point, however, the question of harm came forcefully into view. Although the plaintiffs had framed their case to meet an intentionality standard, there was no escaping the fact that, as in the multimember district cases, the harm they claimed was to their protective democracy interests. Indeed, their claim appealed to theories of protective democracy on two levels: the plaintiffs claimed not only that the Republicans had made it difficult for Democrats to use the political system to protect their interests, but also that the districting legislation perpetuated that very danger by assuring future Republican control of the apparatus of government. ${ }^{196}$

Here the Court found itself trapped between its dislike for protective democracy-based claims on the one hand and the reliance on protective harms implicit in its communitarian approach on the other. The Court responded with a compromise that could have pleased no one: it held that the protective harms pled by the plaintiffs were constitutionally cognizable, but that the plaintiffs had not shown that they had actually been harmed in the way they claimed. ${ }^{197}$ The Court reached this conclusion by holding that an allegation of harm to a political party through a discriminatory reapportionment could not be proved by examining the results of a single election following the reapportionment; ${ }^{198}$ such harm could be shown only by demonstrating a consistent pattern of electoral defeat. Of course, this definition may well foreclose political gerrymandering claims: by the time a minority party has waited out two or three elections following the implementation of a reapportionment plan and then spent several years in complex litigation challenging the plan, the next decennial reapportionment will likely have arrived. Thus, the Court's recognition of protective democracy harms may be mostly theoretical. ${ }^{19 y}$

very difficult to prove that the likely political consequences of the reapportionment were intended.").

${ }^{196}$ See id. at 116-17; see also Schuck, supra note 14, at 1327-28, 1337-38 (discussing diminished legitimacy and self-perpetuation in power as reasons for considering political gerrymandering improper).

${ }^{197}$ See Bandemer, 478 U.S. at 143 (stating that "a threshold showing of discriminatory vote dilution is required for a prima facie case of an equal protection violation" and that such a threshold had not been reached).

${ }^{199}$ See id. at 135.

199 See Terrazas v. Slagle, 789 F. Supp. 828, 833 (W.D. Tex. 1991) (3-judge court) (noting that the Bandemer Court "offered little hope that political plaintiffs might prevail" on claims of political gerrymandering). Research uncovered only one case since Bandemer in which plaintiffs prevailed on a political gerrymandering claim, but that judgment was recently vacated for reconsideration in light of new evidence from the 1994 elections. See Republican Party v. Hunt, No. 88-263-CIV-5-F, 1994 U.S. Dist. LEXIS 19962 (E.D.N.C. 
D. The Court's Newfound Hostility Toward Section 2 of the Voting Rights Act

In a series of recent cases, the Supreme Court has expressed increasing hostility toward section 2 of the Voting Rights Act, ${ }^{200}$ and has hinted none too subtly that it might eventually strike down section 2 on constitutional grounds. ${ }^{201}$ The Court's hostility toward protective democracy-based voting rights claims, as demonstrated above, helps to explain this development. In this Section, I argue that the Court dislikes section 2 because the 1982 amendments to that provision implemented a protective-democracy solution to a problem that the Court defines as communitarian.

\section{The Voting Rights Act of 1965}

Congress enacted the Voting Rights Act in 1965 under its power, conferred by section 2 of the Fifteenth Amendment, ${ }^{202}$ to enforce the Fifteenth Amendment's command that the right to vote "shall not be denied or abridged by the United States or by any State on account of race [or] color." ${ }^{203}$ As originally enacted, section 2 of the Voting Rights Act closely tracked the language of the Fifteenth Amendment: "No voting qualification or prerequisite to voting, or standard, practice or procedure shall be imposed or applied by any State or political subdivision to deny or abridge the right of any citizen of the United States to vote on account of race or color."204

When the Court first encountered the Voting Rights Act in South Carolina v. Katzenbach, ${ }^{205}$ a broad-based challenge to the entire statutory scheme, the Court enthusiastically upheld the Act in its entirety. "Congress," the Court said, "felt itself confronted by an insidious and pervasive evil which had been perpetuated in certain parts of our country through unremitting and ingenious defiance of the Constitution." ${ }^{206}$ The Court then reviewed some of the most egregious examples of

Nov. 3, 1994), remanded, No. 94-2410, 1996 U.S. App. LEXIS 2029 (4th Cir. Feb. 12, 1996). ${ }^{200} 42$ U.S.C. $\$ 1973$ (1994).

201 See Miller v. Johnson, 115 S. Ct. 2475 (1995); Shaw v. Reno, 113 S. Ct. 2816 (1993). But see Bush v. Vera, 116 S. Ct. 1894 (1996) (four Justices willing to implicitly assume the constitutionality of section 2 ).

${ }^{202}$ U.S. CONST. amend. XV, $\$ 2$ ("The Congress shall have power to enforce this article by appropriate legislation.").

${ }^{200}$ Id. $\S 1$.

${ }^{204}$ Voting Rights Act of 1965, Pub. L. No. 89-110, $\$ 2,79$ Stat. 437, 437 (codified as amended at 42 U.S.C. $\$ 1973$ (1994)).

${ }^{205} 383$ U.S. 301 (1966).

Id. at 309 . 
overt, racially discriminatory state and local efforts to avoid registering black voters. ${ }^{207}$ These examples, the Court held, amply justified Congress's exercise of its power under the Fifteenth Amendment, and the Act itself was "a valid means for carrying out the commands of the Fifteenth Amendment."

Here we are confronted with an ambiguity: what exactly were the "commands of the Fifteenth Amendment" that the Voting Rights Act carried out? The Fifteenth Amendment prohibits racial discrimination in voting-but why? Is the purpose of the Fifteenth Amendment to assure blacks the ability to influence government for the purpose of protecting their rights and liberties? Does it, in other words, serve a theory of protective democracy? Or does the Fifteenth Amendment prohibit discrimination in voting for communitarian reasons-to end a stinging affront to blacks caused by their exclusion from the electoral process, and to embrace them officially as full members of American society? Might both rationales underlie the Fifteenth Amendment?

The Court found it unnecessary to address these questions in South Carolina $v$. Katzenbach, and indeed the question never had to be addressed by anyone so long as Voting Rights Act enforcement focused, as it did for many years, on eliminating the most obvious, intentional, and discriminatory efforts to disenfranchise blacks. ${ }^{209}$ Because such discrimination both excludes blacks from the political process and undermines their ability to protect their liberties through the electoral process, no need to distinguish between these two impacts arose.

\section{The Communitarian Fifteenth Amendment}

In 1980, the Court finally confronted this latent ambiguity. City of Mobile $v$. Bolden ${ }^{210}$ involved a challenge to the at-large system of municipal elections used by Mobile, Alabama. Under Mobile's system, the city was governed by a City Commission consisting of three members, each of whom was elected at large. ${ }^{211}$ The plaintiffs, black voters who lived in

${ }^{207}$ See id. at 310-13.

${ }^{203}$ Id. at 337.

${ }^{200}$ See Armand Derfner, Vote Dilution and the Voting Rights Act Amendments of 1982, in MiNORITY VOTE DILUTION 145, 150 (Chandler Davidson ed., 1984) ("The initial focus of efforts under the act was on registration and voting, through suspension of literacy tests."); GUINIER, TYRANNY, supra note 29, at 212 n.58 ("The initial structure of the Act itself focused on the suspension of literacy tests, the deployment of federal registrars, and federal administrative review of local registration procedures in covered jurisdictions.").

${ }^{210} 446$ U.S. 55 (1980).

211 See id. at 59-60. 
Mobile, charged that this at-large voting scheme violated their rights under the Fourteenth and Fifteenth Amendments, as well as section 2 of the Voting Rights Act, because the scheme prevented the plaintiffs for all practical purposes from electing candidates of their choice to the Commission. The Court, however, rejected all three challenges, with a four-Justice plurality providing the dominant reasoning. ${ }^{212}$

Crucial to the plurality's analysis was the factual finding of the district court that "Negroes in Mobile 'register and vote without hindrance." 219 From this and other evidence, the plurality concluded that the plaintiffs had not shown a violation of the Fifteenth Amendment because they had failed to produce any evidence that either the repeated losses of black-supported candidates or the city's continued maintenance of the at-large election system resulted from intentional racial discrimination. ${ }^{214}$ As we have seen, this kind of reliance on intentional discrimination is far more consistent with communitarian than with protective notions of democracy, and the Court's decision thus strongly aligns the Fifteenth Amendment with a communitarian definition of the harm suffered by blacks whose right to vote is infringed.

After interpreting the Fifteenth Amendment, the Court in Bolden went on to consider the plaintiffs' claim under section 2 of the Voting Rights Act. Because Congress had enacted the Voting Rights Act to enforce the Fifteenth Amendment, and because the language of section 2 essentially tracks the language of the Fifteenth Amendment, the Court concluded that section 2 should be read identically. ${ }^{215}$ Consequently, the Court interpreted section 2 to reach only intentional discrimination in the distribution of the franchise. ${ }^{216}$ Read together, the Court's decisions in City of Mobile v. Bolden and South Carolina v. Katzenbach thus describe a section 2 that provided a communitarian remedy to a commu-

${ }^{212}$ A majority of the Court later ratified the plurality's analytical approach in Rogers $v$. Lodge, 458 U.S. 613,616 (1982), but the Court there sustained the challenge to the atlarge voting scheme because the lower courts properly found the scheme was maintained for a discriminatory purpose. See id.

${ }_{213}$ Bolden, 446 U.S. at 65 (quoting the district court without citation).

214 See id. In so holding, the Court brought its Fifteenth Amendment jurisprudence into agreement with its equal protection jurisprudence as articulated in Washington $v$. Davis, 426 U.S. 229, 239 (1976) (rejecting a disparate impact theory of equal protection and holding that a showing of intentional discrimination is necessary to make out a violation of the implicit equal protection guarantee of the Fifth Amendment's Due Process Clause).

${ }^{213}$ See Bolden, 446 U.S. at 61 (noting that section 2 was "intended to have an effect no different from that of the Fifteenth Amendment"; it "simply restated the prohibitions already contained in the Fifteenth Amendment").

${ }^{216}$ See id. at 61-65 (discussing the Court's Fifteenth Amendment jurisprudence). 
nitarian problem, thereby assuring the provision's constitutionality.

\section{The 1982 Amendments and the Protective Solution}

Congress significantly disturbed this symmetry in 1982, when it amended section 2 for the express purpose of overturning the result in Bolden. ${ }^{217}$ The amendment changed section 2 to provide:

No voting qualification or prerequisite to voting or standard, practice or procedure shall be imposed or applied by any State or political subdivision in a manner which results in a denial or abridgement of the right of any citizen of the United States to vote on account of race or color ....

Congress went on to define a violation of this revised standard to include a showing that members of a group protected by the Act "have less opportunity than other members of the electorate to participate in the political process and to elect representatives of their choice. ${ }^{219}$ In construing this language in Thomburg $v$. Gingles, the Supreme Court held that, under the revised section 2, "a violation could be proved by showing discriminatory effect alone," and that Congress intended section 2 to establish a "results test."220

The significance of these changes can hardly be overstated. The focus of a section 2 inquiry suddenly shifted dramatically from the subjective intentions of the government to the impact of voting.procedures on the political influence of the group claiming discrimination. According to the Court, resolution of section 2 claims would now require examination of factors such as the extent of racially polarized voting in the district; exclusion of members of the minority group from the process of candidate slating; the extent to which past discrimination against members of the minority group in education, employment and health care has "hinder[ed] their ability to participate effectively in the political process"; "221 "the extent to which members of the minority group have been elected to public office in the jurisdiction"; ${ }^{222}$ and the

${ }^{217}$ See Thornburg v. Gingles, 478 U.S. 30, 43-44 (1986) (discussing the legislative history of the 1982 amendments).

${ }_{218}$ Voting Rights Acts Amendments of 1982, Pub. L. No. 97-205, § 3, 96 Stat. 131, 134 (codified as amended at 42 U.S.C. $\$ 1973($ a) (1994)) (emphasis added).

${ }^{219} I d$. (codified at 42 U.S.C. $\$ 1973(\mathrm{~b})$ ).

${ }_{220}$ Gingles, 478 U.S. at 35 . The results test in question was one that, according to Congress, the Court had articulated in White v. Regester, 412 U.S. 755 (1973). See id.

${ }^{221}$ Gingles, 478 U.S. at 37.

${ }^{222}$ Id. 
responsiveness of elected officials to the needs of the minority group. ${ }^{223}$ The Court also held that in order to prevail on a vote-dilution claim involving multimember districts, members of the complaining minority would have to prove "substantial difficulty electing representatives of their choice."

This analysis suggests strongly that Congress did more in the amended section 2 than merely change the standard for a violation: it changed to a considerable degree the conception of democracy on which the statute was based, from communitarian to protective. Under the new section 2, the measure of a violation is no longer simply exclusion from the political process; now, the measure of a violation is exclusion from the political process that impairs the political fortunes of the excluded group. The inability to nominate candidates, elect officials, or to secure a responsive hearing from those elected are all factors that reflect a group's lack of political influence, and hence its vulnerability-they are the kind of factors, in other words, that one would expect to be relevant under a theory of protective democracy.

This need not mean, of course, that communitarian factors play no role under section 2. First, as we shall see at further length in Part IV, there is no unbreachable dividing line between communitarian and protective theories of democracy. A group's inability to influence the political process may also reflect the kind of exclusion from social grace that offends communitarian conceptions of democracy. Second, some of the other factors identified by the Court as relevant to establishing a section 2 violation - a history of racial discrimination in the district, racially polarized voting, and the use of racial appeals in political campaigns, ${ }^{225}$ to name a few-sound more in communitarian than in protective theories of democracy. Third, the Court took pains to point out that a section 2 violation is not established by any particular formula, but by a totality of the relevant circumstances. ${ }^{226}$

For these reasons, it is plausible to view the amended section 2 as guided, at least in part, by a mix of communitarian and protective conceptions. Which conception is dominant, then, may depend heavily on which factors are emphasized in the section 2 analysis. The more the analysis emphasizes discrimination and exclusion, the more communitarian it is; the more the analysis emphasizes electoral influence and

\footnotetext{
223 See id.

224 Id. at 51 n.15.

223 See id. at $44-45$.

${ }^{226}$ See id. at $45-46$.
} 
success, the more protective. As courts and commentators have widely noted, Voting Rights Act enforcement since 1982 has been dominated increasingly by an emphasis on the electoral success of minority groups. ${ }^{227}$ Indeed, in Gingles, Justice O'Connor went so far as to accuse the majority of creating "an entitlement to roughly proportional representation. ${ }^{228}$ This is exactly the development that has most troubled the Court: the ascendance of a protective-democracy reading of section 2 and the concomitant application of protective-democracy solutions to problems that the Court defines as communitarian.

\section{The Court's Hostile Reaction}

In its first confrontation with the amended version of section 2 , in Thomburg $v$. Gingles, the Court gave no sign of any dissatisfaction with the provision; it confined itself to interpreting section $2 .^{229}$ It was not until 1993, in Shaw v. Reno, ${ }^{290}$ that the Court's attitude toward the Voting Rights Act began to shift dramatically. Shaw concerned the legality of North Carolina's 1990 redistricting plan in which, under pressure exerted by the Justice Department under section 5 of the Voting Rights Act, the State created a majority-black district of a highly unusual, elongated shape. The plaintiffs claimed that the district's "bizarre",231 shape

${ }^{227}$ See Holder v. Hall, 512 U.S. 874, 900 n.7 (1994) (Thomas, J., concurring) ("[I]t should be clear that the assumptions that have guided the Court reflect only one possible understanding of effective exercise of the franchise, an understanding based on the view that voters are 'represented' only when they choose a delegate who will mirror their views in the legislative halls."); Gingles, 478 U.S. at 93 (O'Connor, J., concurring) ("[E]lectoral success has now emerged, under the Court's standard, as the linchpin of vote dilution claims."); City of Carrolton Branch of the NAACP v. Stallings, 829 F.2d 1547, 1562 (11th Cir. 1987) (referring to minority electoral success as "most important to a vote [dilution] claim"), cert. denied, 485 U.S. 936 (1988); Collins v. City of Norfolk, 816 F.2d 932, 937 (4th Cir. 1987) (remanding to determine "minority electoral success" and defining that term); Jackson v. Edgefield County, S.C. Sch. Dist., 650 F. Supp. 1176, 1200 (D.S.C. 1986) (referring to minority electoral success as one of the two most important factors in a section 2 case); ABIGAIL M. THERNSTROM, WHOSE VOTES COUNT? passim (1987); Abrams, supra note 45 , at 507 (stating that within the "totality of circumstances" test, "past electoral performance of the plaintiff group has gained importance"); Samuel Issacharoff, Polarized Voting and the Political Process: The Transformation of Voting Rights Jurisprudence, 90 MICH. L. REV. 1833, 1852 (1992) (stating that the Gingles standard requires that plaintiffs show that a "pattern of bloc voting by the majority community has, over time, generally led to the defeat of minority-supported candidates").

${ }^{228}$ Gingles, 478 U.S. at 93 (O'Connor, J., concurring); cf. Johnson v. De Grandy, 512 U.S. 997, 1026 (1994) (O'Connor, J, concurring) (commending the Court for holding that evidence of minority electoral success is always relevant, but never dispositive).
229478 U.S. 30 (1986).
2300 U.S. 630 (1993).
$2: 1$. at 644 . 
showed that the State had drawn the district lines for racial reasons, and that this race-consciousness in apportionment violated their Fourteenth Amendment right "to participate in a 'color-blind' electoral process." Surprisingly, the Court proved highly receptive to this claim. ${ }^{233}$ Calling North Carolina's race-conscious districting a form of "political apartheid," ${ }^{234}$ the Court remanded the case for full adjudication of the plaintiffs' claims. ${ }^{235}$

The Court explained and refined the holding of Shaw two years later in Miller v. Johnson, a factually similar case from Georgia. It held that the claim recognized in Shaw was a claim that "the State has used race as a basis for separating voters into districts." ${ }^{237}$ Applying strict scrutiny, the Court said that a plaintiff can prevail on such a claim by showing "that race was the predominant factor motivating the legislature's decision to place a significant number of voters within or without a particular district."288 The districting at issue in Miller failed this analysis because the State created the district not to remedy past discrimination, but "to satisfy the Justice Department's preclearance demands" for a third majority-black district in Georgia. ${ }^{239}$ These demands, made by the Justice Department pursuant to its authority under the Voting Rights Act, did not provide the State with a compelling justification for its districting plan: "compliance with federal antidiscrimination laws cannot justify race-based districting where the challenged district was not reasonably necessary under a constitutional reading and application of those laws." ${ }^{240}$

These rulings suggest that one of two things is wrong with Voting Rights Act enforcement as currently practiced by the Justice Depart-

${ }^{232} I d$. at $641-42$.

${ }^{23 s}$ Commentary on the Court's opinion has been extensive. See, e.g., Bierstein, supra note 37, at 1459; Emily Calhoun, Shaw v. Reno: On the Borderline, 65 U. COLO. L. REv. 137, 148-49 (1993); Samuel Issacharoff \& Thomas C. Goldstein, Identifying the Harm in Racial Gernymandering Claims, I MICH. J. RACE \& L. 47 (1996); Pamela S. Karlan, All Over the Map: The Supreme Court's Voting Rights Trilogy, 1993 SUP. CT. REV, 245, 246; Lisa A. Kelly, Race and Place: Geographic and Transcendent Community in the PastShaw Era, 49 VAND. L. REV. 227, 235 (1996); Symposium, The Future of Voting Rights After Shaw v. Reno, 92 MrCH. L. REV. 483 (1993); Symposium, Voting Rights After Shaw v. Reno, 26 RuTGERS L.J. 517 (1995); Voting Rights Symposium, 3 D.C. L. REv. 1 (1995).
${ }^{234}$ Shaw, 509 U.S. at 647.
235 See id. at 658.
115 S. Ct. 2475 (1995).
${ }^{237}$ Id. at $2485-86$.
${ }^{238}$ Id. at 2488.
299 Id. at 2489.
240 Id. at 2490 . 
ment: either the Justice Department has misconstrued section 2 to authorize the race-conscious creation of majority-minority districts for the purpose of increasing minority representation; or the Department has correctly construed the statute and it is unconstitutional. In either case, the Court's ultimate goal seems to be to prune section 2 back to its 1965 limits. This is a striking development, for it not only threatens the Court's important holding in Katzenbach v. Morgan ${ }^{241}$ that Congress has the power to define civil rights violations more expansively than does the Constitution itself, but also represents a determination that the Fourteenth Amendment acts as a limit on the Fifteenth Amendment. Aside from the counterintuitive proposition that earlier amendments can limit later ones, such a reading seems to make the Fifteenth Amendment almost completely redundant since the Court has construed the Fourteenth Amendment to limit intentional racial discrimination in any matters, including, it would seem, voting. ${ }^{242}$

The question of section 2's constitutionality, considered only obliquely and by implication in Shaw and Miller, came forcefully into the open last term in Bush $v$. Vera, ${ }^{243}$ a highly splintered decision invalidating three congressional districts in Texas. Despite Justice O'Connor's passionate defense of the lukewarm position that section 2 should for now be presumed constitutional, ${ }^{244}$ five Justices seem to agree that the course undertaken in Shaw leads inevitably to section 2's invalidation. ${ }^{245}$ Although the Court's movement toward invalidating the 1982 amendments to the Voting Rights Act comports at best uncomfortably with some of its earlier rulings under the Fourteenth and Fifteenth Amendments, its position in the Shaw line of cases comports quite well with the Court's longstanding hostility to protective democ-

241384 U.S. 641 (1966).

${ }^{242}$ See Emma Coleman Jordan, Taking Voting Rights Seriously: Rediscovering the Fifteenth Amendment, 64 NEB. L. REV. 389 (1985) (arguing that the Court has improperly ignored the Fifteenth Amendment); Grier Stephenson, Jr., The Supreme Court, the Franchise, and the Fifteenth Amendment: The First Sixty Years, 57 UMKC L. REV. 47 (1988) (same).

243116 S. Ct. 1941 (1996) (plurality opinion).

${ }^{244}$ Id. at 1969-70 (O'Connor, J., concurring). The plurality of Justice O'Connor, Chief Justice Rehnquist and Justice Kennedy also was implicitly willing to assume the Act's constitutionality. Id. at 1961 (O'Connor, J., concurring).

${ }^{245}$ Justices Thomas and Scalia took the position that the intentional creation of any majority-minority district requires strict scrutiny. Id. at 1972 (Thomas, J., concurring). In light of their positions in Adarand Constructors, Inc. v. Pena, 115 S. Ct. 2097 (1995), it is difficult to view their position in Bush as anything other than a prelude to declaring section 2 unconstitutional. In their dissent in Bush, Justices Souter, Ginsburg and Breyer argued that pursuit of Shaw's logic leads ultimately to declaring the Voting Rights Act unconstitutional. See Bush, 116 S. Ct. at 2010, 2011 (Souter, J., dissenting). 
racy-based voting rights claims. In setting itself against the use of section 2 as a vehicle for the expansion of the political influence of racial minorities, the Court may be merely extending a line it has already staked out between permissible communitarian-based and impermissible protective-based justifications for enforcing the right to vote.

\section{REASONS FOR THE COURT'S PREFERENCES}

The previous Part demonstrated that, in many cases, in many different contexts, the Court has expressed a general hostility toward voting rights claims based on theories of protective democracy and a correspondingly greater receptiveness to voting rights claims based on theories of communitarian democracy. These preferences may be rough-they may not come through clearly or uniformly in every case-but the pattern is there. The next question is: Why? What accounts for these preferences?

In this Part, I argue that the inherent logic of a protective democracy-based voting rights claim forces the Court to do something that it has never wanted to do: commit itself to the principle that the Constitution creates a definite, judicially discernible structure for the exercise of popular political power. The reasons the Court has historically given for wanting to avoid this task go to its view of its own competence. Another reason, however, may well be that the Court wishes to avoid publicly pronouncing the unappealing conclusion that the Constitution provides Americans with a level of political influence that is not merely minimal, but unacceptable by contemporary standards of democratic self-government.

In comparison, communitarian theories of democracy look far more attractive, and the assertion of such theories has allowed the Court to make an end run around the features of protective democracy that it finds unattractive. Rather than relying on constitutionally established baselines of political influence, the Court has used communitarian-based claims as a vehicle for turning to American community understandings and democratic traditions-understandings and traditions that are far more democratic than the actual constitutional structure of politics.

Finally, this Part concludes by examining the ways in which the Court's designation of the Equal Protection Clause as the primary repository of constitutionally protected voting rights has facilitated the Court's substitution of communitarian for protective concepts of democracy. 


\section{A. The Logic of Protective Democracy-Based Voting Rights Claims}

\section{The Conceptual Structure of the Claim}

The essence of a protective democracy-based voting rights claim is a claim of inadequate political influence. The claimant says, in effect, "My ability to influence the political process is inadequate; as a consequence, I am unable adequately to protect my rights and liberties." This formulation immediately raises a critical question: how much influence over the political process is "adequate"? The purpose of protective democracy is, after all, to allow citizens to protect themselves. This kind of protection requires political power. To respond to a protective democracy-based voting rights claim, then, we must know the degree of political power to which citizens are entitled under a protective democracy regime.

A useful starting point for answering this question is provided by political scientist Robert Dahl. According to Dahl, one of the criteria that citizens of liberal democracies use to evaluate the acceptability of forms of governance is the "Criterion of Personal Choice." Dahl means that any individual member of society will tend to prefer a social decisionmaking process that results as often as possible in outcomes that correspond to the individual's personal preferences. ${ }^{247} \mathrm{Dahl}$ points out, however, that the Criterion of Personal Choice clearly cannot be satisfied for everyone in every instance, and some kind of compromise must be accepted if life in organized society is to continue. If individual political influence is measured as the ability to secure desired political outcomes, then every regime gives its citizens a degree of influence ranging from no influence at all-as, for example, under a dictatorship-to complete control-as where the citizen constitutes a polity of one. ${ }^{248}$ This analysis allows us to reformulate the question: if

${ }^{246}$ ROBERT A. DAHL, AFTER THE REVOLUTION? 6-9 (rev. ed. 1990).

${ }^{247}$ See id. at 6.

${ }^{243}$ For purposes of this discussion, I distinguish between the citizenry and the government. Thus, I will not consider a dictatorship to be a political arrangement in which one citizen has all the power and the other citizens have none. In so doing, I follow a fairly standard convention in political theory of distinguishing between the interests of government officials as officials and their interests as citizens. See, e.g., ARISTOTLE, POLIIICS, bk. III, ch. 7, at 1279a-1279b (Ernest Barker, trans., Oxford University Press 1995) (distinguishing among forms of government depending on whether the rulers pursue the common good or their own personal interest); THE FEDERALIST NOS. 10, 51 (James Madison) (postulating the pursuit of private interest as an inevitable prelude to attempts to institute governmental tyranny); see also HANNAH ARENDT, THE HUMAN CONDITION (1958) (tracing development of a private realm distinct from public life). 
protective democracy is to protect adequately, at what point on the spectrum between no control and absolute control over the substance of political decisionmaking is the line of compromise to be drawn?

At this point, it is tempting to make the following response: an "adequate" share of political influence is an equal share. ${ }^{245}$ Yet the move to equality does not answer the question posed, for there is no particular reason to suppose that an equal share of political influence will necessarily be an adequate share. A forty-ounce cake may provide each of ten people with a four-ounce slice, but it does not follow that a four-ounce slice of cake is nutritionally adequate. As in cooking, so in politics: to say that political influence must be distributed equally ${ }^{250}$ says nothing about how much influence is adequate to protect the rights and liberties of the citizenry. ${ }^{251}$ For example, in an absolute monarchy, ordinary citizens may have no influence at all on political decisionmaking. Their influence is equal-no one has any-but it is not adequate under any definition of adequacy that an American is likely to give. Similarly, Saudi Arabia is a monarchy, but the monarch rules subject to a tradition of freely granting audiences to individual subjects. ${ }^{252}$ If ac-

${ }^{249}$ In Dahl's account, the turn to political equality follows naturally from the recognition that the Criterion of Personal Choice cannot be satisfied for everyone. See DAHL, supra note 246 , at 8-9.

${ }^{230}$ Inequality of political influence is a concern only on the assumption that political influence must be distributed equally, an assumption by no means universally shared, even among advocates of democracy. For example, John Stuart Mill, a fierce advocate of universal suffrage under a regime of proportional representation, argued that the welleducated should be given extra votes to reflect their greater ability to contribute to good political decisionmaking. See MILL, supra note 45, at 334-37. Of course, there are substantial traditions in political philosophy arguing for the distribution of political influence on the basis of virtues that are concededly unequally distributed throughout society. See, e.g., ARISTOTLE, supra note 248, at bks. III-IV; PLATO, THE REPUBLIC bks. II-III.

Nevertheless, the assumption of human equality seems so fundamental to American political culture that an implicit equality requirement may be granted without controversy. The Declaration of Independence proclaims the equality of individuals a selfevident truth. See THE DECLARATION OF INDEPENDENCE para. 2 (U.S. 1776). Derivations of equality can be found in the work of many natural rights theorists, such as Hobbes and Locke. See THOMAS HobBES, LeviATHAN pt. I, ch.13 (Richard Tuck ed., 1991) (1651); LOCKE, supra note 49 , at ch. II.

${ }^{251}$ See Peter Westen, The Empty Idea of Equality, 95 HARV. L. REV. 537 (1982) (arguing that the rhetoric of equality should be abandoned as an explanatory norm); $o f$. C.B. MACPHERSON, Problems of a Non-Market Theory of Democracy, in DEMOCRATIC THEORY: ESSAYS IN RETRIEVAL 39, 55 (1973) (any fully democratic theory must assert that "the rights of any man which are morally justifiable on any egalitarian principle are only those which allow all others to have equal effective rights; and that those are enoug $h^{n}$ to achieve democracy's goals).

${ }^{252}$ See Douglas Jehl, In Uneasy Time, Saudi Prince Provides a Hope of Stability, N.Y. TIMES, Jan. 19, 1996, at Al. 
cess to these audiences is equal, and Saudi citizens can use their audiences to influence the King's decisions, then Saudi citizens have an amount of political influence that is equal, and which exceeds that of citizens of monarchies in which audiences are not granted, yet which Americans would surely consider inadequate.

Moving from monarchy to democracy does not alleviate this indeterminacy problem. A form of government might be democratic, but provide for legislative terms of twenty-five years. Legislators who are unlikely to stand for reelection in their lifetimes might be thought insufficiently responsive to the popular will to provide the people with adequate influence over the political process. ${ }^{253}$ Similarly, legislators in a democracy might or might not hold office subject to a requirement to obey instructions from their constituents. The people's influence over a Burkean legislature that rejects instructions in favor of the legislators' independent judgment might be thought by some to provide citizens with influence that is equal, but inadequate.

These examples make two things clear. First, protective democracy itself cannot determine the degree of political influence that provides citizens with an adequate level of protection. Protective democracy supplies a purpose for governmental organization, but not the form of organization. Second, the amount of protection that is adequate cannot be determined independently of the decision to adopt a particular form of government, thereby incorporating a particular method of exercising political influence. Indeed, when the assumptions of protective democracy are brought into play, the decision to adopt any particular form of government necessarily reflects a prior determination about the degree of citizen influence that is appropriate. In other words, when we operate within a framework of protective democracy, we choose a form of government because we think it provides citizens with an adequate degree of political influence and protection. Creating a particular political process thus establishes the amount of influence to be deemed adequate. Once that decision is made and a particular political process installed, citizens simply have such means of influencing the political process as the system by design provides, and the only remaining question is whether those means have in fact been appropriately distributed. The means of influence themselves, however, are deemed

${ }^{235}$ The Framers certainly thought so, which is why they stressed concepts such as frequent elections to the House of Representatives, rotation in office, and staggered senatorial terms. For an overview, see Neil Gorsuch \& Michael Guzman, Will the Gentlemen Please Yield? A Defense of the Constitutionality of State-Imposed Term Limitations, 20 HOFSTRA L. REV. 341, 345-53 (1991). 
adequate by definition. ${ }^{254}$

It follows that those who criticize a particular system of government for providing them with inadequate political influence can be saying one of two things. First, they may be criticizing the society's choice of governmental organization on the ground that it is badly designed in that it does not provide its citizens with an adequate amount of political influence. We may call this an "inadequate influence" claim. Second, they may be conceding the adequacy of political influence offered by the chosen system, but claiming that whatever means of influence that the system by design provides have been in practice denied to them. We may call this a "denial of influence" claim. In an inadequate influence claim, citizens criticize their political influence in absolute terms by comparing it to the amount of influence they would have under some other form of government offering some other, stronger opportunities to influence political outcomes. In a denial of influence claim, citizens criticize their political influence only relatively, by comparing the amount of political influence they actually have to the amount to which the existing political system entitles them.

Let us see how these kinds of claims might show up in voting rights litigation. The first thing to observe is that voting rights plaintiffs are highly unlikely to bring an inadequate influence claim directly. To claim that the existing political system provides citizens with an inadequate degree of political influence over the government is to criticize a foundational choice of governmental organization. Such choices are just the kind made by constitutions, and one can hardly expect to get a sympathetic judicial hearing on an overt claim that the Constitution makes a poor choice that should be judicially displaced. ${ }^{255}$

${ }^{254}$ Asking how much political influence is adequate is not unlike asking what counts as an "adequate" chance to win the lottery. Everyone who plays the lottery must have an equal chance to win because equality of chance is part of how we define lotteries. But knowing that everyone must have an equal chance to win says nothing about the kind of lottery that should be chosen. For example, we might choose a lottery format that offers low payoffs to many winners because we think, for reasons entirely independent of the lottery structure, that an "adequate" chance of winning the lottery means a comparatively decent chance to win something, no matter how small. Or we might choose a high-odds, high-payoff system because we think an "adequate" chance to win means any chance, no matter how slim, to win a very large sum. In either case, to choose a particular lottery format is to define the adequacy of the chance. Once that choice is made, those who criticize the lottery for offering them an inadequate chance to win are criticizing the original choice of lottery format rather than their own treatment under the chosen system.

${ }^{255}$ On the other hand, such a claim might well be addressed to a legislature if legislatures are constitutionally free to provide citizens with more influence than the state or federal constitutional minimum. See infra Part III.B.2.a. 
This is not to say that inadequate influence claims can never be brought, only that they must be disguised. Typically, such a claim will be couched as a contention about the kind of political system the Constitution actually implements. We would thus expect a litigant to mount this type of argument by making a claim about what the constitutionally mandated system "really" is-for example, that the Constitution, properly understood, establishes universal suffrage, or a mandatory system of proportional representation. Presumably, among the reasons that might be offered to support such a conclusion would be the argument that the Constitution, as interpreted by the plaintiff, provides an adequate degree of political influence to all citizens. Such an argument rests on an inference that interpretations of the Constitution providing citizens with more influence are to be preferred over those providing them with less influence. ${ }^{256}$

A denial-of-influence claim, on the other hand, would concede the constitutionally established political system as given, but argue on due process or equal protection grounds ${ }^{257}$ that the tools of political influence provided under that system have been unfairly denied to some. For example, denial-of-influence plaintiffs might claim that the constitutional system includes a general entitlement to the franchise, yet they have been denied the vote. ${ }^{258}$ Or they might claim that the Constitution requires a state's chief executive to be popularly elected, but the state provides only for legislative appointment of the Governor. ${ }^{259}$ Another such claim might be that the constitutional scheme requires allocation of the franchise to those directly governed by an elected body, but that the franchise has not been so extended. ${ }^{260}$

These examples also show that the two kinds of voting rights claims have a tendency to converge. This is because the denial-of-influence argument, like the inadequate influence argument, requires the litigant to take a position about the means of political influence that are actu-

${ }^{256}$ This is an appealing inference, but one the Court has rejected. See infra Part III.B.2.

${ }^{257}$ It can be seen from this analysis that a denial of influence claim is best conceived as a due process claim. To treat it as an equal protection claim would involve comparing the plaintiff's claim not to a substantive standard of influence set by the Constitution, but to the amount of influence in fact allocated to others. This issue is treated further below. See infra Part III.D.

${ }_{238}$ See, e.g., Lassiter v. Northampton County Bd. of Elections, 360 U.S. 45 (1959); Harper v. Virginia Bd. of Elections, 383 U.S. 663 (1966); Richardson v. Ramirez, 418 U.S. 24 (1974).

\footnotetext{
259 See, e.g., Fortson v. Morris, 385 U.S. 231 (1966).

${ }^{260}$ See, e.g., Holt Civic Club v. City of Tuscaloosa, 439 U.S. 60 (1978).
} 
ally provided by the constitutionally established political system. For example, denial-of-influence plaintiffs might concede that the Constitution provides for (or allows) winner-take-all districted elections, but argue that such a system, properly understood, "really" entitles them to a district in which they will be able to elect a representative of their choice. $^{261}$

\section{The Logic of Protective Democracy Exemplified: Three Theorists}

At this point, it may be useful to illustrate the logic of protective democracy claims with a few more thorough examples. In this Section, I shall focus on the arguments of three theorists who work much of the time within the protective democracy tradition: John Stuart Mill, Kathryn Abrams and Lani Guinier.

In addition to fleshing out the conceptual logic of protective democracy, the following discussion also demonstrates one of the advantages of locating claims about the right to vote in the broader context of theories of democracy: the ability to put seemingly disparate thinkers into direct dialogue with one another. Many of the most prominent debates in voting rights theory give the impression of clashes between wholly different and, in some cases, incommensurable conceptions of voting. Is the right to cast a ballot, standing alone, a meaningful right? Does the right to vote include a right to representation? Can a vote be considered effective even if it never results in governmental adoption of substantive policies preferred by the voter? Affirmative and negative positions on all these issues are easy to come by. Approaching the right to vote by way of democratic theory often allows us to make sense of these seemingly intractable debates by permitting theorists to engage, metaphorically speaking, in a more direct dialogue. This, in turn, has the valuable benefit of permitting a more precise identification of the real grounds of disagreement among them.

Examination of these theorists' views reveals that what divides them is not their theoretical beliefs about the purpose or significance of democracy, but their empirical assumptions about the ways in which political influence is exercised within a democratic regime. Protective democracy is premised on the need to protect, but the mechanisms by which citizens protect their interests necessarily depend upon the structure and operation of government. What secures influence in one regime may not do so in another. Ultimately, these theorists disagree

${ }^{201}$ But see, e.g., Davis v. Bandemer, 478 U.S. 109 (1986). 
only on the mechanisms by which citizens influence the workings of government. Whether their claims fall into the inadequate influence or denial-of-influence category thus depends on whether they believe the means for exercising adequate influence are already in place.

\section{a. Mill: Influence by Personal Persuasion}

John Stuart Mill is a good example of a theorist who makes an undisguised claim of inadequate influence under a regime of protective democracy. ${ }^{262}$ For Mill, the right to vote must mean the right to elect a representative to a legislature seated under a system of proportional representation. ${ }^{263}$ Mill's claim is clearly one of inadequate influence because it is an overt criticism of the British electoral system and a direct plea for change. ${ }^{264}$ Mill's conception of the right to vote does not rest on some metaphysical conception of the essential nature of voting, representation or democracy. Rather, working from a straightforward, traditional theory of protective democracy, Mill reaches his conclusions as a direct consequence of his assumptions about the way in which political influence is exercised in a democratic republic. In Mill's view, citizens exercise political influence by electing representatives who then attempt in the legislature to advance their constituents' beliefs.

Mill begins his defense of proportional representation with a flat rejection of the possibility of virtual representation: "the rights and interests of every or any person are only secure from being disregarded, when the person interested is himself able, and habitually disposed, to stand up for them." It follows that the "ideally best form of government" is a pure democracy in which citizens personally stand up for themselves. ${ }^{2653}$ Where pure democracy is impracticable, however, it falls to a person's representative to "stand up for" his or her interests.

Nevertheless, Mill is quite clear that standing up for one's interests is not the same as obtaining what one wants. He acknowledges that

${ }^{202}$ It may seem paradoxical to label Mill, usually taken to be a leading exponent of deliberative democracy, see supra note 45 , as a protective democracy theorist. In fact, as will become evident below, Mill's approach does not partake exclusively of either theory, but relies extensively on both. Here, I focus on the aspects of his thought that rely most heavily on traditions of protective democracy.

${ }_{263}$ See MILL, supra note 45 , at 303 ("In a really equal democracy, every or any section would be represented not disproportionately but proportionately.").

${ }^{264}$ See id. at 246-47 (disapproving the exclusion of the working classes, and their perspectives, from the English Parliament).

${ }^{265}$ Id. at 245 . For a useful discussion of why Mill's utilitarianism leads him to this conclusion, see PITKIN, supra note 38, at 202-06.

${ }^{266} \mathrm{MILI}$, supra note 45 , at 244. 
government requires some form of majority rule; it is perfectly proper, he says, that "the majority of the people, through their representatives, will outvote and prevail over the minority and their representatives." 267 Consequently, democracy is incapable of protecting all interests of all people at all times. ${ }^{269}$ It does not follow, however, that democratic government is consistent with the majority "blotting out the smaller number altogether." If democracy is to serve its elemental function of protecting the interests of the citizenry, it must afford citizens at least the opportunity, through their representatives, to stand up for themselves.

This position leads Mill to advocate a strict form of proportional representation, and to condemn as "false democracy" the kind of winner-take-all system with which Americans are familiar. ${ }^{270}$ People with rights must have those rights represented-stood up for-in the legislature itself. For this reason, Mill goes on to contend, in the strongest possible language, that those who vote for the losing candidate in a winner-take-all election are entirely "unrepresented." 271

Mill's position is vulnerable to a ready criticism: if the purpose of democracy is to protect the rights and interests of citizens, of what use is a voice in collective decisionmaking if one's voice is never heeded? How are my rights better protected by having a representative who is constantly outvoted in legislative decisionmaking than by having no representative at all? Mill seems to condemn false democracy only to offer a form of false representation.

Mill's response to this criticism rests on his belief that deliberation has the power to alter decisions. Although the minority, he concedes, "will necessarily be outnumbered, it makes a great difference whether or not they are heard." 272 The majority may always outvote the minority, but

${ }^{207} I d$. at 303.

${ }^{268}$ As political scientist Robert Dahl puts it, the desire of all citizens to get what they want-what Dahl calls the "Criterion of Personal Choice" -is in tension with the need to live in society. See DAHL, supra note 246 , at 6-9.

${ }^{269}$ MILL, supra note 45, at 303.

270 See id. at 303-07.

271 Id. at 305.

272 Id. at 313. It is not entirely clear whether Mill believes that a hearing always makes a difference, or whether that is the case only under the kind of proportional representation proposed by Hare which, in Mill's view, would tend to result in the selection of intelligent and virtuous representatives. See id. at 310-14. Mill's argument that the minority must be afforded a voice might lose some force if the minority's representatives were foolish, corrupt or inarticulate. 
they would speak and vote in their presence, and subject to their criticism. When any difference arose, they would have to meet the arguments of the instructed few, by reasons, at least apparently, as cogent; and since they could not, as those do who are speaking to persons already unanimous, simply assume that they are in the right, it would occasionally happen to them to become convinced that they were in the wrong. As they would in general be well-meaning ..., their own minds would be insensibly raised by the influence of the minds with which they were in contact, or even in conflict. ${ }^{273}$

Thus, for Mill, representation protects the represented by giving them a voice and an opportunity to convince others, even if the attempt to persuade is ineffective.

Mill's analysis contains a significant internal tension, for he may be read to call not for the representation of individuals or groups, but for the representation of viewpoints. On this reading of Mill, what ultimately protects a citizen's rights is the airing of the citizen's point of view in the legislature. As Hanna Pitkin has pointed out, however, "although there must be a representative for "every worthwhile opinion,' the number of representatives from each particular opinion is essentially irrelevant. If representing means presenting a point of view, one spokesman is as good as ten." ${ }^{274}$ Thus, the representative who presents the citizen's views need not be one for whom the citizen actually voted, nor must the citizen's views be represented in numbers sufficient to implement those views, or even in numbers proportional to the extent to which they are held. Consequently, the right to representation offered by Mill does not entitle groups or individuals to electoral success or even electoral influence, much less proportional representation, so long as some member of the legislature is willing to bring up the pertinent viewpoints at some point during the legislative debates.

This tension may be resolved by reading Mill's position more strongly. Mill's rejection of virtual representation and his stress on selfpromotion of citizens' interests may be taken to reveal an underlying belief that only a person's "own" representative-that is, one for whom the person has actually voted and over whom he or she thus exercises direct electoral influence-can be relied upon to raise, argue and defend the person's point of views in a satisfactory way. Thus, for Mill, the content of the right to vote in a properly constituted republic flows

279 Id. at 314.

274 PITKIN, supra note 38, at 83-84 (quoting A. Phillips Griffiths and Richard Wollheim, How Can One Person Represent Another?, 34 ARISTOTELIAN SOC'Y SUPP. 187, 212 (1960)). 
from the twin beliefs that representatives are adequately responsive only to those to whom they owe their election, and that an adequately motivated representative is capable of persuading other members of the legislature of the point of view of his or her constituents.

\section{b. Abrams: Multiple Channels of Influence}

One of Mill's key assumptions is that legislators are adequately responsive only to those to whom they directly owe their election. Yet the accuracy of this assumption is hardly self-evident; in view of the condition of politics in the contemporary United States, Mill's assumption seems charmingly naive. If not in Mill's society then in ours, there are many ways to influence elected officials: these include, for example, letter-writing, grass-roots organizing and, most effective of all, the judicious dissemination of money. ${ }^{275}$ Indeed, it is scarcely necessary to have the vote at all nowadays, for the best-represented interests on Capitol Hill and in state capitols are surely the interests of corporations and businesses that are not even eligible to vote. Even foreign nations with well-financed lobbying campaigns are often better represented today in the Millian sense than are American citizens whose only resource is their votes. ${ }^{276}$

If we relax Mill's assumption about the means by which citizens influence their representatives, we may simultaneously relax his conclusions about the necessary content of the right to vote. This is the approach taken by Kathryn Abrams in her writings on the Voting Rights Act ${ }^{277}$ According to Abrams, the Act's focus on the success of minority

${ }^{273}$ The role of money in politics has been well-documented. See, e.g., HERBERT E. ALEXANDER, FINANCING POLITICS: MONEY ELECTIONS, AND POLITICAL REFORM (4th ed. 1992); DAVID W. ADAMANY \& GEORGE E. AGREE, POLIMCAL MONEY 195-221 (1975). The contribution disclosure provisions of the Federal Election Campaign Act are predicated on the assumption that money talks. See Buckley v. Valeo, 424 U.S. 1, 60-84 (1976) (per curiam). For a recent overview of the topic, see Symposium on Campaign Finance Reform, 94 COLUM. L. REV. 1125 (1994).

${ }^{276}$ This kind of charge is sometimes levelled at Israel, whose interests are said to be asserted directly in Congress through American lobbying organizations. See, e.g., David K. Shipler, On Middle East Policy, A Major Influence, N.Y. TIMES, July 6, 1987, at 1 (stating that the American Israel Affairs Committee Organization "has gained the power to influence a Presidential candidate's choice of staff, to block practically any arms sale to an Arab country and to serve as a catalyst for intimate military relations between the Pentagon and the Israeli Army"); Jacob Weisberg, The Lobby with a Lock on Congress, NEWSWEER, Oct. 19, 1987, at 46 (stating that the American Israel Public Affairs Committee "has developed a touch so soft that members of Congress now hardly realize they are being lobbied" and that "sometimes the organization doesn't have to lobby at all").

277 See Abrams, supra note 45; Kathryn Abrams, Relationships of Representation in Voting Rights Act Jurisprudence, 71 TEX. L. REV. 1409 (1993). In the following discussion I have 
groups in electing representatives is misguided because electoral success is a "misleadingly simple measure of political effectiveness." ${ }^{278} \mathrm{Citi}-$ zens' political goals "are accomplished not simply by pulling a lever, but by engaging in activities such as discussion, lobbying, and coalitionbuilding with others. ${ }^{279}$ These opportunities to influence the outcome of the political process occur throughout an extended and continuous process, ranging from preelection engagement in political dialogue and attempts to persuade other voters, through post-election attempts to influence the outcome of the legislative process. ${ }^{280}$

Unlike Mill, however, Abrams believes that our system of government is already structured to provide these numerous and adequate opportunities for political influence. Consequently, her analysis is geared toward supporting denial-of-influence claims rather than claims of inadequate influence. Abrams's beliefs about the ways in which our system in fact distributes political influence dictate the kinds of denial-ofinfluence claims her theory would support. Abrams's theory should not, for example, consider the right to vote to be denied by the mere failure to provide proportional representation (or some similar kind of electoral success) to minority groups. Rather, the right to vote should be denied in her system, only if groups or individuals are also shut out of pre-voting and post-voting processes.

These assumptions are borne out in Abrams's conception of the right to vote, which is both broader and narrower than Mill's. It is broader in that it encompasses a right "to participate in all of the predicate activities that precede and follow the vote." ${ }^{.281}$ Thus, the right to vote is broad enough to encompass, for example, the rights to speak, to

categorized Abrams as relying primarily on a theory of protective democracy. To be fair, there is a strand in her work that, in its reliance on the dialogic and community-building nature of politics, has a distinct flavor of deliberative democracy. See, e.g., Abrams, supra note 45 , at $475-76,489 \mathrm{n} .217$ (suggesting that legislative reform may make taking a role in self-government and political change more valuable to members of the minority community, thus increasing "the investigation or clarification of shared objects," a goal that Abrams views "as indisputably deliberative"). However, the deliberative democracy aspects of Abrams's writings seem to do relatively little substantive work-that is, they do not much seem to influence her conclusions. Put another way, Abrams's substantive conception of the right to vote would not change much if she relied solely on the protective benefits of political participation and ignored what she occasionally treats as the deliberative or dialogic benefits of participation. Indeed, Abrams herself notes that "[i]t does not appear... that Congress considered the benefits of direct political participation in passing either the Voting Rights Act or the 1982 amendments." Id. at 476 n.173.

${ }^{278}$ Abrams, supra note 45, at 452.

${ }^{279}$ Id. at 452-53.

${ }^{280}$ See id. at 47475,480 .

${ }^{231} \mathrm{Id}$. at 504. 
associate with others for political purposes, and to lobby government officials. ${ }^{282}$ On the other hand, Abrams's conception of the right to vote is also narrower than Mill's in that it need not include the kind of right to electoral success implicit in an entitlement to proportional representation. Merely "being outnumbered" in an American-style winner-takeall district, Abrams contends, "is not a cause for complaint" so long as the minority may from time to time "successfully assert its influence" on elections or policies-for example, "by coalescing with others" in the district. $^{283}$

\section{c. Guinier: Influence in a Racially Polarized Society}

Another assumption critical to Mill's conception of the right to vote is that persuasion in the legislative chamber is both possible and effective. Yet in a legislature representing a highly polarized society, attempts to persuade the opposition may be futile. Moreover, even when persuasion is possible, it must not occur so incrementally or over such a long period that its protective potential becomes meaningless. When a majority threatens immediately to invade irreparably some fundamental right of the minority, the possibility of persuading the majority to reverse itself at some time in the distant future is small consolation.

Lani Guinier takes as her basic premise the complete failure of this critical Millian assumption. ${ }^{284}$ At the core of Guinier's work is a forceful critique of the notion that having a voice in legislative decisionmaking meaningfully protects the rights and interests of minorities. Guinier sees contemporary American society as deeply divided along racial lines, with each group so entrenched in its positions that Millian dialogue and persuasion is highly unlikely, and perhaps impossible. ${ }^{285}$ Under these circumstances, representation alone accomplishes little; it merely shifts the venue of exclusion from the electorate to the legisla-

282 See id. at 480 . These particular rights already receive significant constitutional protection, of course, under the First Amendment. See e,g., McDonald v. Smith, 472 U.S. 479, 482 (1985) (noting that the First Amendment guarantees "that people 'may communicate their will' through direct petitions to the legislature and government officials" (quoting 1 ANNALS OF CONGRESS 738 (1789))); Buckley v. Valeo, 424 U.S. 1 (1976) (per curiam) (stating that the First Amendment protects political expression, including expressions in the form of campaign contributions).

${ }^{28 s}$ Abrams, supra note 45, at 506.

${ }^{234}$ In the following discussion, I rely primarily on GUINIER, TYRANNY, supra note 29. Her most recent writings may reflect additional evolution in some aspects of her views. See, e.g., Guinier, [E]racing supra note 33; Guinier, More Democracy, supra note 45.

${ }^{285}$ See, e.g., GuINIER, TYRANNY, supra note 29, at 3, 9, 34, 37, 60, 70, 103. 
ture. $^{286}$

Guinier is impatient with those who advocate proportional minority representation on communitarian grounds. To be sure, she is sympathetic to the possibility that some black Americans derive "psychological value" from the election of "similarly situated representatives, ${ }^{287}$ and recognizes that this kind of representation might "fulfill the black community's need for self-affirmation through 'role models." ${ }^{288}$ Nonetheless, Guinier, at bottom, believes this point of view excessively romantic, ${ }^{289}$ and its advocates blind to the fact that the store is being plundered on the legislative floor. ${ }^{250}$ What counts for Guinier is bottom-line protection of minority rights and interests, and so long as racial minorities are consistently out-voted where it counts-in the legislature itself-minority presence in the legislature is mere "tokenism." For Guinier, then, representation protects rights and interests only when it results in political action that conforms to the preferences of the represented. The substance of the decision counts far more than the process by which it was reached. Consequently, the point of reference against which Guinier constantly orients herself is the "transformative social agenda" of the original civil rights movement. ${ }^{2.2}$

Unlike Abrams, who conceives of the right to vote as stopping short of the right to elect a chosen representative, and Mill, who believes that the right to proportional representation exhausts the right to vote, Guinier contends that the right to direct legislative representation is the minimum that an effective right to vote entails. For Guinier, the right to vote embraces guarantees of interest representation within the legislature itself," including, in the right circumstances, "imposition of internal remedial constraints on the decisional process." ${ }^{204}$ These might include modifying the legislative process to include cumulative voting or supermajority requirements. ${ }^{203}$ Guinier's most extreme suggestion seems to be that various groups be given the opportunity to

${ }^{286}$ See id. at 61-69.

287 Id. at 55.

${ }^{288} I d$. at 56 .

${ }^{289}$ See id. at 42 (asserting that the reigning theory of black electoral success "romanticizes black elected officials as empowerment role models").

${ }^{200}$ See id. at 58, 61-65.

${ }^{201} I d$ at 41 .

${ }^{202}$ Id. at $44-48,69$.

293 See id. at 101-14.

294 $I$. at 106 .

203 See id. at 107-08. 
"take turns" at setting the substance of government policy, ${ }^{296}$ a suggestion that apparently involves discarding altogether the assumption that the purpose of politics is to discover or decide upon the content of a single common good and to direct society toward its achievement. ${ }^{297}$

During the controversy over her nomination to be Assistant Attorney General for Civil Rights, Guinier was widely attacked for advancing radical, controversial views about democracy. ${ }^{298}$ This criticism is misguided; if Guinier's views are controversial, it is for a very different reason. What leads Guinier to her conception of the right to vote is not a unique or revolutionary view of the nature and purpose of democracy, but a set of empirical beliefs about the ways in which citizens in the contemporary United States actually exercise political influence. For Guinier, political influence is for the most part exercised, to put it bluntly, by a white, largely racist majority that manipulates electoral processes to perpetuate its power and then rams its policies through the legislative process without any input from, and if necessary over the objections of, a racial minority. ${ }^{2 \times y}$ Under these circumstances, protective democracy is hard-pressed to provide much protection for minority rights and liberties without an extremely robust conception of voting rights.

Despite some occasional disclaimers, ${ }^{300}$ Guinier seems, for the most part, to contend that the existing framework of government, properly understood in the ways she describes, presently entitles minorities to the kinds of changes she advocates. She makes such a claim possible by approaching the Voting Rights Act at a very high level of abstraction, characterizing its purpose as the achievement of "political empowerment" and "political fairness" through the recognition of "group voting rights." ${ }^{301}$ She then argues that the prevailing interpretation of the Act

See id at 2-7.

207 This assumption goes back in Western thought at least as far as the ancient Greeks. See, e.g., ARISTOTLE, supra note 248, at 1278b, 1279 b (emphasizing the common good of the citizenry as the proper aim of government). Professor Richard Briffault also notes the impracticability of some of Guinier's suggestions. See Briffault, supra note 31, at 465 (noting that cumulative voting and supermajority requirements do not guarantee legislative results).

${ }^{213}$ Good summaries of the controversy can be found in Stephen L. Carter, Foreword to GUINIER, TYRANNY, supra note 29, at vii-xx, and in Pamela S. Karlan, Democracy and DisAppointment, 93 MICH. L. REV. 1273, 1289-96 (1995).

${ }^{299}$ See, e.g., GUINIER, TYRANNY, supra note 29, at 9-10, 63, 103, 118.

${ }^{300}$ See, e.g., id. at 109 (characterizing her purpose as "primarily aspirational"); id. at 73 (characterizing her proposed remedies as "a heuristic to demonstrate the potential unfairness" of some voting systems).

sol Id. at 92-93. 
is incapable of achieving these statutory purposes, ${ }^{302}$ and that only by reinterpreting it in the way she proposes can the Act be made to fulfill its own goals. ${ }^{303}$

This is a classic example of a denial-of-influence claim. Guinier's argument is that our existing system of government allocates a certain level of political influence to groups and individuals, but that this influence has been denied in practice to racial minorities by a combination of racial polarization and the use of electoral mechanisms that diminish the influence of political minorities.

\section{B. The Disattractions of Protective Democracy Claims}

The foregoing discussion reveals at least two aspects of protective democracy-based voting rights claims that might make them unattractive to the Supreme Court. First, the resolution of protective democracy-based claims would require the Court to make firm decisions about the degree of political influence to which citizens are entitled under the Constitution, something it is loath to do. Second, there is a distinct possibility that if the Court were to overcome its reluctance to engage these issues and undertake the task of expounding the constitutional structure of political influence, the outcome might well be highly unsatisfying according to contemporary standards of democracy-so much so that the Court may wish to avoid the subject altogether.

${ }^{\text {s02 }}$ See id. at 77-91.

${ }^{\text {sos }}$ A more direct route to the same result is to argue that the Constitution is concerned with both race and democracy, but that the achievement of racial justice takes priority over the maintenance of strictly democratic institutions. Some scholars have taken positions along these lines. See, e.g., Karlan, Undoing the Right Thing, supra note 29, at 40 ("A government's interest in strict majoritarianism and its own preferred electoral forms are trumped by what section 2 identifies as a more compelling, immediate concern-political opportunity for minority voters."); see also Alan Howard \& Bruce Howard, The Dilemma of the Voting Rights Act-Recognizing the Emerging Political Equality Norm, 83 CoLUM. L. REv. 1615 (1983) (arguing that constitutional interests in democracy and racial equality are in conflict and that ways should be found to accommodate both). For a direct argument in favor of prioritizing concerns for democracy over racial concerns, see Butler, supra note 37, at 357-62.

Guinier, however, has for the most part tried to avoid justifying her voting rights claims predominantly on racial grounds, anchoring them instead on arguments about democratic processes. She seems quite correct when she argues that her solutions will help everyone, not just racial minorities. See, e.g., GUINIER, TYRANNY, supra note 29, at 149 (cumulative voting will "give more voters, not just racial minorities, the opportunity to vote for a winning candidate"); see also Arthur Eisenberg, The Millian Thoughts of Lani Guinier, 21 N.Y.U. REV. L. \& SOC. CHANGE 617, 626 (1994) (book review) (“[Guinier] labors to fashion a system that is fairer to all who hold minority viewpoints regardless of race or ethnicity."). 


\section{Reluctance to Commit to a Constitutional Structure of Political Influence}

We have seen that in both inadequate influence claims and denialof-influence claims, plaintiffs argue that the Constitution requires American political institutions to take forms that provide citizens with specific avenues by which to obtain particular levels of political influence over government officials. The unavoidable logic of a protective democracy-based voting rights claim thus compels a court to decide specific details of the constitutional structure of political influence. These are just the kinds of questions that the Supreme Court has historically been reluctant to decide.

The Court's reluctance is based primarily on doubts about its competence to resolve the kinds of questions posed by protective democracy claims, and consequent questions about the appropriate limits of the judicial role. For example, the most significant manifestation of the Court's reluctance in this area is undoubtedly its refusal to construe the Guarantee Clause. ${ }^{304}$ This clause, which commits the United States to assuring the states a "republican" form of government, is one of the likeliest constitutional sources for protective democracy rights against states and localities. ${ }^{305}$ The very notion of republican government presupposes a system of representation subject to some degree of popular electoral control over the representatives. As Justice Douglas once observed, "the right to vote is inherent in the republican form of government envisaged by Article IV, Section 4 of the Constitution. ${ }^{306}$ As we have seen, however, elections by themselves do not necessarily implement meaningful popular control-who votes, for what, and under what circumstances are critically important factors. ${ }^{307}$ Consequently, the meaning of the guarantee cannot be determined without making at

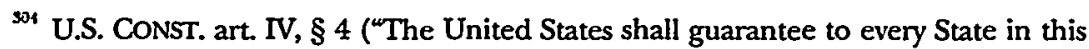
Union a Republican Form of Government....").

${ }^{303}$ See ELY, supra note 177 , at $118 \mathrm{n} . *$ (noting that the right to vote "is most naturally assignable to the Republican Form Clause"); see also Akhil Reed Amar, The Central Meaning of Republican Government: Popular Sovereignty, Majority Rule, and the Denominator Problem, 65 U. COLO. L. REV. 749, 762-66 (1994) (arguing that the core value protected by the clause is popular sovereignty as embodied in majority rule); Adam H. Kurland, The Guarantee Clause as a Basis for Federal Prosecutions of State and Local Officials, 62 S. CAL. L. REV. $369,415-70$ (1989) (arguing that the clause can be a source of power for the prosecution of official corruption at all levels of government); Deborah Jones Merritt, The Guarantee Clause and State Autonomy: Federalism for a Third Century, 88 COLUM. L. REV. 1, 25-26 (1988) (arguing that the clause limits the ability of states to restrict popular representation).

${ }_{506}$ Baker v. Carr, 369 U.S. 186, 242 (1962) (Douglas, J., concurring).

sot See supra Part III.A.l. 
least some minimal judgments about the efficacy of particular democratic institutions.

Nevertheless, for nearly 150 years the Court has held the Guarantee Clause nonjusticiable. In Luther v. Borden, decided in 1849, the Court held that resolution of a conflict between two groups, each claiming to be the legitimate government of Rhode Island, raised a political question under the Guarantee Clause which the Court was powerless to decide. ${ }^{308}$ The Court has since adhered fairly consistently to the position that Guarantee Clause issues are nonjusticable. ${ }^{30}$

Another aspect of the Court's reticence is exemplified by its wariness in entering what it has called, in Justice Frankfurter's well-known phrase, the "political thicket." ${ }^{310}$ In his dissent in Baker v. Carr, ${ }^{311}$ Justice Frankfurter went on to argue that the federal courts should not be in the business of "choos[ing] among competing theories of political philosophy" for the purpose of deciding "an appropriate frame of government" for the states. ${ }^{312}$ Although Justice Frankfurter's position has never captured a majority of the Court, his message has nevertheless had a lasting impact in the form of heightened judicial caution. ${ }^{313}$ For

${ }^{308} 48$ U.S. 1,46 (1849).

${ }^{303}$ See, e.g., Pacific States Tel. \& Tel. Co. v. Oregon, 223 U.S. 118, 150-51 (1912) (holding nonjusticable a Guarantee Clause challenge to a state constitutional amendment); Colegrove v. Green, 328 U.S. 549, 556 (1946) (holding nonjusticable a Guarantee Clause challenge to state apportionment); Baker, 369 U.S. at 208-10 (reaffirming in dicta that cases brought under the Guarantee Clause are nonjusticable). But see Minor v. Happersett, 88 U.S. (21 Wall.) 162, 175-76 (1874) (refusing to recognize suffrage rights for women under the Guarantee Clause); New York v. United States, 505 U.S. 144, 183-85 (1992) (noting the disagreement as to whether the Guarantee Clause implicates nonjusticable political questions and concluding that " $[w]$ e need not resolve this difficult question today").

The Court's position has been forcefully criticized. See, e.g., ELY, supra note 177, at $118 \mathrm{n}$ ** (criticizing the Court's subsequent generalization of Luther to hold that all invocations of claims under the clause as "rooted in a category mistake" and "a gross mistake of logic"); Erwin Chemerinsky, Cases Under the Guarantee Clause Should Be Justiciable, 65 U. COLO. L. REV. 849, 852 (1994) ("[I]t is time for the Guarantee Clause to be resurrected and given a meaningful role in contemporary constitutional law."); Merritt, supra note 305 , at $70-78$.

${ }^{310}$ Colegrove, 328 U.S. at 556.

s11 369 U.S. 186 (1962).

312 Id. at 300 (Frankfurter, J., dissenting).

${ }^{313}$ The present spokesperson for the Frankfurter view is Justice Thomas. See Holder v. Hall, 114 S. Ct. 2581, 2596 (1994) (Thomas, J., concurring) ("[M] atters of political theory are beyond the ordinary sphere of federal judges. And that is precisely the point. The matters the Court has set out to resolve in vote dilution cases are questions of political philosophy, not questions of law.").

This contemporary reticence to confront problems of "political theory" seems especially strange in light of the much older judicial tradition of directly grappling with issues 
example, in Gaffney v. Cummings, ${ }^{314}$ the Court declined to hold that minor deviations from strict mathematical equality among state legislative districts made out a prima facie case of unconstitutional malapportionment. The Court's prior forays into the political thicket, it said, did not commit it to getting "bogged down in a vast, intractable apportionment slough.. ${ }^{315}$

\section{Lack of a Constitutional Right to Vote}

If the Court generally prefers to avoid committing itself on constitutional issues of political structure, there is a second, more specific reason why it might prefer not to consider the substance of protective democracy claims: the answers might prove unpleasant. Although the Court's habitual reluctance to elucidate the constitutional structure of political influence complicates the analysis, there are good grounds for interpreting what little the Court has said to mean that the United States Constitution provides its citizens with no significant mandatory level of political influence through voting. ${ }^{316}$ In other words, the Constitution does not contain any substantive right to vote. The Framers'

of political theory. See, e.g., McCulloch v. Maryland, 17 U.S. (4 Wheat) 316, 404-22 (1819); Chisholm v. Georgia, 2 U.S. 419, 421 (1793). This is especially true given the Court's ready superimposition of a political theory on the First Amendment, under which the right to free speech is deemed a right of political influence. See, e.g., New York Times Co. v. Sullivan, 376 U.S. 254 (1964). Moreover, Justice Thomas's disclaimers seem disingenuous in light of the fact that he obviously has a political theory of the Constitution, one that is narrower than the theories underlying the vote dilution cases and the Voting Rights Act. See Guinier, [E]racing, supra note 33, at 121-22 (arguing that Justice Thomas's theory of the political structure of the Constitution is one in which it grants universal suffrage and nothing more); Bierstein, supra note 37, at 1519 (noting that in Holder, 'Thomas treated 'political theory' as if it were a dangerous animal, to be avoided at all costs.... It never seemed to occur to Thomas that the Constitution and the Voting Rights Act represent political theory choices, which it is then the Court's obligation to interpret and enforce").

s11 412 U.S. 735 (1973).

${ }^{315}$ Id. at 750. Justice Frankfurter's admonition has also affected individual Justices on individual occasions. For example, Justice Stevens invoked Frankfurter's warning to justify his concurrence in Mobile v. Bolden, 446 U.S. 55, 93 (1980) (Stevens, J., concurring). Justice Stevens argued that an otherwise valid state or local decision to employ a multimember district could not be invalidated merely because some decision makers supported it for improper reasons. To adopt such an approach, he said, would "entangle the judiciary in a voracious political thicket." Id.

${ }^{3 I 6}$ In contrast, the Court has held that the Constitution does provide citizens with a mandatory level of political influence through speaking: the First Amendment almost uniformly prohibits government censorship of speech designed to support a political position. See, e.g., Buckley v. Valeo, 424 U.S. 1 (1976) (per curiam); Monitor Patriot Co. v. Roy, 401 U.S. 265 (1971) (finding that a newspaper's allegation of a candidate's past criminal conduct is relevant to a candidate's fitness for office). 
suspicion of popular democracy combined with their willingness to compromise on issues of federal structure may have undermined any possibility that the Constitution implements a regime of meaningful protective democracy. ${ }^{317}$

\section{a. The Minimal Guarantee of Republican Government}

A useful place to begin to get the flavor of the constitutional treatment of political rights is the Guarantee Clause. I have said that this provision is the most obvious source for the kinds of rights that would make protective democracy meaningful. Suppose the Court relaxed its unwillingness to construe the clause. What protections might it provide? The answer is, in all likelihood, not much.

According to Madison, a government is a "republic" when it "derives all its power directly or indirectly from the great body of the people, and is administered by persons holding their offices during pleasure, for a limited period, or during good behavior." ${ }^{318}$ Further,

[i]t is essential to such a government that it be derived from the great body of the society, not from an inconsiderable proportion, or a favored class of it .... It is sufficient for such a government that the persons ad$\underset{319}{\operatorname{ministering}}$ it be appointed, either directly or indirectly, by the people ....

While this definition sounds promising, it delivers less than it seems. After giving this definition of republican government, Madison goes on to show how the proposed national government is acceptably republican even though only one house of one branch of the proposed government, the House of Representatives, is popularly elected. The Senate, President and judiciary do not make the United States inadequately republican because they are selected indirectly by the people-through the state legislatures, the electoral college, and the joint presidential and senatorial confirmation process. ${ }^{320}$ Indeed, Madison's definition would not be offended even if no government officials at all were elected directly by the people.

${ }^{317}$ I wish to stress that the following account is not one with which I agree. Although I find the Court's conclusions to flow plausibly from its assumptions, I believe those conclusions to rest on a methodology of constitutional interpretation that is excessively formal in its originalism. See James A. Gardner, The Positivist Foundations of Originalism: An Account and Critique, 71 B.U. L. REV. 1 (1991). A full account of my reasons for disagreeing with the Court are beyond the scope of this Article.

${ }^{318}$ THE FEDERALIST NO. 39 (James Madison).

${ }^{319}$ Id.

${ }^{320}$ See id. 
Obviously, this is a conception of republican government far narrower than the contemporary view, which has gravitated toward preferences for direct popular election of as many significant officials as possible. On the federal level, the Seventeenth Amendment has instituted direct popular election of Senators, ${ }^{321}$ and the electoral college has collapsed into a close approximation of direct popular election. ${ }^{322}$ On the state level, not only are many judges elected, ${ }^{323}$ but so are many executive branch officials like comptrollers and attorneys general. ${ }^{324}$

The Guarantee Clause, then, seems to require very little in the way of opportunities for the direct exercise of protective democracy. Although states are apparently free to provide more opportunities for selfprotection through democratic institutions than the clause requires, they need not provide much if they so choose. But what of the distribution of the franchise? Suppose a state chooses, as all have done, to provide more protective democracy than the Guarantee Clause requires. Does the clause at least require the state to distribute the franchise as widely as possible? Again, the answer seems to be negative.

Although Madison's language-he speaks, for example, of the "great body of society"-suggests that the franchise must be widely available in a government that counts as republican, this impression is misleading. In an effort to calm anxieties, Madison took the position in The Federalist No. 43 that the existing forms of state governments would necessarily meet the test of the Guarantee Clause. A century later, the Court echoed Madison's reasoning in Minor $v$. Happersett, ${ }^{325}$ an 1874 challenge to a state law prohibiting women from voting. The Court ruled that although the plaintiff was a citizen, the Constitution did not require that all citizens be made voters. The heart of the Court's ruling was its conclusion that no provision of the Constitution could have been intended to require states to grant the franchise more broadly than did any of the original states at the time of ratification. ${ }^{326}$ As women were uniformly disenfranchised by the original states, they could not claim a constitutional right to vote. ${ }^{327}$

${ }^{321}$ U.S. CONST. amend. XVII.

${ }^{322}$ See infra Part III.C.2.

s2s See THE COUNCIL OF STATE GOVERNMENTS, 31 THE BOOK OF THE STATES 1996, at 133-35 tbl.4.4.

S24 See id at $35-36$ tbl.2.10.

${ }^{325} 88$ U.S. 162 (1874).

${ }_{220}$ See id. at $171-77$.

927 The same presumably would have been true of blacks until ratification of the Fifteenth Amendment in 1870, and remains true of poor white males so long as the relevant property test is not imposed in the form of a tax. See U.S. CONST. amend. XXIV. 
Although not based on the Guarantee Clause, many contemporary Court decisions nonetheless reflect a similar understanding of the Constitution as setting an extremely minimal threshold of political rights. The Court has held, for example, that nothing in the Constitution requires a state's chief executive to be popularly elected. ${ }^{328}$ It has also declined to construe the Constitution to require states to structure local governments in any particular way, ${ }^{329}$ and has suggested that there is no constitutional right to be governed by elected rather than appointed local government officials. ${ }^{330}$

\section{b. The Allocation of Voting Rights to the States}

If the Guarantee Clause proves unaccommodating to protective democracy-based claims, might a constitutional right to vote exist elsewhere in the document? The Court has, after all, often spoken of such a right. ${ }^{391}$ Again, the answer, in the Court's view, seems to be that there is no such right.

The seeds of this conclusion are found in some of the Court's unfortunately rather offhand attempts to reconcile its most contradictory statements about the right to vote. As noted earlier, the Court has at times made apparently diametrically opposed statements about the right to vote: it has said both that the Constitution protects the right to vote in state and federal elections, and that there is no substantive constitutional right to vote for any state or federal office. ${ }^{332}$ The Court has occasionally tried to reconcile these statements in the following way. It is correct, the Court has indicated, to say that the Constitution confers on no individual a substantive right to vote. The Equal Protection Clause, however, requires that individuals be permitted to participate in

${ }^{923}$ See Fortson v. Morris, 385 U.S. 231 (1966).

${ }^{329}$ The leading case is still Hunter v. City of Pittsburgh, 207 U.S. 161, 178-79 (1907) (holding that states have absolute discretion over the structure and nature of their municipal corporations).

${ }^{\text {sso }}$ See Sailors v. Board of Educ., 387 U.S. 105, 110-11 (1967) (holding that no election was required for the county's school board members); see also Rosenthal v. Board of Educ., 385 F. Supp. 223 (E.D.N.Y. 1974) (3-judge court) (per curiam), affd 420 U.S. 985 (1975) (holding that the area's school board need not be popularly elected); Pirincin v. Board of Elections, 368 F. Supp. 64 (N.D. Ohio 1973) (3-judge court) (same); Egan v. Wisconsin State Bd., 332 F. Supp. 964 (E.D. Wis. 1971) (3-judge court) (same); Wallis v. Blue, 263 F. Supp. 965 (N.D. Ga. 1967) (3-judge court) (holding that state constitutional procedures for a grand jury selection of school board members did not violate the Equal Protection Clause).

${ }^{391}$ See, e.g., Reynolds v. Sims, 377 U.S. 533, 555 (1964) (noting that the "right to vote freely for the candidate of one's choice is of the essence of a democratic society").

s32 See supra notes 8-12 and accompanying text. 
elections "on an equal basis with other qualified voters whenever the State has adopted an elective process for determining who will represent any segment of the State's population. ${ }^{\text {s33 }}$ In other words, the Constitution does not require states to grant the right to vote to anyone; consequently, there is no constitutional right to vote. The Constitution thus requires the creation of no institutions of protective democracy at all. Should a state choose to go beyond this minimum requirement, however, it must do so consistent with principles of equal protection.

Although the Court has never elaborated on this reading of the Constitution, ${ }^{934}$ the reading finds some support in the constitutional text. Article I, Section 2 provides: "The House of Representatives shall be composed of Members chosen every second Year by the People of the several States, and the Electors in each State shall have the Qualifications requisite for Electors of the most numerous Branch of the State Legislature." ${ }^{395}$ The Seventeenth Amendment applies the same language to the election of senators. ${ }^{396}$ These two provisions operate to extend the franchise in federal elections to those citizens in each state who are qualified under state law to vote for members of the state Assembly. ${ }^{397}$ Thus, the Constitution seems to place explicitly and exclusively in the hands of the states decisions about the distribution of the right to vote in congressional elections. Moreover, Article II provides for presidential election by electors, who are to be appointed in each state "in such Manner as the Legislature thereof may direct." gives states even greater control over voter qualifications in presidential elections in that the state need not provide at all for popular election of

sss San Antonio Indep. Sch. Dist. v. Rodriguez, 411 U.S. 1, 35 n.78 (1973); accord Dunn v. Blumstein, 405 U.S. 330, 336 (1972) (" [A] citizen has a constitutionally protected right to participate in elections on an equal basis with other citizens in the jurisdiction.").

${ }^{34}$ The closest the Court has come to directly expounding this kind of theory is probably its discussion in Minor v. Happersett, 88 U.S. (2I Wall.) 162, 170-71 (1874), of why the right to vote is not a privilege or immunity of United States citizenship within the meaning of the Privileges and Immunities Clause of the Fourteenth Amendment. See U.S. CONST. amend. XIV, $\$ 1$.

sss U.S. CONST. art. I, $\$ 2$.

${ }^{936}$ See id. at amend. XVII, $§ 1$ ("The electors in each State shall have the qualifications requisite for electors of the most numerous branch of the State legislatures.").

${ }^{357}$ Every state except Nebraska, which has a unicameral legislature, has a bicameral legislature composed of an Assembly or House of Representatives, and a smaller Senate. See THE COUNCIL OF STATE GOVERNMENTS, supra note 323, at 63 tbl.3.1.

${ }^{353}$ U.S. CONST. art. II, $\S 1$. The states have broad latitude in deciding upon methods to select electors. See McPherson v. Blacker, 146 U.S. 1, 35 (1892) ("[T] he appointment and mode of appointment of electors belong exclusively to the States."). 
presidential electors. ${ }^{399}$

Taken together, these provisions suggest that the United States Constitution commits wholly to the states decisions about who may vote in federal elections, and that the document therefore provides United States citizens with no substantive right to vote whatsoever. ${ }^{340}$ The implications of this reading of the Constitution are significant, for it follows that a state so inclined could constitutionally disable its citizens from voting for any federal office by eliminating popular election of presidential electors, and by reducing to zero the number of its citizens eligible to vote for members of the state Assembly. ${ }^{341}$ Of course, the price would be steep: the state would forfeit its representation in the House of Representatives, ${ }^{342}$ and such measures would almost certainly be unpopular. On this reading of the Constitution, however, it would be legal. ${ }^{343}$ Moreover, even if eliminating popular elections for the state assembly would violate what minimal protections the Guarantee Clause might provide, the Court's application of the political question doctrine

${ }^{\text {s99 }}$ During the early history of the United States, in many states presidential electors were selected by the state legislatures rather than by popular vote. See McPherson, 146 U.S. at 29 (noting that in the first presidential election, this method was followed in Connecticut, Delaware, Georgia, New Jersey and South Carolina).

${ }^{340}$ This conclusion is entirely consistent with the substantial body of case law holding that Congress has extensive powers to regulate federal elections. See, e.g., United States v. Classic, 313 U.S. 299 (1941); Burroughs v. United States, 290 U.S. 534 (1934); United States v. Mosley, 238 U.S. 383 (1915); In re Coy, 127 U.S. 731 (1888); Ex Parte Siebold, 100 U.S. 371 (1879). Just because Congress has the power to provide a larger dose of protective democracy than the Constitution minimally requires does not raise an inference that the Constitution sets these minima at any particular point. Indeed, any inference might run more strongly in the other direction. See Lowenstein, supra note 191, at 73.

${ }^{941}$ This was essentially Justice Harlan's position. See Reynolds v. Sims, 377 U.S. 533, 593-614 (1964) (Harlan, J., dissenting).

${ }^{s+2}$ The Fourteenth Amendment provides:

when the right to vote at any election for the choice of electors for President and Vice President of the United States, Representatives in Congress, the Executive and Judicial officers of a State, or the members of the Legislature thereof, is denied to any of the male inhabitants of such State, being twentyone years of age, and citizens of the United States, or in any way abridged ... the basis of representation therein shall be reduced in the proportion which the number of such male citizens shall bear to the whole number of male citizens twenty-one years of age in such State.

U.S. CONST. amend. XIV, $§ 2$ (1868). For a discussion of the history and significance of this section, see Richardson v. Ramire, 418 U.S. 24, $41-53$ (1974) and Reynolds, 377 U.S. at 593-608 (Harlan, J., dissenting).

${ }^{343}$ But see Michael J. Perry, Modern Equal Protection: A Conceptualization and Appraisal 79 COLUM. L. REV. 1023, 1079 (1979) (arguing that it is "wholly unnecessary for the Court to declare that there is a constitutional right to vote in state elections because the existence of the franchise as a political-moral right is unquestioned," and no state "would even dream of abolishing the franchise"). 
would preclude judicial enforcement of the guarantee.

\section{c. Voting as a Tertiary Form of Protection}

These conclusions about the lack of a constitutional right to vote seem strange to the modern legal mind. How is it possible for the Framers to have embraced notions of protective democracy yet to have created a plan of government that affords the people so little actual opportunity to protect themselves democratically? In fact, this situation posed no contradiction for the Framers. Despite the modern Court's rhetoric about the importance of the right to vote, for the Framers, voting in the United States actually played a comparatively minor role in the protection of fundamental rights from government encroachment. Consequently, judicial recognition of a substantive constitutional right to vote might well have seemed to them unnecessary.

For reasons discussed earlier, ${ }^{344}$ there can be little doubt that a primary purpose of the founding generation was to create a constitutional scheme of governance that would secure the fundamental rights of the American people against invasion by the newly created national government. Indeed, this was of such great concern to the Framers that they created three mutually supporting mechanisms designed to achieve this end: separation of powers, a bill of rights, and direct election of Representatives.

The separation of powers-including the vertical separation effected by federalism-protects liberty by dividing governmental power, and then providing officials within each power center with "the necessary constitutional means and personal motives to resist encroachments of the others." ${ }^{345}$ This struggle disables government officials from amassing the kind of power necessary to create a tyranny. ${ }^{346}$ The Bill of Rights protects the fundamental liberties of the people even more directly, by explicitly identifying the protected rights and prohibiting their abridgment by the government. When enforced by an independent judiciary, this kind of restraint becomes quite potent. Finally, voting protects fundamental rights by allowing the people to make sure that elective government offices are occupied by individuals who are unlikely to turn on the people and invade their rights.

s44 See supra Part I.A.

343 THE FEDERALIST NO. 51 (James Madison).

${ }^{36}$ THE FEDERALIST NO. 47 (James Madison) ("The accumulation of all powers, legislative, executive, and judiciary, in the same hands, whether of one, a few, or many, and whether hereditary, self-appointed, or elective, may justly be pronounced the very definition of tyranny."). 
The Constitution thus creates a form of government that is protective-but it is less clear that the form of government so created is a protective democracy in the sense in which the term is usually meant. The theory of protective democracy that we inherited from English political thought ${ }^{347}$ was devised to justify popular control over a government in which the legislature was supreme, and in which the legislative and executive branches were not clearly distinct. ${ }^{348}$ In a government lacking a written bill of rights or a sharp separation of powers, the right to vote is critically important because it is virtually the only effective way to restrain government power.

In the United States, on the other hand, voting may be far less important than theories of protective democracy suggest. First, the fundamental rights that voters might otherwise seek to protect at the polls already receive direct, substantive protection under the Bill of Rights and other constitutional provisions, reducing the urgency of electoral supervision. ${ }^{349}$ Second, the systems of horizontal and vertical separation of powers-checks and balances and federalism-substantially reduce the threat to those rights posed by the government in the first place. Under such a scheme of governance, voting is at the very least reduced to only one of several methods for protecting liberty, and it may well be the least important one. The Framers unequivocally believed that democracy is not a form of government in which the rights of the citizens are likely to be respected. ${ }^{350}$ For these reasons, the lack of a constitutionally mandatory right to vote seems, if not less troubling, then at least less puzzling.

\section{d. Where Does the Right to Vote Come From?}

Taking the position that the Constitution contains no substantive right to vote in federal elections has obviously made the Court extremely uncomfortable, and it has strained in many cases to limit the destructive potential inherent in such a narrow construction of the

${ }^{347}$ See supra Part I.A.; see also Gardner, supra note 62, at 200-13 (arguing that the Constitution is based on "a Lockean theory of popular sovereignty").

${ }^{348}$ For example, the British Prime Minister and Cabinet Ministers are all sitting members of Parliament.

${ }^{349}$ See Alexander, supra note 177, at 574 ("Our version of democracy combines substantive and procedural conceptions. The substantive conception is reflected in the various constitutional rights that trump pure majoritarianism and in the institution of judicial review that enforces those rights and rules. It is not reflected in a concern for the demography of electoral districts.").

${ }^{350}$ The most notable expression of this view is THE FEDERALIST NO. 10 (James Madison). 
right. For example, the Court has held that Congress has the power under Section 5 of the Fourteenth Amendment to override state decisions and confer eligibility to vote in federal elections when necessary to enforce the Equal Protection Clause. ${ }^{351}$ More importantly, the Court has created a bizarre equal protection doctrine under which the right to vote, a right that in the Court's view lacks any substantive constitutional protection, is nevertheless considered fundamental for equal protection purposes, thereby requiring strict judicial scrutiny of laws distributing the franchise. ${ }^{352}$ The idea of according full-blown fundamental-right treatment under the Equal Protection Clause to a right concededly offered no substantive constitutional protection has been roundly criticized, even by friends of the Court's results. ${ }^{353}$

What has led the Court to this point? How can a powerful right to vote materialize from nowhere? Explanations will be easier to come by if we first consider the features of communitarian democracy that have made it attractive to the Court in many voting rights cases.

\section{The Attractions of Communitarian Democracy Claims \\ 1. The Logic of Communitarian Democracy-Based Voting Rights Claims}

Communitarian democracy is about exclusion: according to this theory, people want the vote because its possession signals the possessor's status as a full member of society. Voting rights claims based on communitarian democracy are thus framed independently of any questions concerning governmental structure and political influence. Instead, the claimant says, in effect: "Voting is a pivotal social practice that defines full membership in this society. As a full member of this society, I must be afforded the opportunity to vote."

This formulation embraces three separate subclaims. First, the claimant asserts that voting ${ }^{354}$ is an essential emblem of full membership in society. Second, the claimant asserts that he or she is, or is entitled

${ }^{551}$ See Oregon v. Mitchell, 400 U.S. 112 (1970).

${ }^{332}$ See, e.g., Reynolds v. Sims, 377 U.S. 533 (1964); Kramer v. Union Free Sch. Dist. No. 15, 395 U.S. 621 (1969).

${ }^{353}$ See, e.g., Perry, supra note 343, at 1078; Ira C. Lupu, Untangling the Strands of the Fourteenth Amendment, 77 MICH. L. REv. 981 (1979). The Court has since moved toward recognizing rights as fundamental only when they can be found in the constitutional text. See San Antonio Indep. Sch. Dist. v. Rodriguez, 411 U.S. 1, 33-36 (1973).

${ }^{334}$ Or any other identified practice; such claims need not be limited to voting. See infra Part IV.B. 
to be treated as, a full member of society and therefore entitled to join in the society's socially central activities. Finally, the claimant asserts that his or her exclusion from participation in the identified activity is wrongful.

Against what standards are such claims to be evaluated? Clearly, communitarian claims are based on something more than the law itself. They are not merely legal claims, but social claims, and they consequently appeal broadly to societal self-understanding. The communitarian-based claim is a claim about the kind of society we have: here are the things we do that are significant, and here are the kinds of people we include in these activities. Legal and constitutional standards are by no means irrelevant; they are important constitutive elements of any society's self-understanding. ${ }^{355}$ Yet they hardly exhaust such understandings, which may draw on a host of extralegal social or political customs and conventions.

One significant source of these customs and conventions, which overlaps to a great extent with any community's self-understanding, is its traditions. Consequently, the resolution of communitarian democracy-based voting rights claims should take into account American democratic traditions, broadly defined. Moreover, in light of the specific assumptions implicit in communitarian democracy claims, relevant traditions would certainly include traditional American understandings of the rights and privileges of citizenship as well as traditional understandings of eligibility for citizenship status.

\section{The Appeal of American Democratic Traditions}

Because we tend to think of tradition as conservative, we generally assume that its application to constitutional questions will yield politically and legally conservative results. This kind of constitutional adjudication is sometimes criticized as unduly protective of an unfair status quo. ${ }^{356}$ It comes as a pleasant surprise, then, that traditional American understandings of democracy are far more progressive than the standards written into the Constitution. As we have seen, the Constitution is understood to contain no substantive right to vote and to implement

355 See, e.g., KARST, supra note 61; SANFORD LEVINSON, CONSTITUTIONAL FATTH (1988); JAMES BOYD WHITE, HERACLES' BOW (1985); Robert A. Burt, Constitutional Law and the Teaching of the Parables, 93 YALE L.J. 455 (1984); James A. Gardner, The Failed Discourse of State Constitutionalism, 90 MICH. L. REV. 761, 768-70, 815-16 (1991); Paul W. Kahn, Community in Contemporary Constitutional Theory, 99 YALE L.J. 1 (1989).

${ }^{356}$ See, e.g., SUNSTEIN, supra note 45 (arguing that the use of common law traditions as a constitutional baseline preserves an unjust status quo). 
no significant mandatory regime of protective democracy. In sharp contrast, American tradition has from the nation's birth been far more inclusive, protective and generally democratic than the Constitution itself.

One of the earliest manifestations of a tension between the constitutional scheme and popular American beliefs about democracy was the almost immediate collapse of the electoral college. ${ }^{357}$ Intended to be a body of wise and virtuous citizens exercising independent judgment, ${ }^{358}$ it quickly devolved into a reliable conduit for the implementation, as nearly as possible within constitutional constraints, of a form of direct presidential election. ${ }^{359}$ A similar fate ultimately befell the constitutional method for selecting senators. Originally, senators were to be selected by state legislatures exercising the same kind of independent judgment expected of the electoral college. ${ }^{350}$ Yet the public soon began to influence senatorial selections through the use of party nominating conventions and direct senatorial primaries, ${ }^{361}$ and popular dissatisfaction with the performance of state legislatures eventually led to the institution of direct senatorial election upon ratification of the Seventeenth Amendment. ${ }^{362}$

Another tension between traditional and constitutional standards of democracy has been the constant pressure exerted by the former on the latter for expansion of the franchise. The Fifteenth, Nineteenth, Twenty-fourth and Twenty-sixth Amendments expanded the franchise to preclude exclusions based on race, sex, payment of taxes and age, respectively. ${ }^{363}$ These amendments reflect social understandings of a connection between voting and citizenship far stronger than that formally implemented by the Constitution. ${ }^{364}$

Many of these tensions have been reflected in parallel develop-

${ }^{357}$ See U.S. CONST. art. II, $\$ 1$ and amend. XII.

338 See, e.g., THE FEDERALIST No. 68 (Alexander Hamilton).

339 In Justice Jackson's scathing words: "This arrangement miscarried. Electors, although often personally eminent, independent, and respectable, officially become voluntary party lackeys and intellectual nonentities .... As an institution the Electoral College suffered atrophy almost indistinguishable from rigor mortis." Ray v. Blair, 343 U.S. 214, 232 (1952) (Jackson, J., dissenting).

${ }^{360}$ See U.S. CONST. art. I, $\$ 3$.

sol See Terry Smith, Rediscovering the Sovereignty of the People: The Case for Senate Districts, 75 N.C. L. REV. 1, 36-37 (1996).

${ }^{362}$ For an account of the factors underlying passage of the Seventeenth Amendment, see HOEBEKE, supra note 110, at 189-95.

see S.S. CONST, amends. XV, XIX, XXIV, XXVI.

${ }^{\text {sot }}$ See Minor v. Happersett, 88 U.S. (21 Wall.) 162, 171 (1874) (ruling that voting is not a privilege or immunity of citizenship within the meaning of the Constitution). 
ments in the evolution of political parties. Almost entirely unforeseen by the Framers, the growth of political parties has had a significant impact on the democratization of American politics; indeed, in his classic study of the party system, the political scientist E.E. Schattschneider declared flatly that "political parties created democracy and ... modern democracy is unthinkable save in terms of the parties." ${ }^{365}$ Political parties have not only made formal politics more democratic, ${ }^{366}$ but have become internally more democratic over time. ${ }^{367}$

Finally, American democratic traditions today include well over a century of congressional enactments implementing standards of fair elections and good government that greatly surpass any constitutionally established minima. These include laws prohibiting violence and intimidation at elections, ${ }^{368}$ minimizing duress in the voting process by prohibiting certain uses of political patronage, ${ }^{369}$ prohibiting the disenfranchisement of racial and language minorities, ${ }^{370}$ and regulating the giving and accepting of money in federal election campaigns. ${ }^{371}$

Theories of communitarian democracy are well-placed to take advantage of these comparatively progressive understandings of American citizenship and its relation to voting. Unlike protective democracy, which relies heavily on the constitutional creation of officially sanctioned means of political influence, communitarian democracy relies on societal understandings and traditions that need not be firmly bound to the constitutional text.

\section{Tradition as an Object of Interpretation}

Another feature of communitarian democracy's reliance on tradition that might make it attractive to courts is the broadly interpretive

${ }^{365}$ E.E. SCHATTSCHNEIDER, PARTY GOVERNMENT 1 (1942).

${ }^{366}$ Schattschneider makes the bold claim that political parties act extralegally in powerful ways. They "control the decisions of public authorities at the points at which the law cannot control them." Id. at 11-12. This allows parties "to compel public officers to behave in ways that the law does not contemplate, by methods of which the law is ignorant, without in any way affecting the validity of their official acts." Id. at 12.

${ }^{367}$ See V.O. KEY JR., POLTICS, PARTIES, AND PRESSURE GROUPS 396-98 (5th ed. 1964) (tracing the development of national primary system).

363 Among the earliest enactments were the Enforcement Act, ch. 114, 16 Stat. 140 (1870); the Force Act, ch. 99, 16 Stat. 433 (1871); and the Ku Klux Act, ch. 22, 17 Stat. 13 (1871).

${ }^{363}$ See Hatch Act, ch. 368, 43 Stat. 1053, 1070 (1925).

${ }^{370}$ See Voting Rights Act, Pub. L. No. 89-110, 79 Stat. 437 (1965).

${ }^{371}$ See Federal Election Campaign Act, Pub. L. No. 92-225, 86 Stat. 3 (1971), amended by Pub. L. No. 93-442, 88 Stat. 1263 (1974). 
manner in which the relevant traditions are assessed. Protective democracy claims are claims about the actual ability of individuals and groups to use the political process to protect themselves and their interests. Resolution of this kind of claim can consequently be extremely complex and factually messy; a court may need to consider the relevant powers of the government body, the responsiveness of elected officials, the kinds of stimuli that evoke political responses, the reactions of potential coalition partners, and a host of other complex factorssomething, that is, like the "intensely local appraisal" that the Court spoke of in White $v$. Regester, ${ }^{372}$ or the kind of fact-bound analysis now required by section 2 of the Voting Rights Act. ${ }^{373}$

Communitarian democracy-based claims, in contrast, are measured against community understandings and socially constitutive traditions. Although the content of community understandings and traditions could easily be the subject of formal evidentiary fact-finding, the Court typically has reached conclusions in this area by a far more rough-andready process, one that tends more to the openly interpretive than the aspirationally objective. ${ }^{374}$ Because eyeballed interpretations of tradition are easier and cleaner than the kind of functional evaluations of government power and citizen influence that protective democracy analysis would require, courts may prefer communitarian democracy as a path of least resistance.

A hint of these factors may be found in the line of decisions starting with Shaw v. Reno. ${ }^{375}$ In Shaw and its progeny, the Court struck down several state redistricting plans on the ground that the legislatures were guided in their line-drawing predominantly by racial considerations, and that the plans were unconstitutional racial gerrymanders. ${ }^{376}$

Because the plaintiffs in these cases complained not of diminished or inadequate political influence, but of a racial affront, the majority opinions quite properly treated the plaintiffs' claims as communitarian. This characterization, however, allowed the Court to deal with the is-

${ }^{372} 412$ U.S. 755, 769 (1973).

${ }^{373}$ See Thornburg v. Gingles, 478 U.S. 30 (1986). As Samuel Issacharoff has pointed out, aspects of the Voting Rights Act "forced the judiciary to confront the actual operation of challenged electoral systems." Issacharoff, supra note 227, at 1836.

374 The Court tends to treat the content of traditions and community understandings as "constitutional facts," to be found by general knowledge, rather than "facts" to be found through evidence. See Bose Corp. v. Consumers Union, 466 U.S. 485, 508 n.27 (1984); Henry P. Monaghan, Constitutional Fact Review, 85 COLUM. L. REV. 229 (1985).

509 U.S. 630 (1993) (Shaw I).

${ }^{376}$ See id.; Miller v. Johnson, 115 S. Ct. 2475, 2488 (1995); Shaw v. Hunt, 116 S. Ct. 1894 (1996) (Shaw II); Bush v. Vera, 116 S. Ct. 1941 (1996). 
sues at a level that was comfortably conceptual. Thus, the majority opinions dealt with broad definitions of the nature of cognizable harms arising from gerrymandering, ${ }^{377}$ or the kinds of reasons that a state might legitimately offer to justify race-based districting. ${ }^{378}$

Justice Stevens's dissent in Shaw $I{ }^{379}$ for example, presents an instructive contrast. Writing for himself and two other dissenters, Justice Stevens treated the underlying issue as one of protective democracy. The Voting Rights Act, he argued, was designed to improve the political effectiveness of racial minorities, ${ }^{380}$ a notion consistent with theories of protective democracy. Stevens expressed considerable skepticism about the possible communitarian basis of the plaintiffs' claim, condemning "speculative judicial suppositions about the societal message that is to be gleaned from race-based districting."

This focus committed Justice Stevens to a much more fact-intensive analysis. He demanded that the plaintiffs show that "their political representatives are actually unlikely to provide effective representation, ${ }^{382}$ and that the legislature was in fact motivated by racial considerations. ${ }^{389}$ He went on to devote several pages of a lengthy opinion to an analysis of the motivations of the legislature, ${ }^{384}$ something the majority was able simply to infer as a result of its conceptual communitarian approach.

\section{The Court's Move to Equal Protection}

We have now identified several reasons why the Court might prefer communitarian democracy-based voting rights claims to protective democracy-based claims. How has this preference been implemented? The answer lies in the Court's turn to the Equal Protection Clause as the main vehicle for resolving denial-of-influence claims.

In his seminal article on the Fourteenth Amendment, Ira C. Lupu argues convincingly that the Warren Court turned to equal protection as a source of substantive rights because it could not feasibly rely on the doctrine of substantive due process, which had become discredited following the Lochner era. ${ }^{385}$ Lupu terms the consequences of this sleight-

\footnotetext{
${ }^{377}$ See Shaw I, 509 U.S. at 630; Miller, 115 S. Ct. at 2475.

${ }^{378}$ Shaw II, 116 S. Ct. at 1894; Bush, 116 S. Ct. at 1941.

${ }^{379}$ Shaw II, 116 S. Ct. at 1907 (Stevens, J., dissenting).

${ }^{330}$ See id. at 1908.

${ }^{381}$ Id. at 1910.

ss2 Id. at 1911 (emphasis added).

sss See id. at 1912-13.

sst See id. at 1914-16.

${ }^{385}$ See Lupu, supra note 353 , at 993-96.
} 
of-hand "lamentable" for voting rights jurisprudence because it caused the Court to take a set of rights that could plausibly be inferred from the constitutional structure and situate them in a constitutional provision that provided no clear limiting principles. ${ }^{386}$ Lupu's diagnosis rests at least partly on his belief that a substantial right to vote can be found in the Constitution, ${ }^{387}$ an entirely plausible conclusion that, as we have seen, was rejected squarely by the Court. The Court's turn to equal protection, however, has had another dramatic consequence: it has made the Court far more receptive to theories of communitarian democracy than it might otherwise have been.

Consider a typical denial-of-influence claim brought by plaintiffs relying on a theory of protective democracy. Substantive resolution of such a claim would require the Court to decide the level of political influence to which the plaintiffs are constitutionally entitled, something the Court evidently wishes to avoid. By moving to an equal protection analysis, the Court has required such plaintiffs to recast their claims. Instead of arguing that they have been denied a degree of substantive political influence guaranteed by the Constitution, plaintiffs must now find an object of comparison and argue that they have been granted less political influence than the comparison group or individual.

In several ways, the equal protection framework seems to require plaintiffs to assert what is, essentially, a theory of communitarian democracy. The heart of a communitarian democracy claim is the contention that the government has given the plaintiff less than it has given others, a claim with obvious similarities to a prima facie claim of unequal treatment under equal protection principles. Communitarian democracy claims also appeal to a powerful strand in equal protection doctrine that sees the Equal Protection Clause as intended primarily to prevent demeaning social exclusions. ${ }^{389}$ Nevertheless, there is a significant difference between the two: equal protection analysis is parasitic

${ }^{385}$ See id. at 1031-32.

387 See id. at 106470 .

ses Certainly the most offensive of these are slavery itself and its Jim Crow equivalent, segregation. See, e.g., Brown v. Board of Educ., 349 U.S. 294, 300 (1955). See generally Kenneth L. Karst, Foreword: Equal Citizenship Under the Fourteenth Amendment, 91 HARV. L. REV. 1 (1977) (arguing that the Fourteenth Amendment embodies a core value of equal citizenship). Nevertheless, the Equal Protection Clause contains another strand that corresponds more closely to theories of protective democracy. This view is probably best expressed in Justice Jackson's observation that "there is no more effective practical guaranty against arbitrary and unreasonable government than to require that the principles of law which officials would impose upon a minority must be imposed generally." Railway Express Agency v. New York, 336 U.S. 106, 112 (1949) (Jackson, J., concurring). 
upon substantive theories, whereas communitarian democracy is itself a substantive theory of right.

As numerous scholars have shown, the notion of equality cannot by itself provide a standard for judging the constitutionality of unequal treatment. What constitutes equal treatment can be decided only incidentally to the application of some substantive conception of rights or justice. ${ }^{389}$ This means that the logic of protective democracy claims cannot be avoided by moving from substantive standards of political influence to a norm of equality found in the Equal Protection Clause. The Court still must establish some kind of substantive baseline against which to measure the propriety of any challenged allocation of political influence. If such a baseline is not drawn from the Constitution, it must be drawn from elsewhere. The move to equal protection analysis invites plaintiffs to use as a baseline, not the degree of political influence the Constitution officially provides, but the degree of influence in fact held by others.

Yet this move to an equal protection analysis should not get the Court off the hook. To resolve a denial-of-influence claim cast in equal protection garb, the Court must first decide whether the amount of influence possessed by those to whom the plaintiffs compare themselves is a constitutionally relevant standard of comparison. Yet that question can be decided only by going back to the Constitution to determine what rights of political influence it grants. This, as many have noted, makes the equal protection analysis largely superfluous. ${ }^{390}$

The case law suggests that the Court has indeed been unable to avoid setting a baseline, but that the equal protection context has allowed the Court surreptitiously to import a theory of communitarian democracy as a substantive baseline for resolution of equal protection claims. The Court permits this to occur by, in essence, treating community understandings and traditions concerning the right to vote as presumptively entitled to legal recognition. ${ }^{391}$ The result is an adjudica-

ss9 See Westen, supra note 251, at 547; Laurence H. Tribe, The Puzzling Persistence of Process-Based Constitutional Theories, 89 YALE L.J. 1063, 1064 (1980); Lupu, supra note 353, at 985; Perry, supra note 343, at 1027; Karst, supra note 388, at 5-11; see also Howard \& Howard, supra note 303, at 1635; Baker v. Carr, 369 U.S. 186, 300-01 (1962) (Frankfurter, J., dissenting).

${ }^{300}$ See, e.g., Perry, supra note 343, at 1075-77; Westen, supra note 251, at 543.

${ }^{501}$ A good example is the Court's present inclination to treat a state's use of "traditional districting principles" as presumptively constitutional, even in the face of a direct claim that the use of traditional districting principles is exactly what causes illegal minority vote dilution. See, e.g., Miller v. Johnson, 115 S. Ct. 2475, 2489 (1995) (concluding that a state legislature's compliance with traditional districting principles 
tory baseline that floats with changing community understandings of voting and democracy.

The Court has achieved this result in two distinct ways. First, the Court has at times explicitly rejected original constitutional understandings as legitimate bases for making voting rights decisions, choosing instead to rely on more favorable protective democracy traditions. The clearest example of this is Harper $v$. Virginia Board of Elections, ${ }^{392}$ in which the Court struck down a state poll tax that was a prerequisite for voting. In a careful historical analysis of the role of property qualifications in colonial America, Justice Harlan argued in dissent that the Constitution could not be understood to condemn voting qualifications like the Virginia poll tax. ${ }^{393}$ Writing for the majority, Justice Douglas bluntly responded: "In determining what lines are unconstitutionally discriminatory, we have never been confined to historic notions of equality.... Notions of what constitutes equal treatment...do change." ${ }^{\text {s94 }}$ Of course, what Justice Douglas meant is not that notions of equality change, ${ }^{395}$ but rather that substantive notions of democracy change. The Court in Harper recognized this change by substituting for unsatisfying constitutional baselines of protective democracy an equal protection baseline consisting of a set of far more protective American democratic traditions. ${ }^{396}$ As the Court has become more conservative in both its politics and its methodology of constitutional interpretation, however, this direct strategy has become less attractive.

A second approach by which the Court has facilitated the emergence of a communitarian democracy standard is its turn to citizenship as an equal protection baseline. For example, in Holt Civic Club v. City of Tuscaloosa, ${ }^{397}$ a case considered earlier, ${ }^{398}$ residents of a suburb of Tuscaloosa, Alabama, complained of being subject to certain Tuscaloosa regulations without being. able to vote for the Tuscaloosa officials who made and enforced those regulations. The Court rejected the claim, essentially on the ground that the citizens of Holt were just thatcitizens of Holt, and not of Tuscaloosa. The same approach yielded a

may suffice to refute a claim of racial gerrymandering).

392383 U.S. 663 (1966).

S9s See id. at $684-85$ (Harlan, J., dissenting).

${ }^{394}$ Id. at 669 .

${ }^{395}$ According to Westen, the idea of equality has endured for so long precisely because it has no substantive content. See Westen, supra note 251, at 547-48.

${ }^{300}$ See Harper, 383 U.S. at 670.

${ }^{307} 439$ U.S. 60 (1978).

${ }^{s 28}$ See supra Part II.A.1. 
different result in Dunn v. Blumstein, ${ }^{399}$ a case in which the Court struck down a durational residency requirement that barred Tennessee residents from voting until they had lived in the state for one year. Although Tennessee did not consider its residents to be citizens for purposes of voting during their first year of residency, the Court held, in effect, that Tennessee lacked that option-its residents simply were citizens as far as the Equal Protection Clause was concerned, and could not therefore be denied the vote. ${ }^{400}$

The thrust of these cases is to establish for purposes of equal protection analysis a baseline conception of citizenship embracing both voting and residency. Yet it is clear from the Court's prior decisions that this is a conception of citizenship that has been allowed to float free from the moorings of constitutional standards. What happens when the Court adheres strictly to constitutional standards of citizenship is illustrated vividly by Minor $v$. Happersett, ${ }^{401}$ an 1874 challenge to a state law prohibiting women from voting. The Court ruled that although the plaintiff was a citizen within the meaning of the Constitution, the Constitution nevertheless did not require that all citizens be made voters. The Court held that no provision of the Constitution could have been intended to require states to grant the franchise more broadly than did any of the original states at the time of ratification. ${ }^{402}$ Since the original states disenfranchised women, women could constitutionally be denied the right to vote. ${ }^{403}$ This is a far stingier substantive conception of the right to vote than the one relied on by the Court in Holt and Dunn.

The move to citizenship as an equal protection baseline does not by itself create a bias toward communitarian democracy-based voting rights claims: citizenship can just as easily provide an appropriate substantive baseline for resolving protective democracy-based claims. But by drawing its substantive conceptions of citizenship from contemporary community understandings and traditions rather than constitutionally established standards, the Court has smuggled into the equal protection analysis an adjudicatory baseline that is particularly congenial to communitarian democracy-based claims.

S99 405 U.S. 330 (1972).

${ }^{400}$ See id. at 351-52.

40188 U.S. (21 Wall.) 162 (1874).

${ }^{402}$ See id. at 171-76.

${ }^{403}$ The same presumably would have been true of blacks until ratification of the Fifteenth Amendment in 1870, and remains true of poor white males so long as the relevant property test is not imposed in the form of a tax. See U.S. CONST. amend. XXIV. 


\section{THE FUTURE OF RIGHT-TO-REPRESENTATION CLAIMS}

I want to conclude by returning to the subject of right-torepresentation claims. As we saw earlier, these are complex claims that seek to expand the boundaries of the right to vote by defining it to include not merely enfranchisement and equal weighting of ballots, but an affirmative entitlement to representation. Right-to-representation claims arise primarily in racial and political gerrymandering cases under the Constitution and racial gerrymandering cases under the Voting Rights Act-the kinds of cases that have generated the greatest amount of public and academic controversy.

Right-to-representation claims typically rest on theories of protective democracy; their premise is that the only feasible way for citizens to achieve a level of political influence adequate to protect their rights and interests is to elect a representative of their choice. ${ }^{404}$ Yet the Court has been hostile to protective democracy-based voting rights claims, including right-to-representation claims. On the other hand, voting rights claims seem to get a friendlier judicial reception when they rest on communitarian theories of democracy. This raises the final question I shall deal with in this Article: whether it is possible to recast right-torepresentation claims as communitarian-based claims, thereby giving them a better chance for survival in future encounters with the Court.

This question can be broken down into two separate inquiries: first, is it even possible to base a right-to-representation claim on communitarian grounds; and second, can such claims be cast so as to appeal successfully to the Court's preferences? I conclude that right-torepresentation claims can be based on communitarian theories of democracy, but that in such a form they are likely to be too weak to appeal much to the Court.

\section{A. Electoral Failure as a Form of Exclusion}

Because communitarian theories of democracy stress exclusion, they are most potent when the exclusion at which they take aim is most extreme. Where voting is concerned, exclusion is obviously most severe in cases of complete disenfranchisement, and in such cases communitarian-based claims have had their greatest successes. Nevertheless, there is nothing intrinsic to communitarian-based theories of democracy that limits their applicability to cases of total exclusion from the franchise.

${ }^{404}$ See supra Part II.C. 
Suppose, for example, that I have the franchise and that I may, in the words of the Court, "register and vote without hindrance." ${ }^{405}$ Yet suppose that in election after election, I find myself voting for the losing candidate. Year after year, my district sends representatives to the Senate, to Congress, and to the state and county legislatures, yet the candidates I prefer inevitably lose. By itself, this might not be cause for concern. But suppose that when I look at my neighbors, I see something very different. My neighbors, it seems, often vote for a winnernot all the time, perhaps, but far more often than I. As a result, they have something that I lack: representatives-representatives in Congress, in the statehouse, in the county and town governments. My neighbors' views are heard and pressed at every level, and I cannot help wondering that if they have their representatives, why don't I have mine? Might I not legitimately think of myself as a second-class citizen? Full membership in society, I might say, means more than merely casting ballots; it means having someone in power looking out for one's interests. Consequently, I cannot think of myself as a member of this club if I am never on the winning side in any election contest, if I can never look at the legislative body claiming to represent me and see someone for whom I voted. ${ }^{406}$ There can be little doubt that many people experience repeated electoral defeat in precisely this way-as an alienating repudiation not merely of their views, but of themselves as persons. ${ }^{407}$

The key, then, to building a right-to-representation claim on a communitarian foundation is to redefine the way in which society measures full citizenship. One must claim that although having the vote is a necessary attribute of membership in American society, and thus not to be disparaged, it is nevertheless not the measure of full citi-

${ }^{405}$ Mobile v. Bolden, 446 U.S. 55, 55 (1980).

${ }^{406}$ This position is similar to what Rae has called "lot-regarding equality." Douglas Rae, Two Contradictory Ideas of (Political) Equality, 91 ETHICs 451, 452 (1981). The communitarian democracy version, however, seems more sophisticated in the sense that equality is sought for a purpose-namely, achieving the status of full citizenship. Rae's account of "lot-regarding equality" seems to view citizenship as a simple-minded desire for the things of others without regard to their significance, or in consideration of all things as equally significant. The possibility of anyone actually holding such a view seems slight.

${ }^{407}$ See, e.g., GUINIER, TYRANNY, supra note 29 , at $76-77$ (discussing how black students considered majority decisionmaking at predominantly white schools to be illegitimate because the process "shut them out"). Similarly, Davidson quotes Tom McCain, "one of the first blacks elected to office since Reconstruction in Edgefield County, South Carolina" as saying "[a] race of people who are excluded from public office will always be second class." QUIET REVOLUTION, supra note 46, at 16 (quoting Laughlin McDonald, The Voting Rights Act Is the Only Hope Against a Century of All-White Rule, 1981 CIVIL LIBERTIES 34. 
zenship. Full citizenship, the argument goes, requires more than the vote-it requires representation as well, and to be denied representation is to be excluded from the essence of American society.

\section{B. The Slippery Slope Problem}

This kind of expansion of the communitarian claim is both easy and risky. It is easy because communitarian theories of democracy are theories of community rather than democracy, of status rather than right. Such claims focus on the conditions necessary to achieve a sense of belonging without supplying any tools to make normative judgments about the society to which people seek to belong. No societal characteristic is ruled out so long as individuals are treated in a way that makes them feel like full members of society.

For this reason, the broadening move is also risky, because it puts us on a potentially steep slippery slope from which there is no obvious exit. Suppose I am granted on communitarian grounds, through redistricting or the elimination of at-large voting, some right to elect my "own" representative. Yet I cannot help noticing that other people's representatives somehow seem to get their legislative agendas enacted into law, whereas my representative's proposals are continually outvoted on the legislative floor. Can I possibly feel like a full member of this society under those circumstances? Furthermore, bills passed by the legislature must be signed into law by the President, Governor or County Executive. Everyone else seems to be on the winning side once in a while in the balloting for head of the executive branch, so I can hardly feel like a full member of society when my own candidates keep losing-I need more than my own legislative representative, I need my own executive, too. At some point these kinds of claims clearly go too far-but where is that point? As with any slippery slope problem, the difficulty comes in knowing where to draw the line.

Another problem with travelling down the slippery slope is that the further down we go, the more the communitarian claim begins to resemble a protective democracy claim, the very thing we wish by hypothesis to avoid. The risk lies in defining citizenship in protective democracy terms by claiming that the measure of a citizen is his or her ability to exercise some particular degree of influence over the political process. At this point, the communitarian claim collapses into the protective claim, effectively thwarting it. ${ }^{408}$

${ }^{103}$ Protective democracy claims can also travel down a slippery slope. I might argue that I cannot protect my rights without the vote; or without a representative for whom I 


\section{Line-Drawing as Interpreting Full Citizenship}

The key to exiting the slippery slope lies in recognizing that a communitarian claim of the type we have been discussing is a claim about the meaning of full membership in society. The validity of a communitarian claim thus depends upon the validity of the underlying interpretation of societal membership. Although it is possible to interpret societal membership in many ways and to base a claim of exclusion on such interpretations, not every interpretation is equally good. When an interpretation goes wrong, one may reject the claim in the only way possible: by denying its accuracy. "No, you are mistaken," one might say; "that is not what it means to be a full member of this society. Full members of this society are entitled to vote, but not to win," or "they are entitled to electoral success, but not legislative success," and so on.

To the extent that the Court's decisions respond to communitarian claims, its line-drawing inevitably rests on some interpretation of what it means to be a full member of American society. In its decisions, the Court has chosen to draw a relatively clear and well-defended line at the point of enfranchisement, subject to the one-person, one-vote rule. ${ }^{409}$ Thus, in the Court's view, full membership in American society entitles one to cast a ballot, and to have that ballot fully weighted in the ensuing count-nothing more.

This view of the matter should help clarify just how heavy a burden is carried by one who wishes to convince the Court, on communitarian democracy grounds, to recognize a right to representation. For although the Court's interpretation is not the only possible interpretation of the attributes of full American citizenship-and, to be sure, other interpretations have been advanced ${ }^{410}-$ it is nevertheless a highly plausi-

voted; or without the power to veto legislation which I dislike, etc. See THERnSTROM, supra note 227, at 4 (interpreting the Voting Rights Act to give blacks a right to protection from "action intended to minimize black power, once established, could not be easily contained"); Hartman, supra note 167, at 694 (stating that the Court's decision in Whitcomb is partially explained by fears of a slippery slope leading to dilution claims by "every identifiable losing side"); Issacharoff, supra note 37 , at 900 (stating that what is missing from the Court's jurisprudence is "some mediating principle that keeps self-conscious group identity from translating into a claim of entitlement"; without such a principle, the logic of Gingles "pushes the redistricting process toward a racial and ethnic spoils system").

${ }^{409}$ See supra Part II.

${ }^{40}$ See, e.g., Jamin B. Raskin, Legal Aliens, Local Citizens: The Historical Constitutional and Theoretical Meanings of Alien Suffrage, 141 U. PA. L. REV. 1391, 1417-41 (1993) (concluding that noncitizen suffrage does not offend constitutional principles); Gerald M. Rosberg, Aliens and Equal Protection: Why Not the Right to Vote?, 75 MICH. L. REV. 1092, 1135-36 (1977) (concluding that a denial of voting rights to resident aliens can only be justified 
ble interpretation that is unlikely to be easily dislodged.

Few Americans, I take it, would claim that one is less than fully a citizen of this nation unless one has one's "own" representative in the legislature. One of the main difficulties with taking such a position is that almost everyone has from time to time been in the position of having voted for a loser. ${ }^{41}$ To conceive of those who have backed a loser as second-class citizens pending a new election with a different outcome requires conceiving of citizenship as something that is constantly gained and lost, or perhaps passed around from one majority coalition to the next. While such a view of citizenship is imaginable, it does not seem to be our own. Because Americans prize citizenship so highly, they tend to view it as presumptively permanent and substantial, ${ }^{412}$ not something so flimsy and transient that it can come and go repeatedly in a resident's lifetime. For Americans, citizenship simply is not linked to success in the political arena.

To say this is not to deny that things may look different from the "outside." Those Americans who seem never to have their own representative may feel so alienated from society as to consider themselves second-class citizens. Their feelings are real, and their interpretation of citizenship sensible from their point of view. ${ }^{413}$ Indeed, it is inevitable in a society containing any kind of internal diversity that different groups will place different interpretations on such socially significant concepts as citizenship and democracy. ${ }^{414}$

by "some compelling state interest").

"11 This issue shows up in the difficult problems of nonrepresentation of white subgroups. See, e.g., United Jewish Organizations of Williamsburgh, Inc. v. Carey, 430 U.S. 144 (1977); THERNSTROM, supra note 227, at 226; Aleinikoff \& Issacharoff, supra note 37, at 601 (discussing use of whites as "filler people" to fill out designated majority-minority districts). If the scope of representation is understood to include state and local legislative bodies or nonlegislative officials at any level, it would be shocking to find someone who has been on the winning side in every contest.

112 The Fourteenth Amendment provides that persons born or naturalized in the United States are citizens. U.S. CoNST. amend. XIV, § I. The Court has recognized this principle to prohibit involuntary divestiture of citizenship. See Perez v. Brownell, 356 U.S. 44, 61 (1958); Trop v. Dulles, 356 U.S. 86, 93 (1958). Moreover, the Court held in Perez that voting in a foreign election could be a legitimate ground for divesting an American citizen of citizenship. See Peres, 356 U.S. at 60 . Clearly, the view behind such legislation is that voting in a foreign election is an act of societal affiliation equivalent to a renunciation of American citizenship. It is the voting, then, and not the winning, that disaffiliates the citizen.

${ }^{415}$ For a sensitive and provocative view of the need to take such feelings seriously, see generally Calhoun, supra note 233.

114 See W.B. Gallie, Essentially Contested Concepts, 56 PROC. ARISTOTELIAN SOC'Y 167, $183-87$ (1955-1956). See generally Robert M. Cover, The Supreme Count, 1982 TermForeword: Nomos and Narrative, 97 HARV. L. REV. 4 (1983). 
Yet the existence, and even the inevitability, of differing interpretations is not the same as equality among interpretations. One way to accommodate different opinions is to avoid choosing among them. ${ }^{415}$ Another way is to insist upon dialogue as a way to allow persuasion or facilitate mutual understanding. ${ }^{416}$ But when decisions about the exercise of social power must be made-as when the Supreme Court must construe the Constitution to decide a case-so too must a choice be made among competing interpretations. And the only way to choose is to sift through the various interpretations with. a willingness to pronounce some either mistaken or just too idiosyncratic to credit.

Particularly in the area of voting rights, but also in the field of racial discrimination generally, the Court has been quite willing to do exactly that-even if the cost is social controversy. ${ }^{417}$ For these reasons, it seems unlikely that the Court will recognize a right-to-representation claim any time soon, even if it is based on a theory of communitarian democracy.

\section{CONCLUSION}

Themes of liberty and community dominate the federal jurisprudence of voting rights in two competing theories of democracy, protective and communitarian. Voting rights litigants have created a rich, but confusing, stew of ideas by invoking these concepts in a wide variety of adjudicatory contexts. The courts have contributed to the confusion by often failing to distinguish between the two theories, or by speaking the language of one concept while acting according to the other. The most striking manifestation of this confusion is a pattern in which the Supreme Court speaks primarily a language of protective democracy, yet has proved itself largely hostile to voting rights claims premised on the very theory that has provided the Court with so much of its stock of language and concepts. Conversely, the Court has proven to be far more receptive to voting rights claims based on communitarian democracy notions of exclusion and citizenship.

The root cause of this divergence lies in the conceptual structure of

${ }^{115}$ See James A. Gardner, The Ambiguity of Legal Dreams: A Communitarian Defense of Judicial Restraint, 71 N.C. L. REV. 805 (1993).

${ }^{116}$ This is the position of deliberative democracy. See Gardner, supra note 45 , at 428 $30,437-42$.

${ }^{417}$ Among the Court's more controversial recent decisions dealing with race are Croson, Adarand, Shaw and Miller. See City of Richmond v. J.A. Croson Co., 488 U.S. 469 (1989); Adarand Constructors, Inc. v. Pena, 115 S. Ct. 2097 (1995); Shaw v. Reno, 113 S. Ct. 2816 (1993); Miller v. Johnson, 115 S. Ct. 2475 (1995). 
protective democracy: to resolve a claim of inadequate protection of liberty, the Court must decide just how much protection the Constitution provides. The Court has been largely unwilling to do this not only because of doubts about its competency, but also quite possibly because it does not wish to embark upon a path that might force it to conclude that the constitutionally mandatory level of citizen influence on the political process is extremely low.

The Court has avoided this course by refusing to extract a substantive right to vote from the constitutional text and structure. Instead, the Court has turned to the Equal Protection Clause for a model of relative protection of voting rights. By relying extensively on a mediating conception of citizenship drawn from community understandings and American democratic traditions, the Court has become far more receptive to voting rights claims based on theories of communitarian democracy. At the same time, its reliance on community understandings and traditions has allowed it to craft a voting rights jurisprudence that may well be significantly more progressive than the jurisprudence to which it might commit itself if it relied solely upon constitutional text and structure and the intentions of the Framers. The turn to equal protection and communitarian democracy, in other words, may be responsible for giving us Harper, Kramer and Reynolds in lieu of Minor $v$. Happersett.

Ultimately, it is the Court's apparent commitment to a particular mode of constitutional interpretation that puts it in this position. The Constitution creates a republican form of government, ${ }^{418}$ based on the belief that a republican government is the form most conducive to the protection of liberty and the stability of society. ${ }^{419}$ By its own terms, it guarantees a republican form of government to the states, ${ }^{420}$ and it refers in numerous places to the "right of citizens of the United States to vote." ${ }^{421}$ From such a document, it ought to be no trouble to infer the existence not only of a constitutional right to vote, but of a right to vote of considerable power.

Certainly there was a time when the Court was willing to make precisely these kinds of inferences. The most striking example is probably Burroughs $v$. United States, ${ }^{422}$ in which the Court upheld a federal statute

118 See THE FEDERALIST NO. 39 (James Madison).

${ }^{119}$ See THE FEDERALIST No. 10 (James Madison).

${ }^{200}$ See U.S. CONST. art. IV, $\S 4$ ("The United States shall guarantee to every state in this Union a Republican Form of Government ....").

121 Id. at amends. XV, XIX, XXIV, XXVI.

122290 U.S. 534 (1934). 
limiting campaign contributions by political committees to presidential candidates. ${ }^{423}$ The defendants, charged with violating the statute, contended that Congress lacked the power to regulate this aspect of presidential elections. ${ }^{44}$ They relied on Article II, Section 1, Clause 4, which seems rather plainly to limit congressional power over presidential elections to setting the date and time for choosing presidential electors. ${ }^{425}$ They then compared this language to the far broader language authorizing congressional regulation of elections to Congress, ${ }^{426}$ and argued that the comparison revealed a strict limitation on congressional power over presidential elections. This is about as plausible as a text-based argument can get, yet the Court squarely rejected it:

The President is vested with the executive power of the nation. The importance of his election and the vital character of its relationship to and effect upon the welfare and safety of the whole people cannot be too strongly stated. To say that Congress is without power to pass appropriate legislation to safeguard such an election from the improper use of money to influence the result is to deny to the nation in a vital particular the power of self protection. Congress, undoubtedly, possesses that power.

Thus, the Court held that Congress has the power to regulate presidential elections because it must-because such a power must exist in a republic. Indeed, in a similar case the Court pronounced it "a waste of time to seek for specific sources of the power to pass these laws." ${ }^{428}$ If the Court has been willing to make these kinds of inferences to find congressional power to assure the responsiveness of federal elections to the popular will, why may it not plausibly infer the existence of a right to vote so that the people need not rely on Congress to protect them?

Justices Frankfurter and Harlan, and now Justices Thomas and Scalia, have issued ominous warnings against the Court's entry into the realm of political theory. ${ }^{429}$ Yet political theory was the guiding princi-

${ }^{128}$ See id. at 54748 .

${ }^{424}$ See id at 544.

${ }^{125}$ See U.S. CONST. art. II, \$ 1, cl. 4 ("The Congress may determine the Time of chusing the Electors, and the Day on which they shall give their Votes; which Day shall be the same throughout the United States.").

${ }^{126}$ See $i d$. art. I, § 4, cl. 1 ("The Times, Places and Manner of holding Elections for Senators and Representatives, shall be prescribed in each State by the Legislature thereof; but the Congress may at any time by Law make or alter such Regulations, except as to the Places of chusing Senators.").

${ }^{127}$ Burroughs, 290 U.S. at 545.

${ }^{128}$ Ex Parte Yarbrough, 110 U.S. 651,666 (1884).

120 See generally Baker v. Carr, 369 U.S. 186, 286-97 (1962) (Frankfurter, J., dissenting); see also Holder v. Hall, 114 S. Ct. 2581, 2596 (1994) (Thomas, J., concurring); Reynolds v. 
ple in Burroughs, to say nothing of its role in guiding the outcome of such constitutionally canonical cases as McCulloch v. Maryland. ${ }^{430}$ Justices Thomas and Scalia seem to think that the Court lurches blindly when it takes up political theory. In truth, the Court seems more often to lurch blindly either because it lacks a coherent political theory, or because it allows such theories to penetrate its jurisprudence adventitiously, as in the case of communitarian democracy. The confusion surrounding the constitutional and statutory right to vote is unlikely to be resolved until the Court steels itself to face this fact.

Sims, 377 U.S. 533, 621-24 (1964) (Harlan, J., dissenting).

${ }^{400} 17$ U.S. (4 Wheat.) 316 (1819). Justice Marshall's notions of the political theory underlying the Constitution led him, for example, to conclude that the Constitution was made by the people of the United States and not the states, that it may be construed to contain implied powers and limitations upon state power, and that there must in general be some congruity between the powers exercised by a government and the polity to which it is responsive. See id.

The Court also has not shrunk from applying an overtly political theory of democratic self-government in its First Amendment holdings. See, e.g., New York Times Co.v. Sullivan, 376 U.S. 254, 269 (1964); Monitor Patriot Co. v. Roy, 401 U.S. 265, 272 (1971); see also J. Harvie Wilkinson, III, The Supreme Court, the Equal Protection Clause, and the Three Faces of Constitutional Equality, 61 VA. L. REV. 945, 961-963 (1975) (arguing that both equality and free speech aim to keep American political life fluid and to prevent selfperpetuation in power as both preserve viable political opposition in situations where self-limitation seems unlikely). 